\title{
Systematic studies in the eucalypts. 5. New taxa and combinations in Eucalyptus (Myrtaceae) in Western Australia
}

\author{
K.D. Hill \& L.A.S. Johnson
}

\begin{abstract}
Hill, K.D. E Johnson, L.A.S. (National Herbarium of New South Wales, Royal Botanic Gardens, Sydney NSW Australia 2000) 1991. Systematic studies in the eucalypts. 5. New taxa and combinations in Eucalyptus (Myrtaceae) in Western Australia. Telopea 4(4): 561-634. New taxa and combinations in Eucalyptus subgenus Symphyomyrtus section Bisectaria from Western Australia are presented (some species occur in adjacent regions of South Australia and the Northern Territory). New species described are Eucalyptus pruiniramis, E. blaxellii, E. vegrandis, E. suggrandis (with subsp. alipes), E. goniocarpa, E. tenera, E. tephroclada, E. depauperata, E. phylacis, E. misella, E. foliosa, E. argyphea, E. recta, E. balanopelex, E. rosacea, E. educta and E. lata. New subspecies are recognised in E. loxophleba Benth. (subsp. supralaevis and subsp. lissophloia), E. sargentii (subsp. fallens), E. angustissima F. Muell. (subsp. quaerenda), E. mannensis Boomsma (subsp. vespertina), E. goniantha Turcz. (subsp. notactites), E. kessellii Maiden \& Blakely (subsp. eugnosta), E. balladoniensis Brooker (subsp. sedens), E. leptopoda Benth. (subsp. arctata, subsp. subluta and subsp. elevata) and E. websteriana Maiden (subsp. norsemanica). Taxa changed in status are E. gratiae and E. semiglobosa. A new name is provided for E. occidentalis var. stenantha (E. aspratilis). Taxa discussed under new circumscription are E. spathulata Hook., E. eremophila (Diels) Maiden, E. synandra Crisp, E. websteriana Maiden and E. orbifolia F. Muell. Misapplication of the name E. goniantha is corrected.
\end{abstract}

\section{Introduction}

New taxa described here are a selection from many that we have defined during our current revision of the eucalypts. These are taxa occurring in Western Australia, although some have sister taxa in South Australia and the Northern Territory. Many of these taxa are treated as undescribed species or subspecies in the semi-popular account of south-western taxa by Brooker \& Kleinig (1990). The new taxa discussed both here and by Brooker \& Kleinig were delineated by us during a comprehensive revisionary study of the eucalypts, and were freely discussed with Ian Brooker in order to allow the treatment in Brooker \& Kleinig. A number of other new species from Western and South Australia have also been formally described by other workers (Brooker \& Kleinig 1990, Brooker \& Hopper 1991, Brooker \& collaborators, in prep.).

At this stage, Eucalyptus L'Hérit. will be used in the traditional sense. The species are not allocated alphabetic codes according to the system of Pryor \& Johnson (1971) since these are being revised. Species are treated in the order in which they occur in the revised classification being developed from that of Pryor \& Johnson.

Rare or threatened species are allocated conservation status codes according to the system of Briggs \& Leigh (1988).

We are both acquainted with all the new and related taxa in the field. 


\section{Terminology}

The term 'stemonophore' is used throughout as a more acceptable combination of Greek elements than the Latin-Greek hybrid 'staminophore' (after Johnson \& Briggs 1984).

The term 'calyptra' is used throughout in place of 'operculum' as traditionally used in Eucalyptus. The latter term has been used in Eucalyptus alone, whereas the former is the accepted term for the fused perianth structures occurring widely in Myrtaceae (Johnson \& Briggs 1984, following McVaugh 1968).

Bark is described as 'persistent' in cases where it is not regularly shed, and 'smooth' when regularly shedding. The former includes 'stringybark', 'box' and 'ironbark' among other types, and the latter covers the 'gum' barks.

\section{Nomenclature}

Names of subgenera, sections, series and subseries used by us are intentionally published in a system (PJ) devised by Pryor \& Johnson (1971) and external to the International Code of Botanical Nomenclature. This avoids the confusion created by formal recognition of 'series' and 'subseries' that were used by Maiden (1903-1933) in a loose and informal sense, and classifying according to particular organ sets rather than as taxa. Moreover, as explained previously by Pryor \& Johnson (1971), it allows for clear application of names and categories. Since it has a perfectly clear formalism of its own, the term 'extracodical', rather than 'informal', is appropriate.

As in lists recently privately distributed to some eucalypt workers, subseries names here differ from those used by Pryor \& Johnson in ending with '-osae'. This is because '-inae' previously used is a subtribal ending (International Code of Botanical Nomenclature, 1988, Art. 19.2).

Chippendale (1988) has followed the Pryor \& Johnson classification, but simplified it in recognising one infrageneric rank only (series). This has lost much of the information contained within the Pryor \& Johnson hierarchical system, and has also created considerable confusion at the rank of series by attempting to formalise Maiden's informal groupings.

Brooker \& Kleinig (1990) follow the PJ system in almost all areas.

\section{Subgenus Symphyomyrtus, section Bisectaria}

All species included here are part of subgenus Symphyomyrtus, section Bisectaria. This is the largest section of the largest subgenus in Eucalyptus, and is substantially Western Australian in distribution. The section is characterised by the deeply divided cotyledons, but is otherwise highly diverse. A number of distinctive and clearly defined series are recognisable within Bisectaria, and will be discussed in more detail in a future publication.

One distinct group comprising two sister series has already been discussed (Series Salubres and Annulatae, Johnson \& Hill 1991). Other groups will be revised by us in the future, and still others are under revision elsewhere. Species treated here are miscellaneous new taxa arising out of our revisionary studies. All taxa treated here have separate inner and outer calyptra, the outer (calycine) calyptra shedding early in bud development. 


\section{Series Accedentes}

Species 1 is placed in series Accedentes, which is defined by the combination: pith glands present; filaments regularly inflexed; anthers oblong, dorsifixed, versatile; seeds shallowly pitted, dorsally compressed.

\section{Eucalyptus pruiniramis L. Johnson $\mathcal{E} K$. Hill, sp. nov.}

Affinis $E$. accedenti sed characteribus sequentibus distinguitur: ramuli et alabastra etiam fructus glauci, alabastra et antherae etiam fructus majores.

Type: Western Australia: $2.5 \mathrm{~km} \mathrm{~W}$ of Midland Highway along turnoff $5.5 \mathrm{~km} \mathrm{~N}$ of Watheroo, K.D. Hill 370, L.A.S. Johnson, D.F. Blaxell \& M.I.H. Brooker, 26 Oct 1983 (holo NSW; iso AD, BRI, CANB, MEL, PERTH).

\section{[Eucalyptus sp. D of Brooker \& Kleinig (1990)]}

Tree to $7 \mathrm{~m}$, often several-stemmed. Bark persistent on lower trunk or smooth; rough bark fibrous to ribbony, smooth bark white or grey to pinkish orange, powdery. Branchlets pruinose. Juvenile leaves disjunct early, ovate to orbicular, to $6 \mathrm{~cm}$ long, $6 \mathrm{~cm}$ wide. Adult leaves dull, grey-green, disjunct, broad-lanceolate, $8-15 \mathrm{~cm}$ long, 11-25 mm wide; petiole $15-25 \mathrm{~mm}$ long; lateral veins regular, at $40-50^{\circ}$ to midrib. Inflorescences simple, axillary; umbellasters 7-11-flowered; peduncles flattened, 10-18 $\mathrm{mm}$ long, to $6 \mathrm{~mm}$ wide; pedicels 2-4 mm long. Buds ovoid to fusiform, glaucous, $14-$ $17 \mathrm{~mm}$ long, 6-7 mm diam.; calyptra conical, about as long as hypanthium or slightly shorter. Stamens all fertile; filaments regularly inflexed; anthers oblong, dorsifixed, versatile, dehiscing through parallel slits. Style tip in pit in calyptra. Fruits 4-locular, cup-shaped to cylindrical or obconical, 10-12 mm long, 8-10 mm diam.; calyptra and stemonophore scars flat; disc depressed; valves triangular, raised, tips rim-level or exserted. Seeds ovoid, dorsiventrally compressed, grey-brown, very shallowly pitted; hilum ventral.

Distinguished from E. accedens W. Fitzg. by the glaucous twigs, buds and fruits, and the larger buds, anthers and fruits.

DisTRIBUTION: Known only from scattered populations in a restricted area between Arrino and Mogumber (mainly Irwin District, into Drummond and Dale Districts). Figure 1.

ECOLOGY: An uncommon small to medium tree or mallee, on rather nutrient-deficient, shallow soils over laterite or sandstone. It appears to hybridise in places with E. accedens, which also occurs in this area.

Conservation Status: $2 \mathrm{~V}$-. Restricted and local in distribution, in an area which has suffered considerable agricultural disturbance.

The epithet is from the Latin pruina, rime or hoar-frost, and ramus, a branch, referring to the pruinose branchlets.

Selected specimens (from 7 examined): Western Australia ( $N$ to S): Arrino to Three Springs, Johnson W49, 11 Dec 1960 (NSW); 4.9 km N of Sykes Road, N of Mogumber, Brooker 8521, 23 Apr 1984 (CANB, NSW, PERTH).

E. accedens - E. pruiniramis intergrades: $7 \mathrm{~km} \mathrm{~N}$ of Burma Road, Brooker 8138a, 27 May 1983 (CANB, NSW, PERTH); $6.8 \mathrm{~km}$ SE of Arrino, Brooker 8734, 1 Nov 1984 (CANB, NSW, PERTH); $9 \mathrm{~km}$ NW of Three Springs, B. Briggs 7745, 7746, 7747 \& Johnson, 1 Oct 1984 (NSW).

\section{Series Loxophlebae}

Species 2 to 4 are placed in series Loxophlebae, which is defined by the combination: 


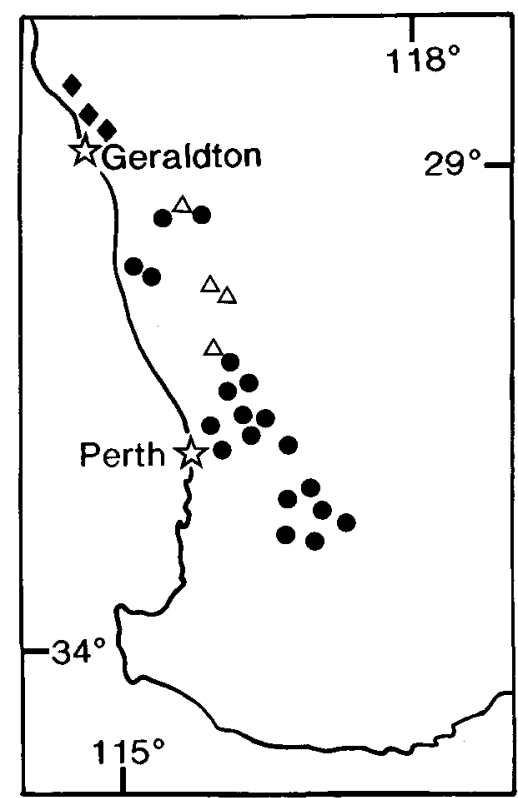

Figure 1. Distribution of E. pruiniramis $(\triangle)$, E. accedens $(\bullet)$ and E. blaxellii $(\bullet)$.

pith glands present; adult leaves glossy, with small stomata; filaments regularly inflexed, geniculate; anthers small, cuboid, dorsifixed (often attached very low on connective), versatile; seeds shallowly pitted, dorsiventrally compressed.

2. Eucalyptus blaxellii L. Johnson \& K. Hill, sp. nov.

Affinis E. loxophlebae sed characteribus sequentibus differt: folia juvenilia lanceolata vel late lanceolata nitentia nec glauca, venatione foliorum adultorum acuta minus irregulari. Habitus multicaulis plusminusve humilis ab eo formae sympatricae E. loxophleba differt.

TyPe: Western Australia: Howatharra Gap, N of Geraldton on Highway 1 ( $28^{\circ} 30^{\prime}$ S, $114^{\circ} 36^{\prime}$ E), D.F. Blaxell 1978, L.A.S. Johnson, M.I.H. Brooker E S.D. Hopper, 22 May 1983 (holo NSW; iso CANB, K, MEL, PERTH).

[Eucalyptus sp. I of Brooker \& Kleinig (1990)]

Mallee to $3 \mathrm{~m}$. Bark smooth, olive-brown to bronze. Juvenile leaves disjunct, semi-glossy to glossy, green, lanceolate to broad-lanceolate. Adult leaves disjunct, narrowlanceolate, acuminate, glossy, 6-9 $\mathrm{cm}$ long, 7-16 mm wide; petioles 5-9 $\mathrm{mm}$ long; lateral veins moderately spaced, at $20-40^{\circ}$ to midrib, irregular and partly broken, secondary reticulum irregular and broken; intramarginal vein distinct, $1.0-1.5 \mathrm{~mm}$ from margin. Inflorescences simple, axillary, umbellasters 7-flowered; peduncles terete or slightly angular, 3-6 mm long; pedicels slightly angular, 1-3 mm long. Mature buds ovoid-cylindrical, 7-8 mm long, 3-4 $\mathrm{mm}$ diam.; calyptra hemispherical, hypanthium 2-3 times longer than calyptra; filaments regularly inflexed, constricted (geniculate) at point of flexure; style constricted at base. Fruits cup-shaped to conical, 5-6 mm long, 4-6 mm diam., 4-5-locular; calyptra scar flat, c. $0.5 \mathrm{~mm}$ wide; disc vertically depressed, 1.0-1.5 mm wide; valves triangular, enclosed, held \pm horizontally. Seeds elliptic, grey- 
brown, shallowly reticulate, c. $1.5 \mathrm{~mm}$ long; hilum ventral; chaff smaller, paler. Figure 2.

This taxon is nearest the E. loxophleba group of taxa (including E. gratiae, discussed below). It is distinguished from that group by the lanceolate to broad-lanceolate, green juvenile leaves, the absence of pruinosity, the acute, not strongly irregular venation, and the mostly simple, axillary inflorescences.

DistRIBUTION: Known from two or three small populations in the Howatharra Gap area and north-east along the Moresby Range, from Geraldton to north of Northampton (Irwin District). Figure 1.

ECOLOGY: E. blaxellii occurs around breakaways in low sandstone hills, growing in mallee heath with a wide variety of scleromorphic shrub species.

Conservation status: 2E (Eucalyptus sp. 22, Briggs \& Leigh 1988, p. 119).

The specific epithet honours our colleague Donald F. Blaxell, Assistant Director (Living Collections) at the Royal Botanic Gardens, Sydney, who first noted the distinctive nature of this species in the course of his extensive field studies of the eucalypts.

Selected specimens (from 16 examined): Western Australia (N to S): Rob Road, $0.4 \mathrm{~km} \mathrm{~W}$ of Pt Gregory road, Brooker 9277, 8 May 1986 (CANB, NSW, PERTH); Nanson Road, Brooker 9193, 12 Mar 1985 (CANB, NSW, PERTH); 9 miles [14 km] NE of Geraldton on Yuna road, Chippendale 320, 16 Mar 1968 (CANB, NSW).

\section{Eucalyptus loxophleba Benth., Fl. Austral. 3: 252 (1867).}

Type Citation: 'W. Australia. Swan River and Darling range, Collie; Drummond, 2nd Coll. n. 82; York district, Preiss, n.246 (and 248?); Murchison river and Champion Bay, 'York Gum', Oldfield.'

Type: Western Australia: Swan River Colony, J. Drummond, 2nd collection, no. 82, 1843 (lecto K; isolecto BM, CGE, E, G, NSW, W). A fragment in NSW, which was a part of the K specimen, is annotated in Maiden's handwriting 'Drummond's 82 is the type.' This collection is here designated the lectotype.

$\equiv$ E. foecunda Schauer var. loxophleba (Benth.) Luehm. ex Maiden, Crit. Revis. Eucalyptus 1: 112, pl. 23, figs. 1-3; pl. 24 (1904).

Regarded as a variety of E. foecunda by Luehmann (1898) and Maiden (Crit. Revis. Eucalyptus 1: 112 (1904)), but again recognised as a species by Blakely (1934).

Tree to $15 \mathrm{~m}$ or mallee to $8 \mathrm{~m}$. Bark persistent to smaller branches or partly smooth, rough bark grey, shortly fibrous-flaky, smooth bark brownish, yellow-brown or greenish, smaller twigs glaucous. Juvenile leaves petiolate, ovate to orbicular, acute to rounded, dull, bluish, $8-13 \mathrm{~cm}$ long, 5-9 cm wide. Adult leaves glossy, lanceolate to broad-lanceolate, falcate, acute, 6-14 cm long, 10-25 mm wide; petioles 10-18 mm long; lateral veins at $10-30^{\circ}$ to midrib and highly irregular. Umbellasters axillary, 7flowered or often more, often clustered at leafless ends of small branches; peduncles 2-angled, 3-24 mm long; pedicels grooved, 2-5 mm long. Mature buds obovoid, 6-10 $\mathrm{mm}$ long, 3-4 mm diam.; calyptra shorter than hypanthium, hemispherical, rarely apiculate; filaments regularly inflexed, constricted (geniculate) at point of flexure; style constricted at base. Fruits conical, sometimes vaguely angular, 3-4-locular, 4-9 $\mathrm{mm}$ long, 4-6 mm diam.; disc narrow, flat; valves deeply sunken. Seeds dull, dark brown, cuboid, to $1 \mathrm{~mm}$ long; chaff similar, thinner, or linear, to $4 \mathrm{~mm}$ long.

Distinguished within the series by the combination: juvenile leaves ovate to orbicular, dull, bluish; adult leaves lanceolate to broad-lanceolate, glossy, venation acute, highly irregular; inflorescences aggregated onto short, leafless shoots. 


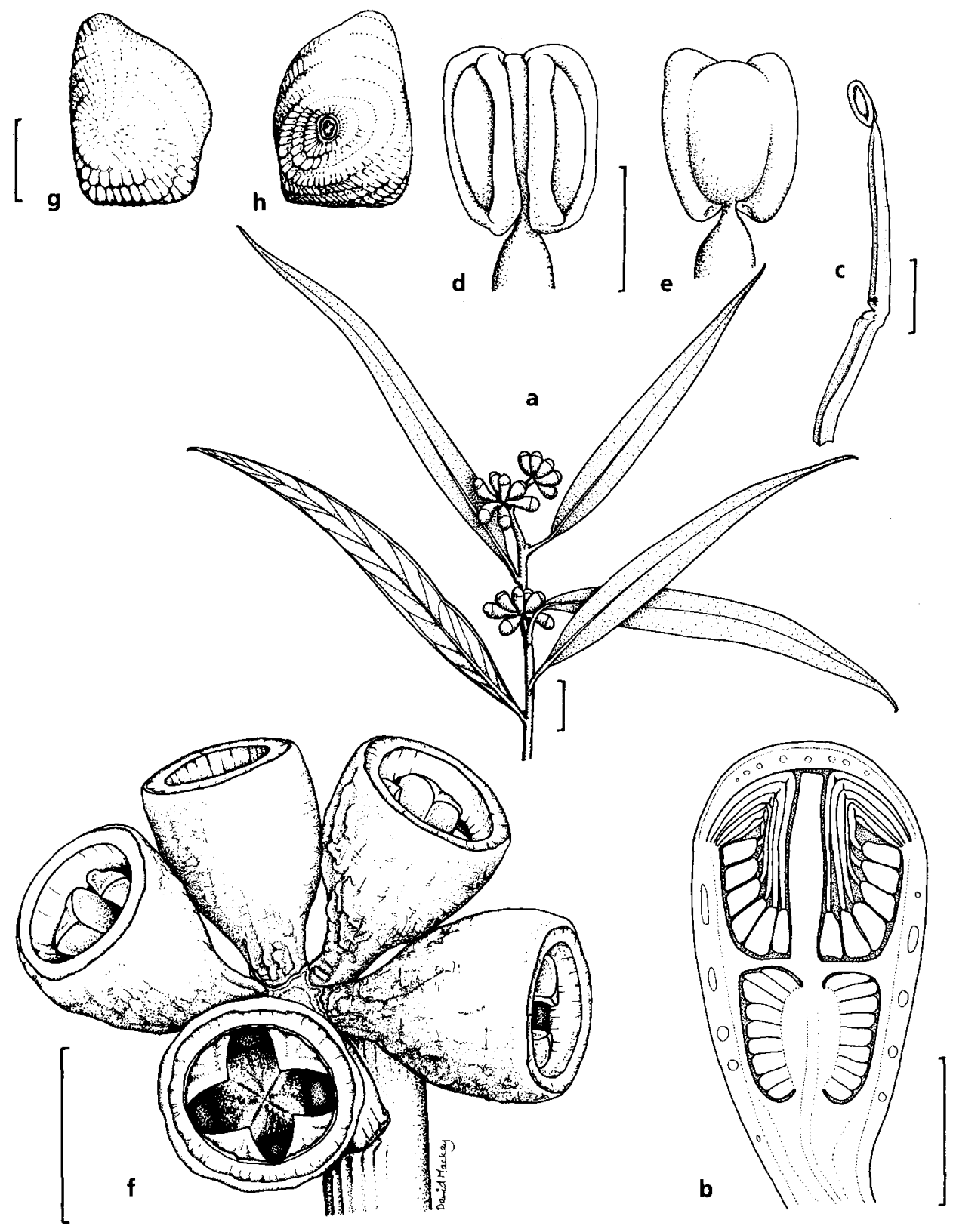

Figure 2. E. blaxellii. $\mathbf{a}$, adult leaves and buds; $\mathbf{b}$, section of bud; $\mathbf{c}$, filament showing flexure; $\mathbf{d}, \mathbf{e}$, anther; $\mathbf{f}$, fruits; $\mathbf{g}, \mathbf{h}$, seed (all from Blaxell 1978). Scale bar: $\mathrm{a}=1 \mathrm{~cm} ; \mathrm{f}=5 \mathrm{~mm} ; \mathrm{b}=2 \mathrm{~mm}$; $\mathrm{c}=1 \mathrm{~mm} ; \mathrm{d}, \mathrm{e}, \mathrm{g}, \mathrm{h}=0.5 \mathrm{~mm}$. 
Three geographic subspecies may be recognised within this taxon.

1 Tree; bark persistent at least on lower trunk

2 Bark persistent to small branches

3a. subsp. loxophleba

$2^{*}$ Bark smooth on larger branches and often upper trunk

3b. subsp. supralaevis

$1^{*}$ Mallee; bark wholly smooth

3c. subsp. lissophloia

3a. Eucalyptus loxophleba Benth. subsp. loxophleba

[E. amygdalina Schauer in Lehm., Pl. Preiss. 1: 130 (1844); non Labill., Nov. Holl. Pl. 2: 14 (1806). Based on Preiss 246 \& 248 from York, which were included in E. loxophleba by Bentham (1867: 254).]

Tree to $15 \mathrm{~m}$. Bark persistent to smaller branches, grey, fibrous-flaky; smaller twigs not or very slightly glaucous. Juvenile leaves petiolate, ovate to orbicular, acute to rounded, dull, bluish, to $12 \mathrm{~cm}$ long, $5 \mathrm{~cm}$ wide. Adult leaves glossy, lanceolate, falcate, acute, 6-10 cm long, 10-25 mm wide. Peduncles 2-angled, 7-12 mm long; pedicels grooved, 2-5 mm long. Mature buds obovoid, c. $6 \mathrm{~mm}$ long, c. $4 \mathrm{~mm}$ diam. Fruits conical, 4-locular, 6-8 $\mathrm{mm}$ long, 4-6 mm diam.

Distinguished by the combination: tree habit; bark persistent to smaller branches; twigs not or scarcely glaucous. Fruits are relatively small within the species.

Distribution: A species of the Wheat Belt, from around Moora to Bruce Rock, southeast to around Chillinup on the Pallinup River (Avon, Dale, Roe and Eyre Districts). Figure 3.

ECOLOGY: A common tree of the higher rainfall and higher-nutrient soils of the wetter western parts of the Wheat Belt.

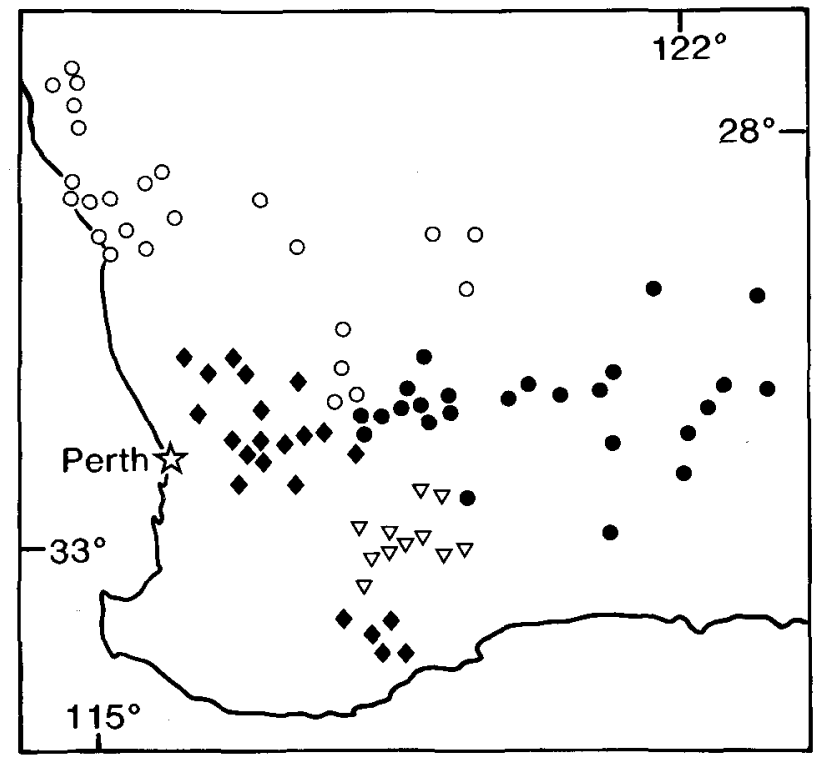

Figure 3. Distribution of E. loxophleba subsp. loxophleba ( $\bullet$ ), subsp. supralaevis $(O)$, subsp. lissophloia $(\bullet)$ and E. gratiae $(\nabla)$. 
Intergrades occur with subsp. supralaevis where the ranges join, and hybrids are recorded with E. erythronema Turcz. (sens. lat.), E. spathulata, E. vegrandis and E. wandoo Blakely.

CONSERVATION STATUS: Not considered to be at risk.

Selected specimens (from 47 examined): Western Australia: 7 miles [11 km] NW of Wongan Hills, Tindale 2795, 24 Aug 1973 (NSW, CANB, PERTH); $0.9 \mathrm{~km} \mathrm{~W}$ of Highway 95 on Gin Gin road, Hill 2963, 30 Aug 1988 (NSW); Bindoon, Johnson W 7, 9 Dec 1960 (NSW); near Northam, Morrison, Aug 1959 (NSW); near York, Diels 2914, 24 May 1901 (B, NSW); 67 km ESE of Perth on Brookton road, Blaxell W75/4, 2 Oct 1975 (NSW); Cowcowing, Koch 1094, Sep 1904 (NSW); Cunderdin, Beadle 105, 25 Oct 1972 (NSW); Meares Lake, c. 10 miles [16 km] E of County Peak, Beverley, St Barbe Moore per Sargent 706, Oct 1910 (NSW); 4 km NW of Ongerup, on Newbey's property, Hill 336, Johnson \& Blaxell, 23 Oct 1983 (NSW); $1 \mathrm{~km} \mathrm{~N}$ of Chillinup, B. Briggs 7879 \& Johnson, 11 Oct 1984 (NSW).

Intergrades between subsp. loxophleba and subsp. supralaevis: WESTERN AUSTRALIA: 10-15 km SW of Three Springs on Eneabba road, Foreman 539, 4 Sep 1984 (MEL, AD, CANB, NSW, PERTH); 28.6 miles [45.8 km] W of Watheroo, Chippendale 26, 18 Oct 1966 (CANB, NSW).

E. erythronema (sens. lat.) x E. loxophleba subsp. loxophleba: North Bungulla Nature Reserve, Brooker 9729, 23 July 1987 (CANB, NSW, PERTH).

E. loxophleba subsp. loxophleba $\times$ E. spathulata: $0.5 \mathrm{~km} \mathrm{~W}$ of Eldridge St on main road, Ongerup, Brooker 9638, 18 May 1987 (CANB, NSW, PERTH).

E. loxophleba subsp. loxophleba $\times$ E. vegrandis: $4 \mathrm{~km}$ NW of Ongerup, Hill 334, Johnson \& Blaxell, 23 Oct 1983 (NSW).

E. loxophleba subsp. loxophleba $\times$ E. wandoo subsp. pulverea: $\mathrm{S}$ of Eneabba Nat. Res., Hopper \& Brooker 10084, 20 Sep 1988 (CANB, NSW, PERTH); c. 7 miles [11 km] N of Watheroo, Johnson W 22, 9 Dec 1960 (NSW).

E. loxophleba subsp. loxophleba $\times$ E. wandoo subsp. wandoo: $5.6 \mathrm{~km}$ from Irishtown Hall on Dumbarton road, Brooker 9585, 23 Apr 1987 (CANB, NSW, PERTH); Clackline, Brooker 9586, 23 Apr 1987 (CANB, NSW, PERTH).

3b. Eucalyptus loxophleba Benth. subsp. supralaevis L. Johnson \& K. Hill, sp. nov.

Inter subspecies E. loxophlebae combinatione sequenti characteribus distinguitur: habitus arborescens; cortex ramorum laevis; ramuli plusminusve pruinosi; pedicelli graciles, mediocres vel longi; ovarium 3-4-loculare.

TYPE: WeStern Australia: $16.6 \mathrm{~km}$ W of highway on fence line $57.7 \mathrm{~km} \mathrm{~N}$ of Murchison River, K.D. Hill 2569, L.A.S. Johnson, D.F. Blaxell \& M.I.H. Brooker, 21 Nov 1986 (holo NSW; iso CANB, CBG, MEL, PERTH).

$\equiv$ E. loxophleba Benth. var. fruticosa Benth., Fl. Austral. 3: 252 (1867).

TYPE CITATION: 'Murchison river, Oldfield; Salt river, Maxwell.'

Type: Western Australia: Murchison River, A. Oldfield (lecto NSW; isolecto K, MEL; here designated). This specimen is designated the lectotype in order to fix this name to this taxon, the original syntypes representing two different subspecies (the Maxwell collection is subsp. loxophleba). This variety was included in E. foecunda var. loxophleba by Maiden (Crit. Revis. Eucalyptus 1: 112 (1904)), recognised as a variety by Blakely (1934), and included in E. loxophleba by Hall \& Johnston (1964).

Tree to $15 \mathrm{~m}$. Bark persistent to around top of trunk, grey, fibrous-flaky; branches smooth, smaller twigs glaucous. Juvenile leaves petiolate, ovate to orbicular, acute to rounded, dull, bluish, to $12 \mathrm{~cm}$ long, $5 \mathrm{~cm}$ wide. Adult leaves glossy, lanceolate, falcate, acute, 6-10 cm long, 10-25 mm wide; petioles $10-18 \mathrm{~mm}$ long; lateral veins at $10-30^{\circ}$ 
to midrib. Peduncles 2-angled, 7-12 mm long; pedicels grooved, 2-5 mm long. Mature buds obovoid, c. $6 \mathrm{~mm}$ long, c. $4 \mathrm{~mm}$ wide. Fruits conical, 3-4-locular, 6-8 mm long, 4-6 mm diam.

Distinguished by the combination of tree habit and the smooth bark from the top of the trunk. The twigs are variably glaucous, but usually distinctly so. Pedicels are slender and medium to long, and the ovary is 3-4-locular (tending to 3-locular in the north of the range).

DistRIBUTION: Widespread and common across the north of the range of the species, from the region between north of the Murchison River $\left(27^{\circ} \mathrm{S}\right)$ and around Dongara on the coast east to Lake Barlee and the Die Hardy Range, and south to Wongan Hills and Kunoppin (Irwin, Avon, Austin and Coolgardie Districts). Figure 3.

ECOLOGY: Locally abundant on deeper, loamy, often red soils on flat sites.

CONSERVATION STATUS: Widespread, not considered to be at risk.

The epithet is derived from Latin supra, above, and late Latin laevis (classically levis), smooth, in reference to the partly deciduous bark leaving the branches and sometimes the upper trunk smooth.

Selected SPECIMENS (from 40 examined): Western Australia: $34 \mathrm{~km} \mathrm{~S} \mathrm{of} \mathrm{Wannoo,} \mathrm{Blaxell} \mathrm{W75/109}$ $\mathcal{E}$ Brooker, 9 Oct 1975 (NSW, CANB); 6 miles [10 km] E of Pindar, Beard 6680, 26 Sep 1973 (PERTH, NSW); $27.6 \mathrm{~km} \mathrm{~N}$ of Burnerbinmah turnoff on Paynes Find - Yalgoo road, Hill $2582 \&$ Johnson, 24 Nov 1986 (NSW, CANB, CBG, MEL, PERTH); 4 miles [6 km] E of Geraldton, Chippendale 239, 8 Aug 1967 (CANB, NSW); near Mingenew, Diels 3037, 9 June 1901 (B, NSW); Dongara, Maiden, Oct 1909 (NSW); summit of Mt Singleton, Hill 2591 \& Johnson, 24 Nov 1986 (NSW, PERTH); Cliff Head turnoff on Brand Highway, Brooker 8633, 28 Aug 1984 (CANB, NSW, PERTH); between Beacon and Mt Churchman, Brooker 8495, 16 Mar 1984 (CANB, NSW, PERTH); $31.6 \mathrm{~km}$ $\mathrm{S}$ of Diemals-Menzies road on Bullfinch road, Hill 2613 \& Johnson, 25 Nov 1986 (NSW, PERTH); $3 \mathrm{~km}$ E of Kununoppin, Hill 2500, Johnson \& Blaxell, 16 Nov 1986 (NSW, PERTH).

3c. Eucalyptus loxophleba Benth. subsp. lissophloia L. Johnson $\mathcal{E}$ K. Hill, subsp. nov. Inter subspecies E. loxophlebae habitu pluricauli, cortice deciduo, ramulis plerumque valde pruinosis distinguitur. Ab subspecie loxophleba alabastris fructibusque majores differt.

Type: Western Australia: Cardunia Rocks, D.F. Blaxell 1749 \& L.D. Pryor, 16 Sep 1978 (holo NSW; iso CANB, K, PERTH).

Mallee to $8 \mathrm{~m}$. Bark smooth, brownish, yellow-brown or greenish to bronze, smaller twigs glaucous. Juvenile leaves petiolate, ovate to orbicular, acute to rounded, dull, bluish, to $12 \mathrm{~cm}$ long, $9 \mathrm{~cm}$ wide. Adult leaves glossy, lanceolate, falcate, acute, 8-14 $\mathrm{cm}$ long, $10-15 \mathrm{~mm}$ wide; petioles $10-18 \mathrm{~mm}$ long; lateral veins at $10-30^{\circ}$ to midrib. Peduncles 2-angled, 8-18 mm long; pedicels grooved, 2-5 mm long. Mature buds obovoid, 6-10 mm long, 3-4 mm wide. Fruits cup-shaped to conical, 4-locular, 6-9 $\mathrm{mm}$ long, 4-6 $\mathrm{mm}$ diam. Figure 4 .

Distinguished by the mallee habit, the mostly or entirely smooth bark, and the usually strongly glaucous branchlets. Buds and fruits are larger than those of subsp. loxophleba.

Subsp. 'smooth bark' of Brooker \& Kleinig (1990).

Distribution: Locally abundant through the inland southwest of Western Australia, from around Bencubbin and west of Merredin east to south of Lake Minigwal and Coonana, and south to Peak Charles (Avon, Roe, Coolgardie and southern Austin districts). Figure 3. 


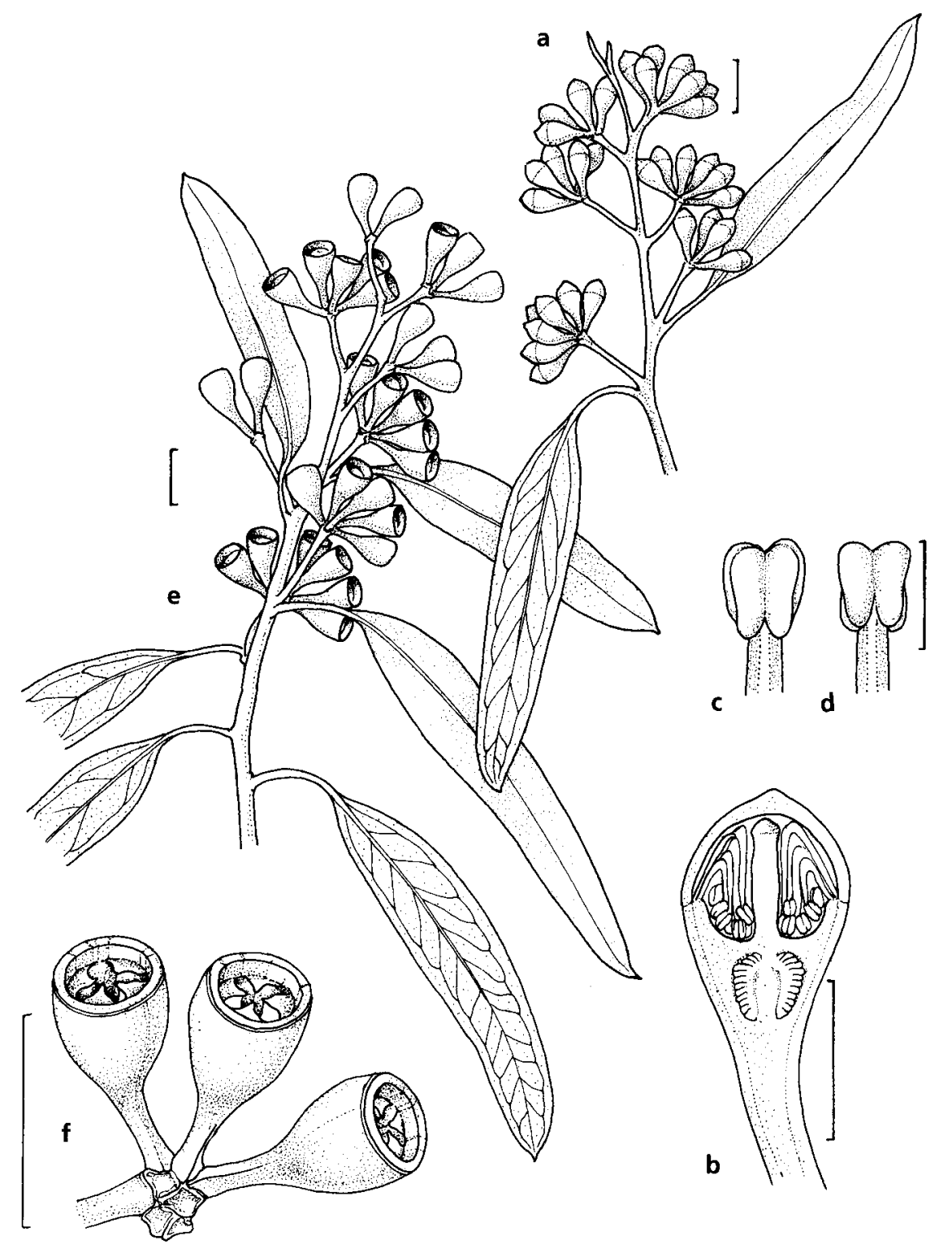

Figure 4. E. loxophleba subsp. lissophloia. a, adult leaves and buds; $\mathbf{b}$, section of bud; $\mathbf{c}$, $\mathbf{d}$, anther; e, adult leaves and fruits; $f$, fruits (all from Blaxell 1749). Scale bar: $a, e, f=1 \mathrm{~cm} ; b=5 \mathrm{~mm}$; c, $\mathrm{d}=1 \mathrm{~mm}$. 
ECOLOGY: A widely distributed taxon, occurring with a variety of mallee species on sandy soils, especially where these are shallow and overlie granitic rocks. Subspecies lissophloia does not appear to intergrade with subspecies loxophleba or with subspecies supralaevis to any great extent.

Hybrids are known with E. kruseana F. Muell. This hybrid was named E. brachyphylla C. Gardner, though it was regarded as a distinct species by its author. It was also treated as such by Chippendale (1988). Field observations show a full range of variation between the parent species, and progeny trials show segregation between the parents (Pryor \& Blaxell, pers. comm. \& in prep.). Limited intergradation also occurs between E. loxophleba subsp. lissophloia and E. gratiae (Brooker) L. Johnson \& K. Hill.

CONSERVATION STATUS: Not considered to be at risk.

The epithet is from the Greek lissos, smooth, and phloios, bark of tree, in reference to the distinctive smooth bark of this subspecies.

SELECTED SPECIMENS (from 38 examined): WeStern Australia: 3 miles [5 km] SW of Merredin, Chippendale 80,6 Mar 1967 (CANB, NSW); $6.4 \mathrm{~km} \mathrm{~N}$ of Southern Cross, Brooker 6475, 24 Aug 1979 (CANB, NSW, PERTH); $61 \mathrm{~km}$ W of Coolgardie on Southern Cross road, Brooker 5665, 6 Apr 1977 (CANB, NSW, PERTH); E side of Peak Charles, Hill 2331, Johnson \& Blaxell, 8 Nov 1986 (NSW, PERTH); $55.8 \mathrm{~km}$ E of highway in Goongarrie Reserve, Brooker 9091, 13 Nov 1985 (CANB, NSW, PERTH); $26.7 \mathrm{~km}$ E of Norseman on highway, Hill 677 A \& Blaxell, 14 Nov 1983 (NSW, CANB, PERTH); $51.7 \mathrm{~km}$ E of Karonie, Hill 567, Johnson, Blaxell, Brooker \& Hopper, 5 Nov 1983 (NSW, CANB, PERTH).

E. kruseana $\times$ E. loxophleba subsp. lissophloia: c. $40 \mathrm{~km}$ E of Widgiemooltha on road to 'Binnerinjie' homestead, Blaxell 1662, 21 June 1978 (NSW); Cardunia Rocks, Blaxell 1654 \& Pryor, 20 June 1978 (NSW).

E. gratiae x E. loxophleba subsp. lissophloia: cited under E. gratiae.

\section{Eucalyptus gratiae (Brooker) L. Johnson \& K. Hill, comb. nov.}

BASIONYM: Eucalyptus loxophleba Benth. subsp. gratiae Brooker, Nuytsia 1: 248 (1972).

Type CITATION: 'Type: 0.5 mile west of Burngup, Western Australia ( $33^{\circ} 01^{\prime} \mathrm{S}, 118^{\circ} 41^{\prime} \mathrm{E}$ ), 3 Nov. 1969, M.I.H. Brooker 2273 (holo: PERTH).'

Mallee to $8 \mathrm{~m}$. Bark smooth, brownish, yellow-brown or greenish to bronze, smaller twigs glaucous. Juvenile leaves petiolate, ovate to orbicular, acute to rounded, dull, bluish, 8-13 cm long, 5-9 cm wide. Adult leaves glossy, lanceolate, falcate, acute, 8-16 $\mathrm{cm}$ long, $15-28 \mathrm{~mm}$ wide; petioles $10-18 \mathrm{~mm}$ long; lateral veins at $10-30^{\circ}$ to midrib. Umbellasters axillary, 7-flowered, often clustered at leafless ends of small branches; peduncles 2-angled, 3-24 mm long; pedicels grooved, 2-5 mm long. Mature buds obovoid, 9-15 mm long, 4-5 mm diam.; calyptra shorter than hypanthium, hemispherical, rarely apiculate. Fruits conical, 4-5-locular, 9-12 mm long, 6-9 mm diam.; disc narrow, flat; valves deeply sunken. Seeds dull, dark brown, cuboid, to $1.5 \mathrm{~mm}$ long; chaff similar, thinner, or linear, to $4 \mathrm{~mm}$ long.

Distinguished by the mallee habit, the smooth bark, the glaucous branchlets, and the large buds and fruits. E. gratiae is in part broadly sympatric with E. loxophleba subsp. loxophleba, occupying sites with poorer or shallower soils. The two do not appear to interbreed, although limited intergradation occurs with E. loxophleba subsp. lissophloia where ranges adjoin. E. gratiae is also morphologically more distinct from the subspecies of E. loxophleba than these are from each other, and is hence raised to specific rank.

Distribution: Locally abundant in the south-eastern Wheat Belt, around the area including Pingrup, Lake Grace, Hyden and Newdegate (Roe District). Figure 3. 
ECOLOGY: Largely restricted to mallee shrublands on less fertile soils, often on lower areas or shallow soils.

CONSERVATION STATUS: Not considered to be at risk.

Selected specimens (from 14 examined): Western Australia (W to E): $5.6 \mathrm{~km} \mathrm{~N}$ of Nyabing towards Kukerin, Brooker 9142, 9 Dec 1985 (CANB, NSW, PERTH); 14 km N of Lake Grace township, Hill 327, Johnson \& Blaxell, 23 Oct 1983 (NSW, CANB, PERTH); $15 \mathrm{~km}$ E of Hyden on Lake King road, Brooker 6322, 12 Aug 1979 (CANB, NSW, PERTH); $4.1 \mathrm{~km}$ N of Giles Road on Magenta Road, Hill 3142, 7 Sep 1988 (NSW); 15.5 miles [25 km] W of Lake King township, Chippendale 224, 17 Mar 1967 (CANB, NSW).

E. gratiae x E. loxophleba subsp. lissophloia: Dragon Rock, Hill 2473, Johnson \& Blaxell, 14 Nov 1986 (NSW, PERTH).

\section{Series Astringentes}

Species 5 and 6 are placed in series Astringentes, which is defined by the combination: pith glands present; adult leaves glossy, green, with small stomata; filaments erect; anthers oblong, dorsifixed, versatile; stemonophore narrow; seeds shallowly pitted, dorsiventrally compressed. The extracodical series epithet Astringentes (referring to the included species E. astringens (Maiden) Maiden) is here substituted for 'Occidentales' as used by Pryor \& Johnson (1971), to preserve the independence of the extracodical system by avoiding confusion with Ser. Occidentales Blakely (used by Chippendale, 1988), which includes a quite different group of species of subgenus Eucalyptus ('Monocalyptus'). The extracodical epithet Occidentalosae for the subseries including E. occidentalis can remain.

\section{Eucalyptus aspratilis L. Johnson $\&$ K. Hill, nom. et stat. nov.}

$\equiv$ Eucalyptus occidentalis Endl. var. stenantha Diels ex Blakely, Key Eucalypts: 110 (1934).

TYPe CitATiOn: 'W.A. - Lake Cowan.'

Type: WeSTERn Australia: near Lake Cowan, Diels 5245, 1 Nov 1901 (holo NSW).

[E. occidentalis Endl. var. stenantha Diels ex Maiden, Crit. Revis. Eucalyptus 4: 147 (1919), nom. prov.]

$\equiv$ E. occidentalis Endl. var. grandiflora Maiden, Crit. Revis. Eucalyptus 4: 149 (1919).

TyPe CrTAtion: 'Kurrawang, W.A. (Dr. J.B. Cleland.) Type of var. grandiflora' (legend to pl. 150).

Type: Western Australia: Kurrawang, J.B. Cleland 8161/15, Sep 1915 (holo: NSW).

$\equiv$ E. eremophila (Diels) Maiden var. grandiflora Maiden, Crit. Revis. Eucalyptus 7: 22 (1923).

Mallee to $5 \mathrm{~m}$. Bark usually persistent on trunk, fibrous-scaly and shaggy; smooth above, grey and light brown. Adult leaves disjunct, lanceolate to ovate-lanceolate, acuminate, 5-12 cm long, 10-30 mm wide; petioles 9-22 mm long, slightly flattened; lateral veins indistinct, well-spaced, at $20-60^{\circ}$ to midrib, irregularly branched; intramarginal vein indistinct. Umbellasters axillary, 7-flowered; peduncles 2-angled or somewhat flattened apically, $1.6-2.3 \mathrm{~cm}$ long, to $4 \mathrm{~mm}$ wide, often reflexed; pedicels angled, 6-11 mm long. Mature buds 25-33 mm long, 5-6 mm diam.; calyptra cylindrical, obtuse, slightly flared at base, narrower than hypanthium, 2-3 times longer than hypanthium. Fruits elongate, cup-shaped or pyriform, 4- or 5-locular; hypanthium 


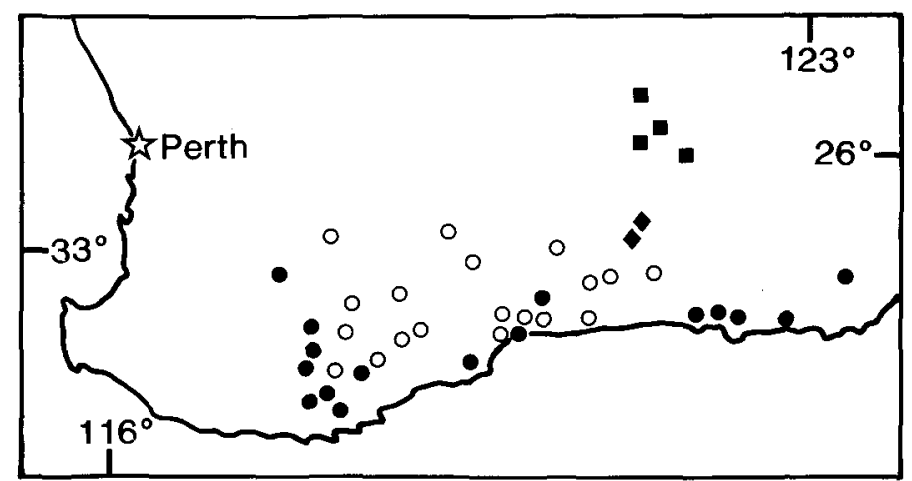

Figure 5. Distribution of E. occidentalis $(\bullet)$, E. species $\mathrm{F}(O)$, E. aspratilis $(\boldsymbol{\square})$ and E. aspratilis $E$. species $\mathrm{F}$ intergrades $(\bullet)$.

11-14 mm long, 8-10 mm wide; calyptra scar c. $1 \mathrm{~mm}$ wide, appearing continuous with disc; disc broad, initially slightly raised, ultimately strongly incurved for more than half its width, and enclosing valve bases; valves narrowly triangular, vertically exserted, strongly acuminate. Seeds dark brown, satiny, angular, cuboid, to $2 \mathrm{~mm}$ long; chaff dull, brown, either cuboid, to $1 \mathrm{~mm}$ long, or linear, to $4 \mathrm{~mm}$ long.

Distinguished within the series Occidentales by the mallee habit and the persistent bark on the trunk. Anthers are relatively large in comparison with those of related species.

DistRIBUTION: An uncommon species in the region south from around Coolgardie to east of Norseman (Coolgardie District). Figure 5. A disjunct population around Peak Charles is intermediate between this taxon and E. species F of Brooker \& Kleinig (1990).

ECOLOGY: Restricted to mallee heath communities on shallow sandy soils around granite domes.

CONSERVATION STATUS: 3R-. Although widely scattered, E. aspratilis is restricted to a very narrow habitat range.

The epithet is from the Latin aspratilis, rough, referring to the persistent bark, in contrast to that of the related $E$. species $F$.

Selected SPECimens (from 7 examined): Western Australia (N to S): Twenty-five Mile Rocks, Brooker 8902, 7 Apr 1985 (CANB, NSW, PERTH); Burra Rock, Hill 2636 \& Johnson, 26 Nov 1986 (NSW, PERTH); $52.5 \mathrm{~km} \mathrm{~W}$ of Coolgardie-Norseman road on Hyden track, Hill 2854, 25 Aug 1988 (NSW).

E. aspratilis - E. species F intergrade: E side of Peak Charles, Hill 2333, Johnson \& Blaxell, 8 Nov 1986 (NSW, PERTH).

6. Eucalyptus sargentii Maiden, Crit. Revis. Eucalyptus 7: 58 (1924).

Type Citation: 'Type - Meare's Lake, County Peak, Beverley, Western Australia, O.H. Sargent. No. 707.'

TYPE: holo NSW; iso CANB.

Tree to $12 \mathrm{~m}$ or mallee. Bark usually persistent on lower of trunk, dark grey to black, 
coarsely platy-fibrous, smooth above, semiglossy grey, olive, red-brown or bronze. Juveniles leaves subsessile, opposite and lanceolate for 3-4 nodes, then becoming disjunct, linear, to $7 \mathrm{~cm}$ long, $3 \mathrm{~mm}$ wide. Adult leaves narrow-lanceolate, 5-10 cm long, 5-13 mm wide; petioles $8-14 \mathrm{~mm}$ long; lateral veins moderately spaced, at $20-40^{\circ}$ to midrib; oil glands densely packed, spherical. Inflorescences simple, axillary; umbellasters 7-flowered; peduncles 6-22 mm long; pedicels 3-8 $\mathrm{mm}$ long. Buds cylindrical, 16-30 mm long, 4-7 mm diam.; calyptra 3 or more times longer than hypanthium, elongate-conical, acuminate. Stamens all fertile; filaments erect in bud; anthers oblong, dorsifixed, versatile, dehiscing through parallel slits. Fruits cylindrical, usually wider at apex, to obconical, 7-12 $\mathrm{mm}$ long, 5-9 mm diam.; stemonophore persistent, flat; disc flat, depressed towards centre; valves erect, acicular, basally enclosed, apically exserted. Seeds brown to red-brown, satiny, ovoid, shallowly regularly reticulate; chaff dull.

Two geographic subspecies are recognised.

1 Buds less than $24 \mathrm{~mm}$ long; fruits $8 \mathrm{~mm}$ or less diam.

6a. subsp. sargentii

$1^{*}$ Buds more than $24 \mathrm{~mm}$ long; fruits $8 \mathrm{~mm}$ or more diam.

6b. subsp. fallens

\section{6a. Eucalyptus sargentii Maiden subsp. sargentii}

Tree to $12 \mathrm{~m}$, rarely a mallee. Bark persistent on lower trunk. Adult leaves narrowlanceolate, $6-10 \mathrm{~cm}$ long, 5-13 mm wide; petioles 8-12 mm long. Peduncles 6-22 $\mathrm{mm}$ long; pedicels $3-5 \mathrm{~mm}$ long. Buds cylindrical, $16-23 \mathrm{~mm}$ long, $4-5 \mathrm{~mm}$ diam. Fruits cylindrical to obconical, $7-10 \mathrm{~mm}$ long, 5-8 $\mathrm{mm}$ diam.

Distribution: From Coorow to Lake Meares, east to Lake Hurlstone (Avon and Roe Districts). Figure 6.

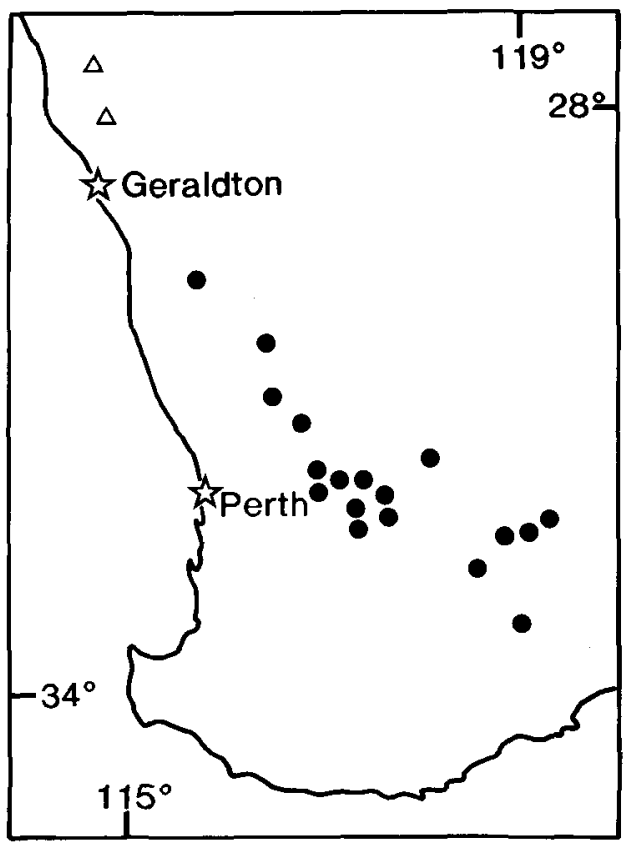

Figure 6. Distribution of $E$. sargentii subsp. sargentii $(\bullet$ and subsp. fallens $(\triangle)$. 
ECOLOGY: Sporadically distributed but locally abundant in highly saline situations bordering salt lakes and swamps.

Conservation status: Not considered to be at risk.

SELECTED SPECIMENS (from 27 examined): WFSTERn AustRALIA (W to E): Woollberoo, ESE of Coorow, Brooker 9058, 3 Nov 1985 (CANB, NSW, PERTH); $11.8 \mathrm{~km}$ E of rail crossing at Carani, Brooker 7582, 26 Aug 1982 (CANB, NSW, PERTH); $1.0 \mathrm{~km} \mathrm{~W}$ of Kauring rail crossing on York road, Hill 2965m 30 Aug 1988 (NSW); 8 miles [c. $12 \mathrm{~km}$ ] SSE of Dangin, Johnson W117, 14 Dec 1960 (NSW); saltflats near Quairading, Blaxell W75/80 \& Brooker, 4 Oct 1975 (NSW, CANB, K, PERTH); $7.9 \mathrm{~km} \mathrm{~W}$ of Pingaring, Brooker 9478, 21 Oct 1986 (CANB, NSW, PERTH); $12.1 \mathrm{~km} \mathrm{~N}$ of Ryans Road on Lockhart Road, Hill 3140, 7 Sep 1988 (NSW); 2.3 km E of Ravensthorpe road on Holland track, Hill 2475, Johnson \& Blaxell, 14 Nov 1986 (NSW, CANB, CBG, MEL, PERTH).

6b. Eucalyptus sargentii Maiden subsp. fallens $L$. Johnson $\mathcal{E} K$. Hill, subsp. nov.

$\mathrm{Ab}$ subspecie sargentii alabastris fructibusque majoribus distinguitur.

Type: Western Australia: $3 \mathrm{~km} \mathrm{~N}$ of Binnu on Highway 1, K.D. Hill 2565, L.A.S. Johnson, D.F. Blaxell \& M.I.H. Brooker, 21 Nov 1986 (holo NSW; iso PERTH).

Tree to $6 \mathrm{~m}$ or mallee. Bark persistent on base of trunk in larger individuals only. Adult leaves narrow-lanceolate, 5-8 cm long, 6-12 mm wide; petioles 9-14 mm long. Peduncles 12-16 mm long; pedicels 4-8 mm long. Buds cylindrical, 25-30 mm long, 6-7 mm diam. Fruits cylindrical to obconical, $10-12 \mathrm{~mm}$ long, 8-9 $\mathrm{mm}$ diam. Figure 7.

Distinguished from subsp. sargentii by the larger buds and fruits (buds $16-23 \mathrm{~mm}$ long, 4-5 mm diam., fruits 7-10 $\mathrm{mm}$ long, 5-8 $\mathrm{mm}$ diam. in E. sargentii). Anthers in the Binnu population are larger than those of subsp. sargentii.

Distribution: Known from two populations, near Binnu, and about $60 \mathrm{~km}$ north of there on Eurardy Station (Irwin District). Figure 6.

ECOLOGY: Restricted to somewhat saline soils around salty swamps or creek lines.

No intergrades occur with the more southerly E. sargentii, which, though somewhat variable in size of its parts, does not exhibit any widespread clinal approach to subsp. fallens.

CONSERVATION STATUS: 2R-.

The epithet is from the Latin fallens, in its sense of 'deceiving', since on its earlier observations it was mistaken for a species of the E. eremophila group.

Selected SPECIMENS (from 5 examined): Western Australia: Bungabandi Creek, Brooker 9471, 9 Oct 1986 (CANB, NSW, PERTH); 3 km N of Binnu, Brooker 9063, 4 Nov 1985 (CANB, NSW, PERTH).

\section{Series Erythronemae}

Together with others to be described elsewhere, species 7 to 14 are placed in series Erythronemae subseries Platypodosae, defined by the combination: pith glands present; stomata large, translucent; filaments erect well before maturity of the bud; anthers oblong, dorsifixed, versatile; stemonophore broad; seeds distinctly reticulately pitted, dorsiventrally compressed.

7. Eucalyptus spathulata Hook., Hooker's Icon. Pl. 7: t. 611 (1844).

Type citation: 'Hab. Swan River. Jas. Drummond, (Suppl. Coll. n. 20).'

Trpe: Western Australia: Swan River Colony, J. Drummond, supplementary collection, no. 20 (holo K). 


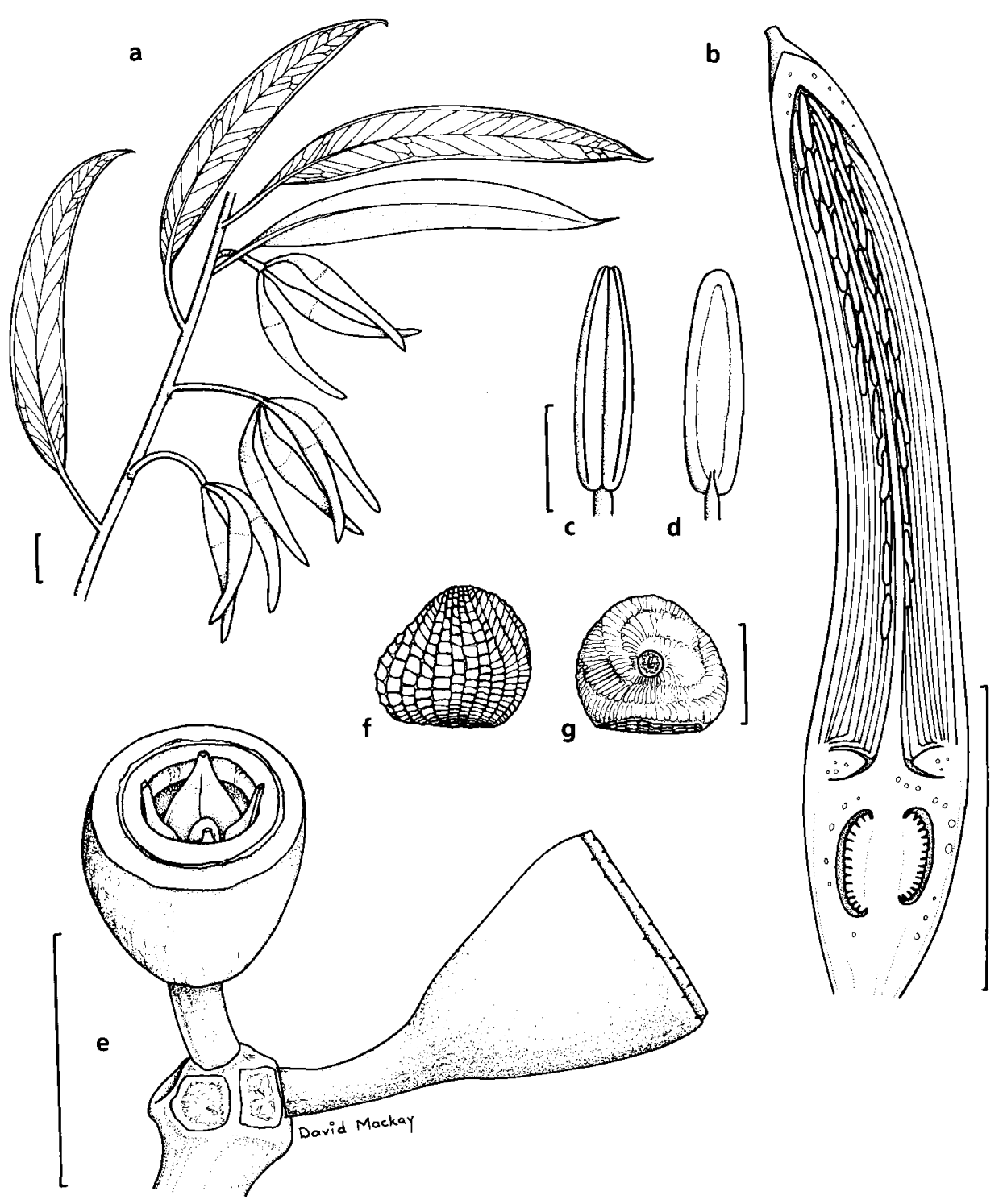

Figure 7. E. sargentii subsp. fallens. a, adult leaves and buds; $\mathbf{b}$, section of bud; $\mathbf{c}, \mathbf{d}$, anther; $\mathbf{e}$, fruits; f, $\mathbf{g}$, seed (all from Brooker 9036). Scale bar: $\mathbf{a}, \mathbf{b}, \mathrm{e}=1 \mathrm{~cm} ; \mathrm{c}, \mathrm{d}, \mathrm{f}, \mathrm{g}=1 \mathrm{~mm}$. 
Tree (mallet) to $12 \mathrm{~m}$. Bark smooth, semiglossy, dark grey to red-brown or bronze. Juvenile leaves disjunct, linear. Adult leaves disjunct, linear, glossy, with a distinct bluish sheen from the large translucent stomata, 5-9 $\mathrm{cm}$ long, 2-4 $\mathrm{mm}$ wide; lateral veins scattered; reticulation sparse, incomplete; oil glands crowded, spherical. Inflorescences simple, axillary; umbellasters 7-flowered; peduncles flattened, 5-15 mm long; pedicels flattened or angular, 2-4 mm long. Buds cylindrical, $10-13 \mathrm{~mm}$ long, 3-4 mm diam.; calyptra more than 2 times longer than hypanthium, cylindrical, apically rounded to acute. Stamens all fertile; filaments erect; anthers oblong, dorsifixed, dehiscing through parallel slits. Fruits ovoid to obconical or hemispherical, 4-6 mm long, 4-6 mm diam.; stemonophore broad, flat, persistent; disc flat; valves acicular, basally enclosed, apically exserted. Figure 8 .

The above description applies to a narrowed circumscription of E. spathulata, and is included here to allow comparison with segregate taxa described below.

The non-lignotuberous 'mallet' habit, where main branches arise acutely at more or less the same point on the trunk, occurs apparently independently in several groups of otherwise mallee species in Western Australia. E. spathulata in the restricted sense is an example, being a 'mallet' whereas the segregate taxa (below) are mallees. It is also more restricted in range and more specialised in habitat.

Distribution: Locally frequent, in the Tammin-Pingaring-Dumbleyung-Ongerup region (Avon and Roe Districts). Figure 9.

ECOLOGY: Localised in mallet woodlands, on saline sites around salt pans or along drainage lines.

Intergrades occur with $E$. vegrandis, and hybrids are known with $E$. loxophleba subsp. loxophleba and E. platypus Hook. (a specimen of the latter hybrid constitutes the type of E. platypus Hook. var. heterophylla Blakely).

CONSERVATION STATUS: $3 \mathrm{~V}$. Although locally frequent, this species occurs almost entirely in agricultural country. The habitat is also very narrow, fringing saline areas. Agricultural practices are causing rapid spread of these saline areas, in many sites engulfing the habitat of this species faster than the species can propagate into the newly created fringing zones.

SeleCteD SPECIMENS (from 15 examined): Western Australia: $4.5 \mathrm{~km} \mathrm{~W}$ of Tammin, L. Johnson 9112 $\mathcal{E}$ M. Johnson, 18 May 1988 (NSW, PERTH); $21.8 \mathrm{~km}$ S of Lake Grace, Hill 328, Johnson \& Blaxell, 23 Oct 1983 (NSW); $24 \mathrm{~km}$ from Katanning on road to Nyabing, Crisp 5195, 16 Jan 1975 (CBG,

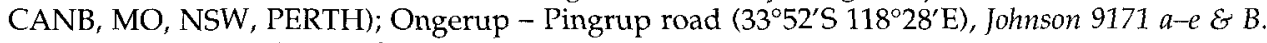
Briggs, 31 Oct 1988 (NSW, CANB).

E. loxophleba subsp. loxophleba $\times$ E. spathulata: cited under the former.

E. platypus x E. spathulata: $10 \mathrm{~km}$ NNW of Ongerup, Hopper 2401, 31 July 1982 (PERTH, photo NSW); near Ongerup, Stoward 133, 30 May 1917 (NSW, type of E. platypus var. heterophylla).

E. spathulata - E. vegrandis intergrades: Harrismith, Gardner 2105, 5 May 1924 (PERTH, NSW); 6 miles [10 km] N of Lake Grace, Johnson W 235, 19 Dec 1960 (NSW); $19 \mathrm{~km} \mathrm{~N}$ of Ongerup on Lake Grace road, B.Briggs 7926 \& Johnson, 11 Oct 1984 (NSW, PERTH).

\section{Eucalyptus vegrandis L. Johnson $\mathcal{E}$ K. Hill, sp. nov.}

Affinis E. spathulatae sed habitu pluricauli, foliis latioribus et fructibus majoribus distinguitur.

TYPE: Western Australia: $5 \mathrm{~km}$ NW of Ongerup, K.D. Hill 337, L.A.S. Johnson E D.F. Blaxell, 23 Oct 1983 (holo NSW; iso CANB, PERTH) 

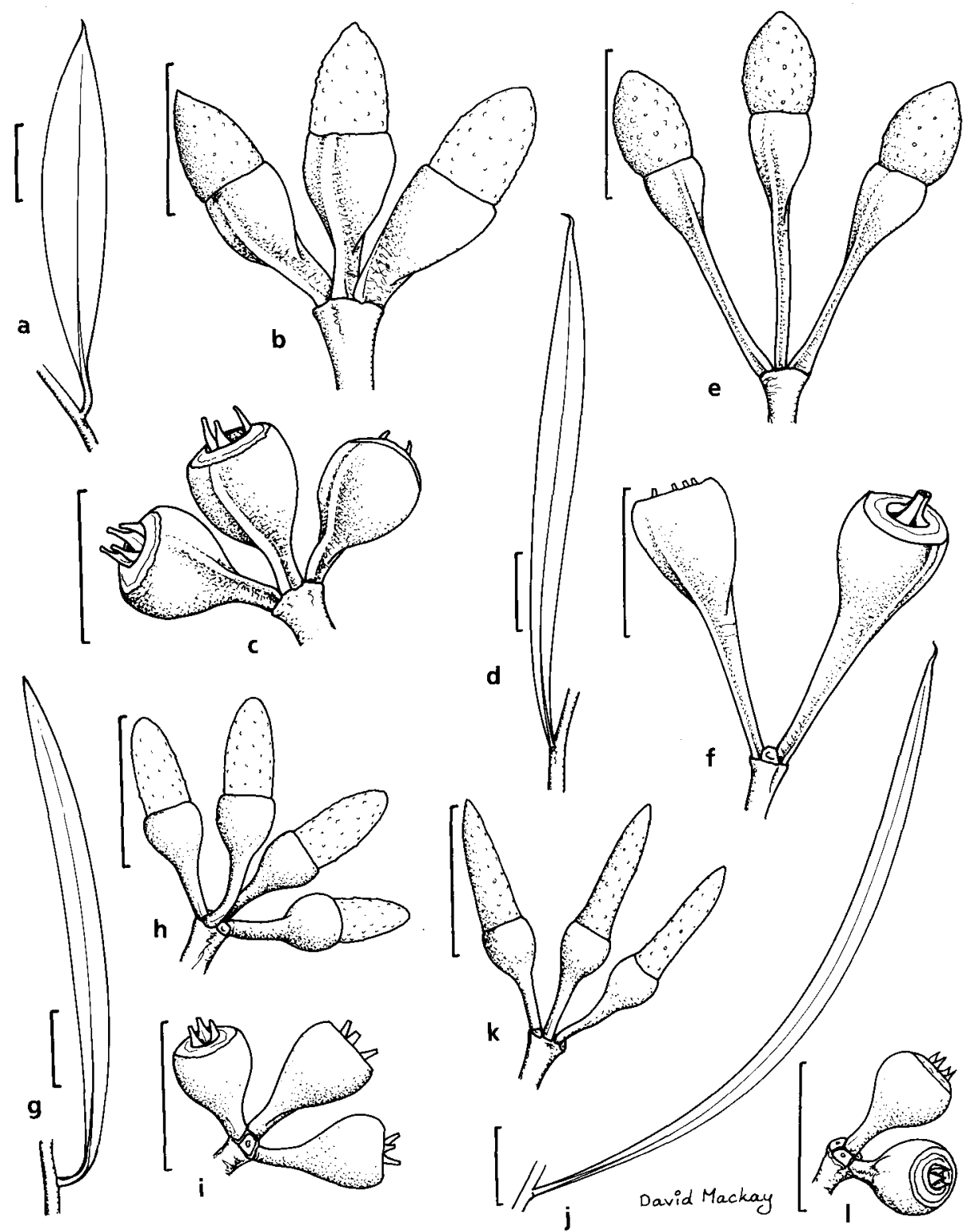

Figure 8. E. suggrandis subsp. suggrandis. a, adult leaf; b, buds; c, fruits (a, c from Blaxell 1697, b from Brooker 8659). E. suggrandis subsp. alipes. d, adult leaf; e, buds; $\mathbf{f}$, fruits (all from Blaxell W75/26 \& Brooker). E. vegrandis. g, adult leaf; h, buds; i, fruits (all from Fitzgerald, Nov 1907). E. spathulata. $\mathbf{j}$, adult leaf; $\mathbf{k}$, buds; $\mathbf{1}$, fruits (all from Hill 328, Johnson \& Blaxell). Scale bar $=1 \mathrm{~cm}$. 


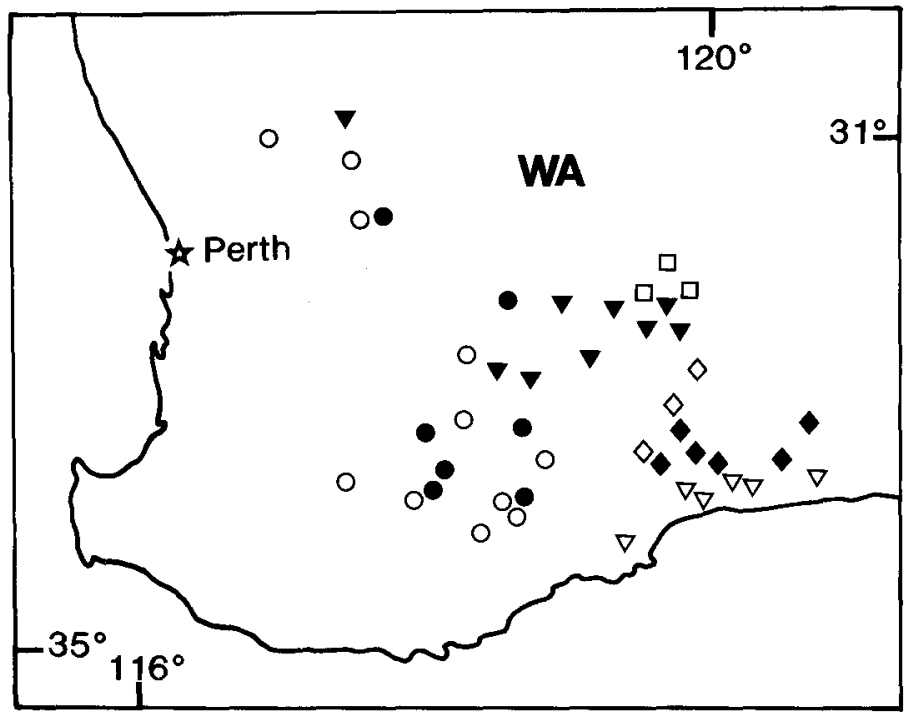

Figure 9. Distribution of E. spathulata $(\bullet)$, E. vegrandis $(O)$, E. suggrandis subsp. suggrandis $(\nabla)$, subsp. alipes $(\boldsymbol{\nabla})$, subsp. alipes - subsp. suggrandis intergrades ( $\bullet)$, E. steedmanii $(\square)$ and E. goniocarpa $(\diamond)$.

Mallee to $6 \mathrm{~m}$, often less. Bark smooth, semiglossy, grey to brown or bronze. Juvenile leaves disjunct, linear to narrow-lanceolate. Adult leaves disjunct, linear to lanceolate, glossy, with a distinct bluish sheen from the large translucent stomata, $3-8 \mathrm{~cm}$ long, 3-8 $\mathrm{mm}$ wide; lateral veins scattered; reticulation sparse, incomplete; oil glands crowded, spherical. Inflorescences simple, axillary; umbellasters 3- or 7-flowered; peduncles 5-15 mm long; pedicels 2-4 mm long. Buds cylindrical, 8-12 mm long, 3-5 mm diam.; calyptra slightly Ionger to almost 2 times longer than hypanthium, cylindrical, apically rounded. Stamens all fertile; filaments erect; anthers oblong, dorsifixed, dehiscing through parallel slits. Fruits ovoid to obconical or hemispherical, 5-8 mm long, 5-8 $\mathrm{mm}$ diam.; stemonophore broad, flat, persistent; disc flat; valves acicular, basally enclosed, apically exserted. Figure 8 .

Differs from E. spathulata in the mallee habit, shorter and broader leaves, shorter calyptra and larger fruits. This taxon has a considerably wider range than $E$. spathulata, although the two are sympatric in the south of the range of $E$. vegrandis. Where the two are sympatric, $E$. spathulata occurs on low saline sites while $E$. vegrandis occurs on higher, sandy sites.

There is some breakdown between the two taxa in areas where both occur. Both species and some intergrades in the contact zones can be observed on the Pingrup road $\mathrm{N}$ of Ongerup, as was pointed out to us in the field by the late Ken Newbey. Occasional hybrids with E. xanthonema Turcz., i.e. E. xanthonema subsp. xanthonema as recognised by Brooker \& Hopper (1991), are also recorded.

In the northernmost part of its area (north of c. $31^{\circ} 15^{\prime} S$ ), E. vegrandis has 3-flowered umbellasters (mostly 7-flowered in the south) and the fruits are larger than is general in the south. 
Distribution: Scattered and sporadic, from Wongan Hills south to Arthur River and southeast to Ongerup (Avon and Roe Districts). Figure 9.

ECOLOGY: Usually on moderately well-drained sandy loams, but often not far from somewhat saline areas.

Conservation status: Not considered to be at risk.

The epithet is from the Latin vegrandis, not very large, referring both to its small stature and because it has been confused with $E$. suggrandis under the name E. spathulata var. grandiflora.

Selected specimens (from 14 examined): Western Australia (W to E): c. $12 \mathrm{~km}$ E of rail crossing at Carani, Brooker 7584, 26 Aug 1982 (CANB, NSW, PERTH); $0.9 \mathrm{~km}$ from Dowerin-Trayning road on Minnievale Road, Brooker 9748, 3 Sep 1987 (CANB, NSW, PERTH); Cunderdin,Fitzgerald, Nov 1907 (NSW); Carganocking Hill, Hill 654, Johnson, Blaxell, Brooker \& Hopper, 8 Nov 1983 (NSW, CANB, PERTH); Broome Hill, Morrison, 16 Apr 1904 (NSW); 6 km N of Borden, Crisp 5174, 15 Jan 1979 (CBG, CANB, NSW, PERTH).

E. spathulata $-E$. vegrandis intergrades: cited under the former.

E. loxophleba subsp. loxophleba $\times$ E. vegrandis: specimens cited under the former.

E. vegrandis x E. xanthonema: 24 miles [ $38 \mathrm{~km}$ ] S of Williams, Melville 4358 \& Royce, 28 Aug 1953 (K, NSW)

\section{Eucalyptus suggrandis L. Johnson $\mathcal{E}$ K. Hill, sp. nov.}

Ab E. spathulata habitu multicauli plusminusve fruticoso, ab illa et ab E. vegrandi et E. spathulata alabastris fructibusque majoribus distinguitur.

Type: Western Australia: Hamersley Drive, $32.5 \mathrm{~km}$ from Old Ongerup Road, Fitzgerald River National Park, K.D. Hill 3147, 7 Sep 1988 (holo NSW; iso CANB).

$\equiv$ Eucalyptus spathulata Hook. var. grandiflora Benth., Fl. Austral. 3: 236 (1867).

Type citation: 'Phillips Range, Maxwell.'

Type: Western Australia: Phillips Range, Maxwell (holo K; iso NSW).

EE. spathulata Hook. subsp. grandiflora (Benth.) L. Johnson \& Blaxell, Contrib. New South Wales Natl Herb. 4(7): 453 (1973).

Although this taxon includes a previously published variety (and subspecies), we have chosen to publish it as a new species with a new type from a known locality. This is preferred because the old concept of E. spathulata is now divided into four taxa, and where possible we have nominated types from known and studied populations.

Mallee to $4 \mathrm{~m}$. Bark smooth, semiglossy, grey to light brown or bronze. Juvenile leaves disjunct, narrow-lanceolate. Adult leaves disjunct, narrow-lanceolate to lanceolate, glossy, with a distinct bluish sheen from the large, translucent stomata, $4-8 \mathrm{~cm}$ long, 5-15 mm wide; lateral veins scattered; reticulation sparse, incomplete; oil glands crowded, spherical. Inflorescences simple, axillary; umbellasters 3-7-flowered; peduncles flattened, 8-15 mm long; pedicels flattened, 3-8 $\mathrm{mm}$ long. Buds often 2-winged, ovoid to shortly fusiform, 11-17 mm long, 5-7 mm diam.; calyptra slightly longer to 1.5 times longer than hypanthium, shortly cylindrical or convex-conical, apically rounded, smooth or finely verrucose. Stamens all fertile; filaments erect; anthers oblong, dorsifixed, dehiscing through parallel slits. Fruits ovoid to obconical, 8-12 mm long, 6-9 mm diam.; stemonophore broad, flat, persistent; disc flat; valves acicular, basally enclosed, apically exserted. Figure 8.

This taxon differs from E. spathulata and E. vegrandis in the larger buds with shorter calyptra, the larger fruits, and the broader leaves. 
The epithet is from the Latin suggrandis, rather large, referring to the size of buds and fruits in comparison with E. spathulata and E. vegrandis.

Two subspecies, showing considerable intergradation where their ranges meet, are recognised on the basis of regional variation in leaf shape, bud number and ornamentation, and pedicel length.

1 Pedicel less than $4 \mathrm{~mm}$ long, umbellasters 3-7-flowered .... 9a. subsp. suggrandis

$1^{*}$ Pedicel more than $4 \mathrm{~mm}$ long, umbellasters consistently 3-flowered 9b. subsp. alipes

\section{9a. Eucalyptus suggrandis L. Johnson $\mathcal{E} K$. Hill subsp. suggrandis}

Mallee. Adult leaves lanceolate to broad-lanceolate. Umbellasters 3-7-flowered. Peduncle 8-12 mm long, not strongly flattened. Pedicels 3-5 $\mathrm{mm}$ long, ribbed but not strongly winged. Buds 11-15 $\mathrm{mm}$ long, 5-6 $\mathrm{mm}$ diam, calyptra smooth or finely verrucose. Fruits 8-11 mm long, 8-9 mm diam. Figure 8.

Distinguished by the short pedicels and often 7-flowered umbellasters. In mature buds the calyptra is generally more warty than in subsp. alipes. The characters of the subspecies are most marked in the southernmost parts of the range.

Distribution: Locally frequent, from the Gairdner River to the Young River, south of about $33^{\circ} 35^{\prime} \mathrm{S}$ (Eyre District). Figure 9.

ECOLOGY: A component of mixed mallee heath on various low-nutrient substrates.

Hybrids are recorded with E. platypus Hook. and E. species F (Brooker \& Kleinig 1988).

CONSERVATION STATUS: Not considered to be at risk.

Selected specimens (from 19 examined): Western Australia (W to E): c. $10 \mathrm{~km} \mathrm{~S}$ of Ravensthorpe on Hopetoun road, Blaxell 1697, 23 June 1978 (NSW); Eldverton via Ravensthorpe, Brooker 8659, 4 Sep 1984 (CANB, NSW, PERTH); E slope of Mt Desmond, B. Briggs 7716 \& Johnson, 10 Oct 1984 (NSW, PERTH); $4.5 \mathrm{~km}$ S of highway on Mason Bay road, Hill 2359, Johnson, Blaxell \& Brooker, 9 Nov 1986 (NSW); $14.1 \mathrm{~km}$ S of Old Ongerup Road on Hamersley Drive, Fitzgerald River Natl Park, B. Briggs 7685, 7686, 7687 E Johnson, 9 Oct 1984 (NSW, PERTH); $10.0 \mathrm{~km}$ NW of Fitzgerald River Natl Park entrance on Devils Creek Road, Hill 3111, 3112, 6 Sep 1988 (NSW, CANB, PERTH); NW of Mt Maxwell, Brooker 9910, 9911, 9 Mar 1988 (CANB, NSW).

Intergrades between the subspecies ( 8 examined): $44 \mathrm{~km} \mathrm{~N}$ of Ravensthorpe - Albany road on Lake King road, Hill 2381, Johnson, Blaxell \& Brooker, 9 Nov 1986 (NSW, PERTH); $11.7 \mathrm{~km}$ from Ravensthorpe-Lake King road on Aerodrome Road, Hill 3023, 1 Sep 1988 (NSW); 13.5 km from highway on Fitzgerald Road ( $\left.33^{\circ} 25^{\prime} \mathrm{S} 119^{\circ} 45^{\prime} \mathrm{E}\right)$, Brooker 8808, 18 Jan 1985 (CANB, NSW, PERTH); $55 \mathrm{~km}$ W of Fields Road (5 ways) on Ravensthorpe track, Hill 2343, Johnson \& Blaxell, 8 Nov 1986 (NSW, PERTH); Ravensthorpe, Ralph \& Stamford, 26 June 1924 (NSW).

E. suggrandis subsp. suggrandis $\times$ E. species F: $15.6 \mathrm{~km}$ from Highway 1 along Brook Road

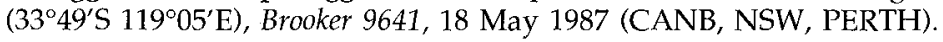

9b. Eucalyptus suggrandis L. Johnson $\mathcal{E}$ K. Hill subsp. alipes L. Johnson $\mathcal{E}$ K. Hill, subsp. nov.

Ab subspecie typica pedicellis longis aliquanto alatis et umbellastris semper trifloris differt.

TYPE: WesteRn AustRAlia: $46.0 \mathrm{~km} \mathrm{~N}$ of Coolgardie - Hyden road on Southern Cross road, K.D. Hill 2894, 26 Aug 1988 (holo NSW; iso CANB, PERTH).

Mallee. Adult leaves narrow-lanceolate to lanceolate. Umbellasters 3-flowered. Peduncle strongly flattened, 10-15 mm long. Pedicels 2-winged, 4-8 mm long. Hypanthium 2-winged; 
calyptra smooth. Fritts $8-12 \mathrm{~mm}$ long, 6-8 $\mathrm{mm}$ diam. Figure 8 .

Distinguished by the long, winged pedicels and always 3-flowered umbellasters. The related taxa E. goniocarpa and E. steedmanii are also 3-flowered, but have substantially larger buds and fruits (see below).

Distribution: This subspecies ranges from Lake Grace to east of Hyden and midway between Lake King and Ravensthorpe (Roe and Eyre Districts). Figure 9.

Ecology: A frequent component of mallee heath on sandy loam or sandplain, usually in low mixed mallee communities.

Hybrids are recorded with $E$. depauperata.

CONSERvation STATUS: Not considered to be at risk.

The epithet is from the Latin ala, a wing, and pes, a foot, referring to the pedicels. It does not change with gender of the generic name and is pronounced as three syllables with the stress on the first.

Selected specimens (from 11 examined): Western Australia (W to E): 0.95 miles [1.5 km] E of Manmanning, Smith 1158, 11 Mar 1989 (MEL, AD, BRI, CANB, NSW, PERTH); $31.8 \mathrm{~km}$ W of Hyden towards Kondinin, Hill 643, Johnson, Blaxell, Brooker \& Hopper, 8 Nov 1983 (NSW, CANB, PERTH); $4.2 \mathrm{~km} \mathrm{~S}$ of Varley road on Dragon Rock road, Hill 2470, Johnson \& Blaxell, 14 Nov 1986 (NSW, PERTH); $43 \mathrm{~km}$ E of Hyden, Blaxell W75/26 E Brooker, 3 Oct 1975 (NSW); $46.0 \mathrm{~km} \mathrm{~N}$ of Coolgardie-Hyden road on Southern Cross road, Hill 2894, 26 Aug 1988 (NSW, CANB, PERTH); 13 miles [22 km] NE of Lake Grace, M.I.H. Brooker 2271, 5 June 1969 (CANB, NSW, PERTH).

E. suggrandis subsp. alipes - subsp. suggrandis intergrades $x$ E. vegrandis: Facup Creek, Diels 4767,8 Oct 1901 (B, NSW).

E. depauperata $\times$ E. suggrandis subsp. alipes: cited under E. depauperata.

E. platypus x E. suggrandis subsp. alipes: $10 \mathrm{~km}$ from Lake King towards Newdegate, Strid 21964, 1 Jan 1983 (NSW).

\section{Eucalyptus goniocarpa L. Johnson $\mathcal{E} K$. Hill, sp. nov.}

$\mathrm{Ab}$ E. eremophila umbellastris saepissime trifloris et alabastris fructibusque bialatis differt. $\mathrm{Ab}$ E. suggrandi subsp. alipede foliis alabastris et fructibus plerumque majoribus differt.

TYPe: Western Australia: $5.6 \mathrm{~km}$ from Lake King on Ravensthorpe road, K.D. Hill 2383, L.A.S. Johnson, D.F. Blaxell E M.I.H. Brooker, 9 Nov 1986 (holo NSW; iso PERTH).

Tree (mallet) to $5 \mathrm{~m}$, sometimes mallee to $4 \mathrm{~m}$. Bark smooth, semiglossy, grey to brown or bronze. Juvenile leaves disjunct, lanceolate. Adult leaves disjunct, lanceolate, glossy, with a distinct bluish sheen from the large, translucent stomata, 4-8 cm long, 5-10 $\mathrm{mm}$ wide; lateral veins scattered; reticulation sparse, incomplete; oil glands crowded, spherical. Inflorescences simple, axillary; umbellasters 3(-7)-flowered; peduncles flattened, 8-15 mm long; pedicels flattened, 3-8 mm long. Buds distinctly 2-winged, ovoid to shortly fusiform, 11-17 mm long, 5-7 mm diam.; calyptra slightly longer to 2 times as long as hypanthium, shortly cylindrical or convex-conical, apically rounded. Stamens all fertile; filaments erect; anthers oblong, dorsifixed, dehiscing through parallel slits. Fruits 2-winged, ovoid to obconical, 8-12 $\mathrm{mm}$ long, 6-9 mm diam.; stemonophore broad, flat, persistent; disc flat; valves acicular, basally enclosed, apically exserted. Seeds ovoid, somewhat flattened, grey-brown, regularly shallowly reticulate. Figure 10.

Distinguished from E. eremophila by the mostly 3-flowered umbellasters and the 2-winged buds and fruits. This taxon shows some resemblances to $E$. suggrandis subsp. alipes, from which it differs in the larger leaves, buds and fruits. E. steedmanii is also 3-flowered, but has strikingly quadrangular buds and fruits. 

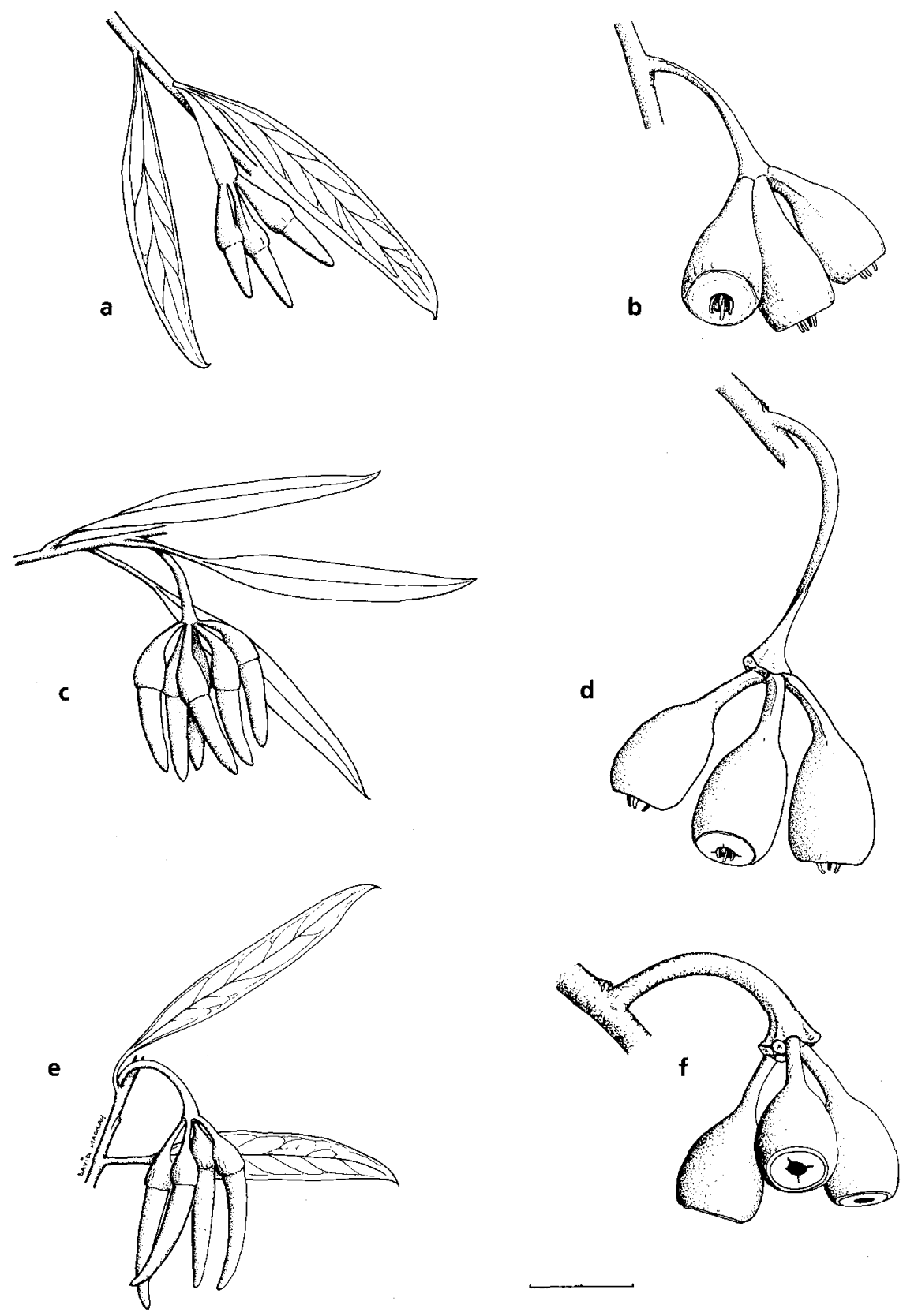

Figure 10. E. goniocarpa. a, adult leaves and buds; b, fruits (all from Hill 2383, Johnson, Blaxell \& Brooker). E. eremophila. c, adult leaves and buds; d, fruits (all from Hill 219 \& Johnson). E. tenera. e, adult leaves and buds; f, fruits (all from Hill $2480 \&$ Johnson). Scale bar $=1 \mathrm{~cm}$. 
This taxon has been referred to E. eremophila subsp. pterocarpa (Blakely \& Steedman) L. Johnson \& Blaxell (Brooker \& Kleinig 1990: 146). The latter is, however, said to occur in rocky sites, with no mention of the 'mallet' habit. This represents another possibly distinct species related to E. eremophila, and has not been rediscovered to date. It is distinguished by the larger fruits on longer pedicels, and the entire adult leaves.

Distribution: Restricted to the Lake King district (Roe District). Figure 9.

ECOLOGY: This species forms dense, often monospecific, thickets on sandy loams on flat or slightly low areas.

Extensive intergrades occur with E. platypus Hook., forming dense low mallet stands in country west and northwest of Ravensthorpe (these are treated as E. platypus subsp. congregata ined. by Brooker \& Kleinig 1990).

Conservation status: Not considered to be at risk.

The epithet is from the Greek gonia, an angle, and karpos, a fruit, referring to the strongly angled fruits.

Selected specimens (from 6 examined): Western Australia ( $\mathrm{N}$ to $S$ ): $4.7 \mathrm{~km}$ from Lake KingNorseman road on Pickernill Road, Brooker 8766, 18 Dec 1984 (CANB, NSW, PERTH); $17.6 \mathrm{~km}$

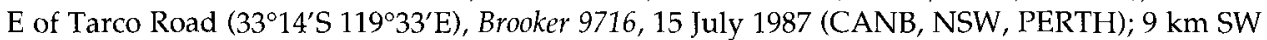
of Koornong Road on Fitzgerald Road, Foreman 1339, 29 Nov 1985 (MEL, CANB, NSW, PERTH).

Intergrades with E. platypus (from 3 examined): $5.8 \mathrm{~km} \mathrm{NW}$ of Fitzgerald Road on West River Road, Hill 2397, Johnson, Blaxell \& Brooker, 9 Nov 1986 (NSW).

11. Eucalyptus eremophila (Diels) Maiden, J. \& Proc. Roy. Soc. New South Wales 54: $71(1920)$.

BAsionym: Eucalyptus occidentalis Endl. var. eremophila Diels in Diels \& Pritzel, Bot. Jahrb. Syst. 35: 442 (1904).

TyPe CITATION: 'Hab. in distr. Coolgardie pr. Boorabbin in glareosis fl. m. Nov. (E. Pritzel Pl. Austr. occ. 917), pr. munic. Coolgardie in fruticetis apertis arenoso-lutosis flor. m. Oct. (D. 5237), in fruticetis apertis lutoso-lapidosis fl. m. Nov. pr. Gilmores (D. 5264).'

TYPE: WeSTERN Australia: near Coolgardie, L. Diels 5237 (lecto NSW, here designated). Diels cited 3 syntypes in the protologue, but Maiden recorded the above as the Type for Diels's variety (Crit. Revis. Eucalyptus 4: 176, pl. 149, Figure 7). This specimen is hence here designated as the lectotype.

Tree (mallet) to $12 \mathrm{~m}$ or mallee to $6 \mathrm{~m}$. Bark smooth, semiglossy, pale grey or silver to pale brown, yellow-brown or greenish. Juvenile leaves disjunct, broad-lanceolate to ovate, dull, grey, petiolate. Adult leaves disjunct, lanceolate, glossy, with a distinct bluish sheen from the large, translucent stomata, 4-12 cm long, 5-17 mm wide; lateral veins scattered; reticulation sparse, incomplete; oil glands crowded, spherical. Inflorescences simple, axillary; umbellasters 7-flowered; peduncles flattened, $15-30 \mathrm{~mm}$ long, to 6 $\mathrm{mm}$ wide; pedicels $4-8 \mathrm{~mm}$ long. Buds cylindrical, $20-30 \mathrm{~mm}$ long, 5-7 mm diam.; calyptra 2.5 or more times longer than hypanthium, cylindrical, apically rounded or acuminate. Stamens all fertile; filaments erect; anthers oblong, dorsifixed, dehiscing through parallel slits. Fruits ovoid to obconical, 8-13 mm long, 7-11 mm diam.; stemonophore broad, flat, persistent; disc flat; valves acicular, basally enclosed, apically exserted. Seeds ovoid, somewhat flattened, grey-brown, regularly shallowly reticulate. Figure 10. 
E. eremophila is described here under a reduced circumscription to allow comparison with segregate taxa described below.

DisTRIBUTION: Though here restricted from its most inclusive usage, this is a widespread and frequent species, extending from the Southern Wheat Belt (as far west as Lake Chinokup) through the southern and central Goldfields to the edges of the Nullarbor Plain and Great Victoria Desert. It is replaced in adjoining areas by one or other of the following three species or more locally by the partly sympatric E. incerata Brooker \& Hopper ined. Figure 11.

ECOLOGY: E. eremophila shows a wide ecological tolerance, but is absent from the lightest and heaviest soils. It tends to occur as trees of mallet form in woodlands on heavier or more calcareous soils, and as mallees in mallee shrublands on sandier soils.

Hybrids are recorded with E. grossa F. Muell. ex Benth. and (in cultivation) E. torquata Luehm. The latter is an intersectional hybrid with a member of sect. Dumaria.

Conservation Status: Widespread and abundant, not considered to be at risk.

SeleCted SPECIMENS (from 48 examined): WeSTERn Australia: $1 \mathrm{~km}$ SW of S shore of Lake Chinokup, Hill 2462, Johnson \& Blaxell, 13 Nov 1986 (NSW, PERTH); corner of Ardler Road and Old Ravensthorpe Road, L. Johnson $9082 \&$ M. Johnson, 15 May 1988 (NSW, PERTH); 7.2 miles [11.5 $\mathrm{km}$ ] E of Southern Cross, Chippendale 98, 7 Mar 1967 (CANB, NSW); Mt Short, 10 miles [16 km] N of Ravensthorpe, Wrigley, 5 Nov 1968 (CBG 030980, NSW); $33.1 \mathrm{~km}$ W of Coolgardie Norseman road on Hyden track, Hill 605, Johnson, Blaxell, Brooker \& Hopper, 7 Nov 1983 (NSW); $30.8 \mathrm{~km} \mathrm{~W}$ of highway on Griggs Road, Hill 2305, Johnson \& Blaxell, 7 Nov 1986 (NSW, PERTH); $52.1 \mathrm{~km} \mathrm{~S}$ of Norseman on highway, Hill 2234, Johnson, Blaxell \& Brooker, 5 Nov 1986 (NSW, PERTH); $109 \mathrm{~km} \mathrm{~W}$ of Balladonia on Norseman road, Brooker 6457, 22 Aug 1979 (CANB, NSW, PERTH); $22.5 \mathrm{~km} \mathrm{~W}$ of Balladonia Roadhouse on Highway 1, Hill 219 \& Johnson, 19 Oct 1983 (NSW); $8.6 \mathrm{~km}$ S of Queen Victoria Spring on Cundeelee track, Hill 2682 \& Johnson, 30 Nov 1986 (NSW); 13 miles [21 km] E of Zanthus, Brooker 2573, 18 June 1970 (PERTH, NSW).

E. eremophila x E. grossa: $23.6 \mathrm{~km}$ W of highway on Lake King road, Brooker 8844, 12 Feb 1985 (CANB, NSW, PERTH).

E. eremophila x E. torquata: Cult. Oaklands, N.S.W., O'Rourke, July 1971 (NSW).

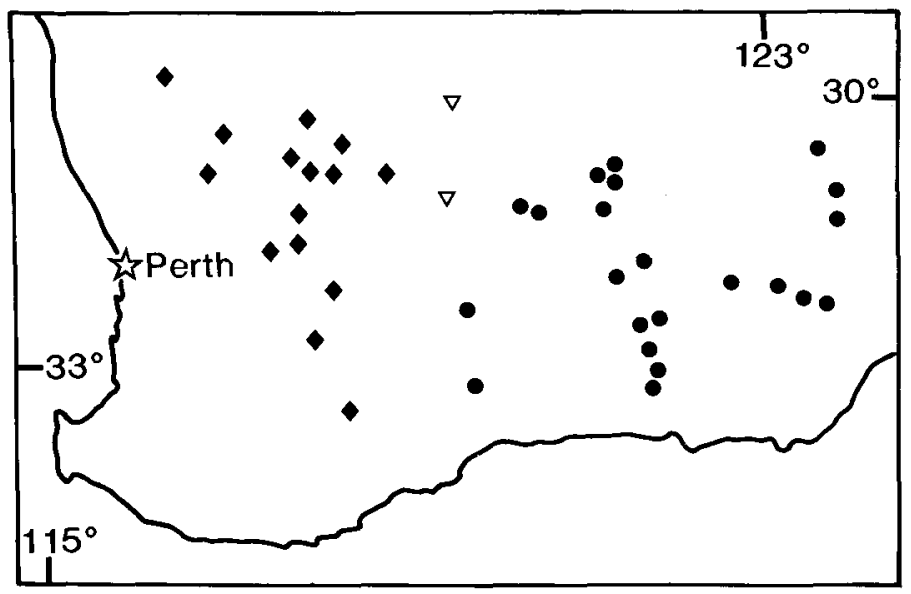

Figure 11. Distribution of E. eremophila $(\bullet)$, E. tenera $(\bullet)$ and intergrades between the two $(\nabla)$. 
12. Eucalyptus tenera L. Johnson $\mathcal{E} K$. Hill, sp. nov.

Affinis E. eremophilae sed characteribus sequentibus distinguitur: habitus et partes multi minores, umbellastrae saepissime 11-florae, pedunculi breviores gracilioresque, calyptra proportione longior acutiorque.

Type: Western Australia: Bencubbin, M.I.H. Brooker 8493, 16 Mar 1984 (holo NSW; iso AD, CANB, MEL, PERTH).

Mallee to $4 \mathrm{~m}$. Bark smooth, semiglossy, pale grey or grey to red-brown or bronze. Juvenile leaves disjunct, linear for first 3-4 nodes, then becoming lanceolate. Adult leaves disjunct, lanceolate to broad-lanceolate, glossy, with a distinct bluish sheen from the large, translucent stomata, 4-8 cm long, 7-18 mm wide; petioles 10-14 mm long; lateral veins scattered; reticulation sparse, incomplete; oil glands crowded, spherical. Inflorescences simple, axillary; umbellasters 7-11-flowered; peduncles narrowly flattened, $18-25 \mathrm{~mm}$ long, to $5 \mathrm{~mm}$ wide; pedicels 3-6 mm long. Buds cylindrical, 25-40 $\mathrm{mm}$ long, 5-7 mm diam.; calyptra 3 times or more longer than hypanthium, cylindrical, apiculate. Stamens all fertile; filaments erect; anthers oblong, dorsifixed, dehiscing by parallel slits. Fruits ovoid to obconical, 8-11 mm long, 7-10 $\mathrm{mm}$ diam.; stemonophore broad, flat, persistent; disc flat; valves acicular, basally enclosed, apically exserted. Seeds ovoid, somewhat flattened, grey-brown, regularly shallowly reticulate. Figure 10.

E. tenera is distinguished from E. eremophila by the generally smaller form and smaller parts, the frequently 11-flowered umbellasters (always 7-flowered in the latter), the shorter, thinner and narrower peduncles, and the longer buds with a relatively longer and more acute calyptra.

DistRIBUTION: Sporadically distributed over a wide area of the western and northern Wheat Belt, from Coorow to Chiddarcooping Rock, south towards Lake Chinokup. Figure 11.

ECOLOGY: Restricted to shallower, sandy soils with various other mallee species in areas where wandoo woodlands occupy the deeper soils.

Hybrids are recorded with E. erythronema sens. lat.

Conservation status: Not considered to be at immediate risk. The habitat of this species lies entirely within the Wheat Belt agricultural country, and continued degradation of that area may place the entire habitat at risk in the future.

The epithet is from the Latin tener, delicate, referring to the species having smaller and more slender parts than those of E. eremophila and E. tephroclada.

Selected specimens (from 17 examined): Western Australia ( $N$ to S): 'Doley's Farm', ESE of Coorow, Brooker 9059, 3 Nov 1985 (CANB, NSW, PERTH); $33.8 \mathrm{~km} \mathrm{~S}$ of Koorda on Wyalkatchem road, Hill 2918, 27 Aug 1988 (NSW); $28.3 \mathrm{~km}$ from Tammin on York road, Brooker 9105, 15 Nov 1985 (CANB, NSW PERTH); 9 km N of Scotsmans Road on Bimbijy Road, Brooker 8435, 25 Jan 1984 (CANB, NSW, PERTH); 2.0 km E of Dickinson Road on Nambadilling Road, Hill 2480, Johnson \& Blaxell, 15 Nov 1986 (NSW, CANB, CBG, MEL, PERTH); Chiddarcooping Nature Reserve, Brooker 7980, 11 Feb 1983 (CANB, NSW, PERTH).

E. erythronema sens. lat. x E. tenera: Kellerberrin, Vachel, Dec 1903 (NSW); 'Oxendale' farm, Barnes Road, SE of Yelbeni, Brooker 9735, 23 July 1987 (CANB, NSW, PERTH).

13. Eucalyptus tephroclada L. Johnson \& K. Hill, sp. nov.

Inter species affinitatis E. eremophilae combinatione characterum sequentium distinguitur: ramuli pruinosi, fructus parvi. 
Type: Western Australia: $6 \mathrm{~km}$ from Bruce Rock on Narembeen road, K.D. Hill 2484, L.A.S. Johnson \& D.F. Blaxell, 15 Nov 1986 (holo NSW; iso PERTH).

[Eucalyptus erythronema Turcz. var. roei Beck ex Maiden, Crit. Revis. Eucalyptus 1: 110 (1904); in syn., nom. nud.; in part]

Mallee to $5 \mathrm{~m}$. Bark smooth, semiglossy, dark grey to red-brown or bronze. Branchlets pruinose. Juvenile leaves disjunct, lanceolate to broad-lanceolate, dull, grey, petiolate. Adult leaves disjunct, lanceolate, glossy, with a distinct bluish sheen from the large, translucent stomata, 4-10 cm long, 7-19 mm wide; pedicels flattened, 6-16 mm long; lateral veins scattered; reticulation sparse, incomplete; oil glands crowded, spherical. Inflorescences simple, axillary; umbellasters 7-11-flowered; peduncles terete or narrowly flattened; $17-30 \mathrm{~mm}$ long, to $3 \mathrm{~mm}$ wide; pedicels $4-10 \mathrm{~mm}$ long. Buds cylindrical, 18-35 mm long, 5-7 mm diam.; calyptra 2.5 or more times longer than hypanthium, cylindrical, apically rounded. Stamens all fertile; filaments erect; anthers oblong, dorsifixed, dehiscing through parallel slits. Fruits ovoid to obconical, $8-11 \mathrm{~mm}$ long, 7-10 mm diam.; stemonophore broad, flat, persistent; disc flat; valves acicular, basally enclosed, apically exserted. Seeds ovoid, somewhat flattened, grey-brown, regularly shallowly reticulate. Figure 12 .

Distinguished within the E. eremophila group by the pruinose branchlets and the small fruits. The related E. incerata Brooker \& Hopper ined. (another member of the E. eremophila group) shares the bronze or coppery bark and glaucous branchlets, but has larger buds and fruits (buds 6-8 mm diam., fruits $10-14 \mathrm{~mm}$ long), and tends to be heavily rather than lightly pruinose. The two taxa also show a replacement distribution.

DISTRIBUTION: Sporadic and scattered in the area between Quairading, Southern Cross, Kukerin and Hyden (Avon and Roe Districts). This is now all largely cleared agricultural country. Figure 13.

ECOLOGY: Restricted to local mallee scrubs on usually shallow and sandy soils, over various substrates in otherwise woodland country.

Hybrids are recorded with E. cylindriflora Maiden \& Blakely and E. erythronema.

CONSERVATION STATUS: 3V?C. The habitat has been seriously reduced by agricultural clearing.

The epithet is from the Greek tephros, ash-grey, and klados, a twig, referring to the pruinose branchlets.

SELECTED SPECIMENS (from 19 examined): Western Australia ( $\mathrm{N}$ to S): c. 5 miles [ $8 \mathrm{~km}$ ] E of Bodallin, Johnson W 130, 16 Dec 1960 (NSW); 3 km W of Hyden, Strid 21940, 31 Dec 1982 (NSW); 6 km NW of Jitarning, Foreman 1139, 21 Nov 1985 (MEL, AD, CANB, NSW, PERTH); Harrismith, Gardner 2118, 6 Mar 1924 (PERTH, NSW).

E. cylindriflora x E. tephroclada: $22 \mathrm{~km} \mathrm{SE}$ of Pingaring, Haegi 1083, 21 Sep 1976 (AD, NSW, PERTH).

E. erythronema x E. tephroclada: Noongar, Chippendale 286, 13 Aug 1967 (CANB, NSW).

\section{Eucalyptus depauperata L. Johnson $\&$ K. Hill, sp. nov.}

Inter species affinitatis E. eremophilae combinatione sequenti characterum distinguitur: habitus pluricaulis et fruticosus; folia adulta, alabastra et fructus minores.

Type: Western Australia: $1.6 \mathrm{~km} \mathrm{~N}$ of Hayes Road on North Road, K.D. Hill 3027, 1 Aug 1988 (holo NSW; iso CANB, PERTH).

[Eucalyptus sp. E of Brooker \& Kleinig (1990)] 


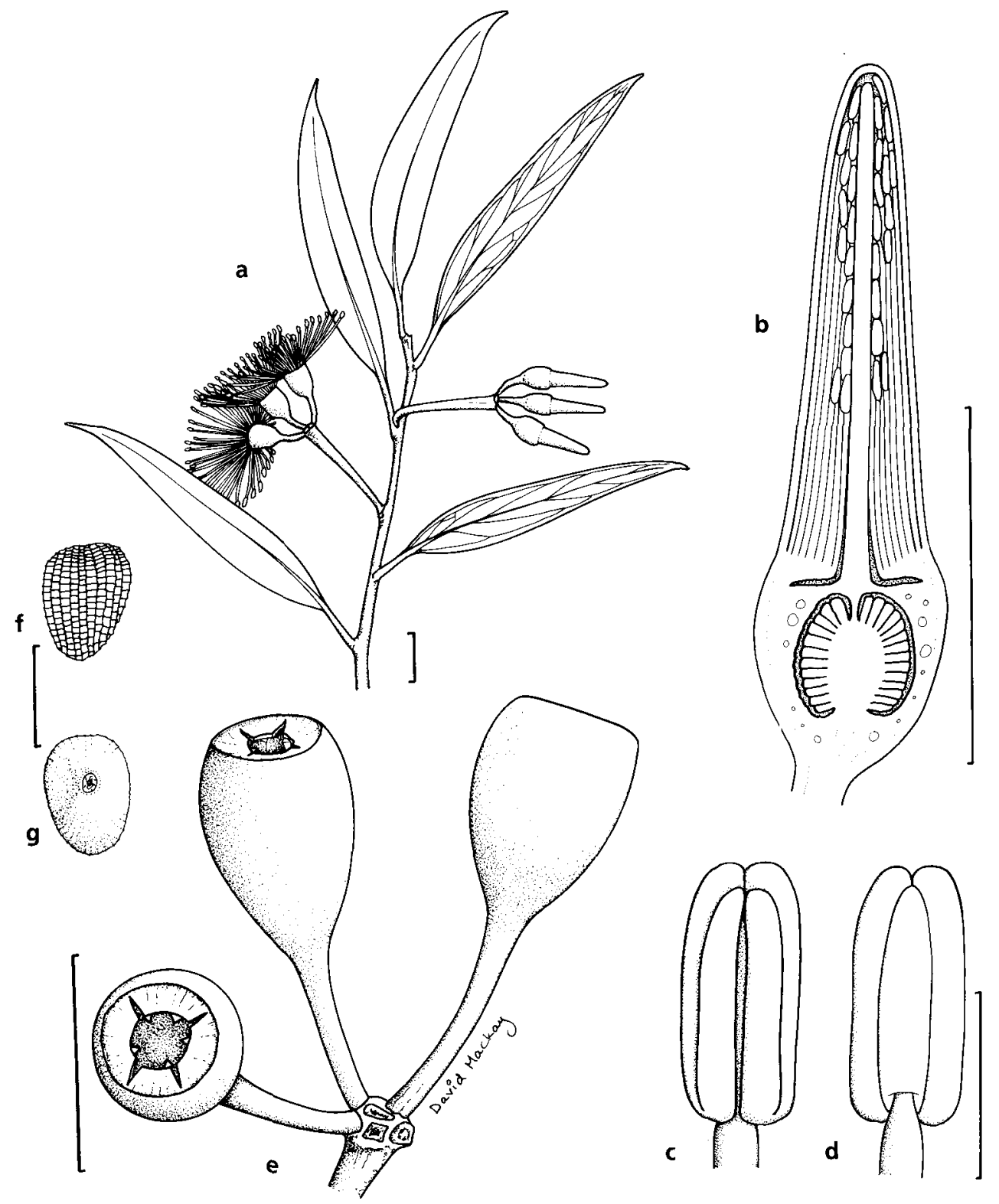

Figure 12. E. tephroclada. a, adult leaves, flowers and buds; $\mathbf{b}$, section of bud; $\mathbf{c}, \mathbf{d}$, anther; $\mathbf{e}$, fruits; $\mathbf{f}, \mathbf{g}$, seed (all from Strid 21940). Scale bar: a, b, e = $1 \mathrm{~cm} ; \mathrm{c}, \mathrm{d}, \mathrm{f}, \mathrm{g}=1 \mathrm{~mm}$. 


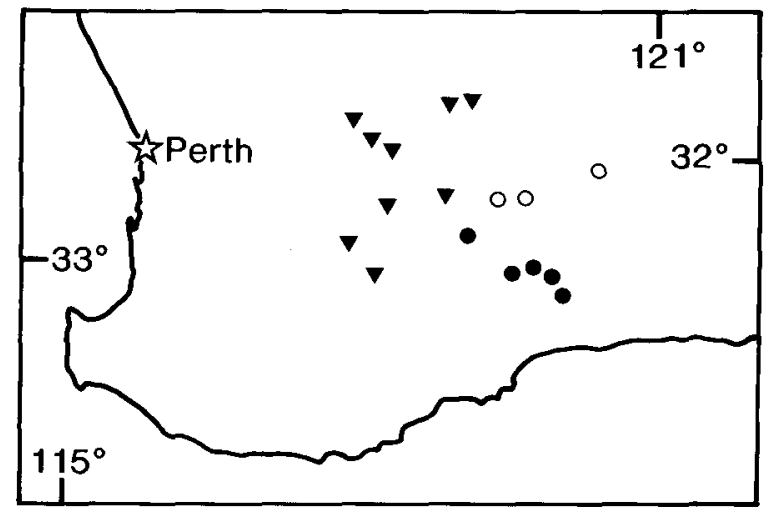

Figure 13. Distribution of E. tephroclada $(\mathbf{\nabla})$, E. incerata $(O)$ and E. depauperata $(\bullet)$.

Mallee to $4 \mathrm{~m}$. Bark smooth, semiglossy, pale grey or silver to pale brown. Juvenile leaves disjunct, lanceolate. Adult leaves disjunct, narrow-lanceolate to lanceolate, glossy, often with a distinct bluish sheen from the large, translucent stomata, 3-7 cm long, 5-12 mm wide; petioles $8-11 \mathrm{~mm}$ long; lateral veins scattered; reticulation sparse, incomplete; oil glands crowded, spherical. Inflorescences simple, axillary; umbellasters 7-flowered; peduncles 8-25 mm long; pedicels 3-5 $\mathrm{mm}$ long. Buds cylindrical, 16-21 mm long, 5-6 mm diam.; calyptra 2.5 times or more longer than hypanthium, cylindrical, apically rounded. Stamens all fertile; filaments erect; anthers oblong, dorsifixed, dehiscing through parallel slits. Fruits ovoid to obconical, $8-10 \mathrm{~mm}$ long, 6-8 mm diam.; stemonophore broad, flat, persistent; disc flat; valves acicular, basally enclosed, apically exserted. Seeds ovoid, somewhat flattened, grey-brown, regularly shallowly reticulate. Figure 14.

Distinguished within the E. eremophila group by the small leaves, buds and fruits. It is also usually a small, slender 'whipstick' mallee in contrast to the more robust habit of other members of the E. eremophila complex.

DistRIBUTION: Locally frequent in the area around Lake King, extending northwest towards Pingaring (Roe District). Figure 13.

ECOLOGY: Occurs in mixed mallee shrublands, on lateritic sand or sandy loam.

Hybrids are recorded with E. grossa F. Muell. ex Benth. and E. suggrandis subsp. alipes.

CONSERVATION STATUS: 2R. Substantial populations occur in relatively undeveloped country. Future development could, however, threaten this species.

The epithet is from the mediaeval Latin depauperatus, made poor, referring to the generally smaller parts and lower stature than those of E. eremophila and its other close allies.

Selected specimens (from 7 examined): Western Australia ( $W$ to E): $4.2 \mathrm{~km}$ S of Varley Road on track to Dragon Rock, Hill 2469, Johnson \& Blaxell, 14 Nov 1986 (NSW, PERTH); $52 \mathrm{~km} \mathrm{~N}$ of Ravensthorpe on Hatters Hill Road, Hill 319, Johnson \& Blaxell, 22 Oct 1983 (NSW); $13.6 \mathrm{~km} \mathrm{~S}$ of Lake King-Norseman road on Hatters Hill Road, Brooker 8177, 7 June 1983 (CANB, NSW, PERTH); $4.5 \mathrm{~km} \mathrm{~W}$ of rabbit-proof fence east of Lake King, Brooker 8848, 12 Feb 1985 (CANB, NSW, PERTH). 


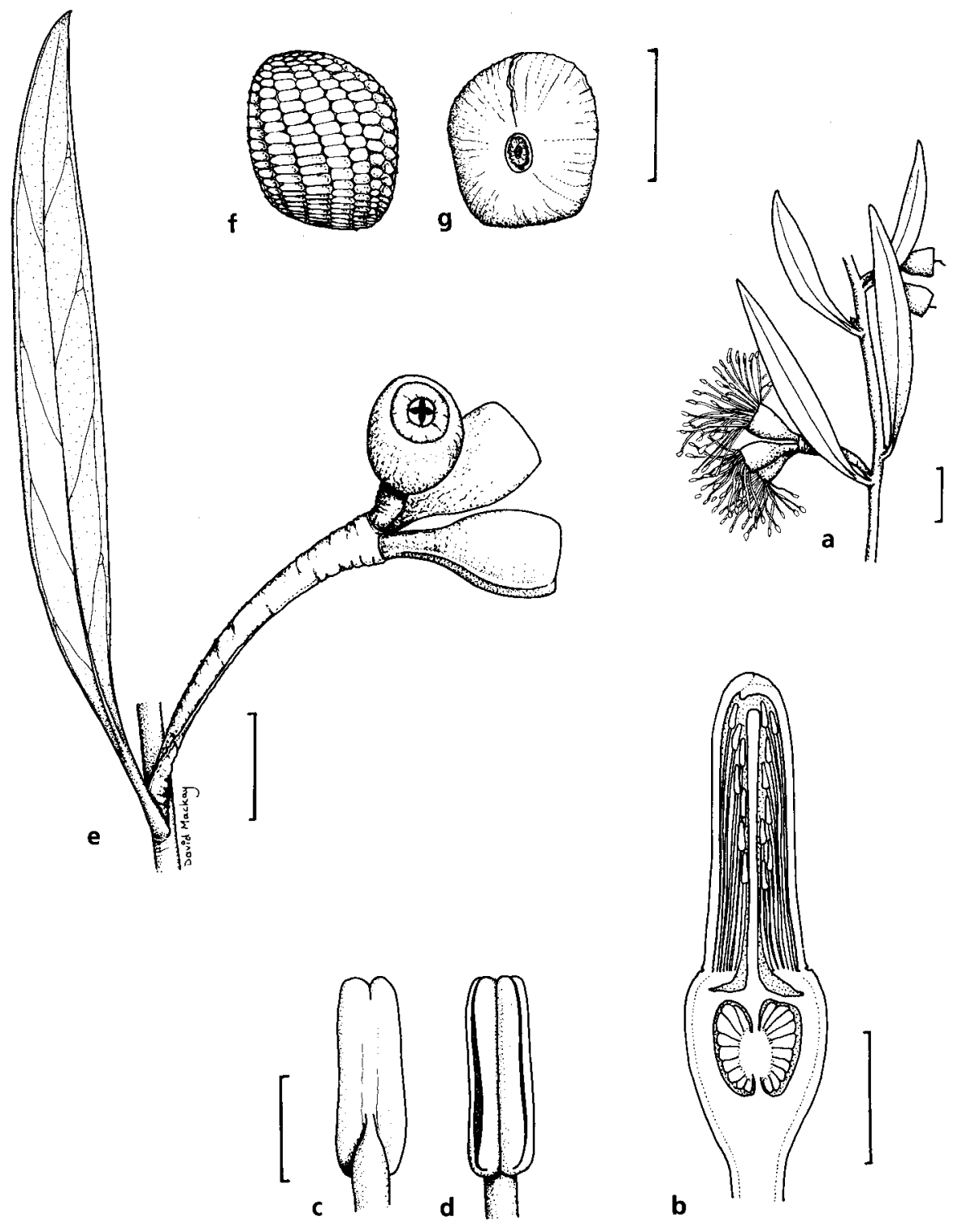

Figure 14. E. depauperata. $\mathbf{a}$, adult leaves and flowers; $\mathbf{b}$, section of bud; $\mathbf{c}, \mathbf{d}$, anther; $\mathbf{e}$, adult leaf and fruits; $\mathbf{f}, \mathbf{g}$, seed $(\mathbf{a}, \mathbf{c}, \mathbf{d}, \mathbf{e}, \mathbf{f}, \mathbf{g}$ from Hill 319, Johnson \& Blaxell, $\mathbf{b}$ from Brooker 8177). Scale bar: $\mathrm{a}, \mathrm{e}=1 \mathrm{~cm} ; \mathrm{b}=5 \mathrm{~mm}$; $, \mathrm{d}, \mathrm{f}, \mathrm{g}=1 \mathrm{~mm}$. 
E. depauperata x E. grossa: $17.7 \mathrm{~km}$ W of Lake King, Hill 2391, Johnson, Blaxell \& Brooker, 9 Nov 1986 (NSW).

E. depauperata $\times$ E. suggrandis subsp. alipes: $13.6 \mathrm{~km} \mathrm{~S}$ of Lake King-Norseman road on Hatters Hill Road, Brooker 8177, 7 June 1983 (CANB, NSW, PERTH).

\section{Series Cneorifoliae}

Species 15 to 19 are placed in series Cneorifoliae, defined by the combination: pith glands absent; filaments inflexed or irregularly flexed; anthers globoid to reniform, basifixed, subversatile, dehiscing by broad, angled slits; seeds shallowly reticulately pitted, dorsiventrally compressed.

\section{Eucalyptus phylacis L. Johnson \& K. Hill, sp. nov.}

Affinis $E$. decipienti sed inter affinitatem illae combinatione sequenti characterum distinguitur: folia lanceolata; alabastra mediocria, ovoidea et non constricta; calyptra hypanthium aequans, conica; stylus brevis, rectus; fructus breviter pedicellati; pedunculus longus.

Type: Western Australia: Meelup, east side of Cape Naturaliste $\left(33^{\circ} 35^{\prime} \mathrm{S}, 115^{\circ} 01^{\prime} \mathrm{E}\right)$, D.F. Blaxell 2000, L.A.S. Johnson E M.I.H. Brooker, 31 May 1983 (holo NSW; iso CANB, $\mathrm{K}$, PERTH).

\section{[Eucalyptus sp. K of Brooker \& Kleinig (1990)]}

Tree to $5 \mathrm{~m}$. Bark persistent on trunk and large branches, rough, coarsely flaky, light grey-brown; outer branches smooth. Juvenile leaves disjunct, blue-grey, ovate to orbicular, to $5 \mathrm{~cm}$ long, $4 \mathrm{~cm}$ wide. Adult leaves disjunct, lanceolate to broad lanceolate, acute or acuminate, falcate, dull, 6-13 cm long, 11-30 mm wide; petioles channelled above, $7-16 \mathrm{~mm}$ long; lateral veins at $30-45^{\circ}$ to midrib, \pm closely spaced, regular, densely reticulate between; intramarginal vein distinct, $0.5-1.5 \mathrm{~mm}$ from margin. Umbellasters axillary, 7-11-flowered; peduncles terete, 7-11 $\mathrm{mm}$ long; pedicels terete, 1-2 mm long. Mature buds ovoid, 8-10 mm long, 4-5 mm diam.; calyptra conical, convex, obtuse, \pm as long as hypanthium. Fruits cup-shaped or hemispherical, 3-4locular, 5-7 mm long, 7-9 mm diam.; calyptra scar raised, angled incurved at c. $45^{\circ}$, c. $0.5 \mathrm{~mm}$ wide; disc \pm flat, convex, $1.5-2.0 \mathrm{~mm}$ wide (with distinctive radial cracks crossing disc, scar and hypanthium caused by subsequent internal growth of fruit); style persistent, frequently remaining attached to one valve in open fruits; valves enclosed at base, vertically exserted, triangular. Figure 15.

Distinguished within the E. decipiens Endl. group by the following combination of characters: Juvenile leaves obtuse to rounded (not emarginate); adult leaves lanceolate; buds medium to large ( $8 \mathrm{~mm}$ long, $5 \mathrm{~mm}$ diam.), ovoid, not constricted; calyptra about as long as hypanthium, conical, convex; style short, straight, tip shallowly engaged in calyptra; fruits pedicellate (pedicel 1-2 $\mathrm{mm}$ long); peduncle to $12 \mathrm{~mm}$. long. The widespread E. decipiens is distinguished by the emarginate juvenile leaves, and the apparently closely related rare species $E$. balanites Grayling \& Brooker ined. is distinguished by the rounded calyptra which is narrower than the hypanthium, and the larger buds (to $10 \mathrm{~mm}$ long).

Distribution: Discovered by Dr Neville Marchant of the Western Australian Herbarium, E. phylacis is known only from a single population in the Cape Naturaliste area in the far south-west (Menzies District). Figure 16.

ECOLOGY: Localised and not frequent, in a patch of mallee-heath country on undulating laterite, in an open area in otherwise E. calophylla Lindley - E. marginata Sm. woodland. 

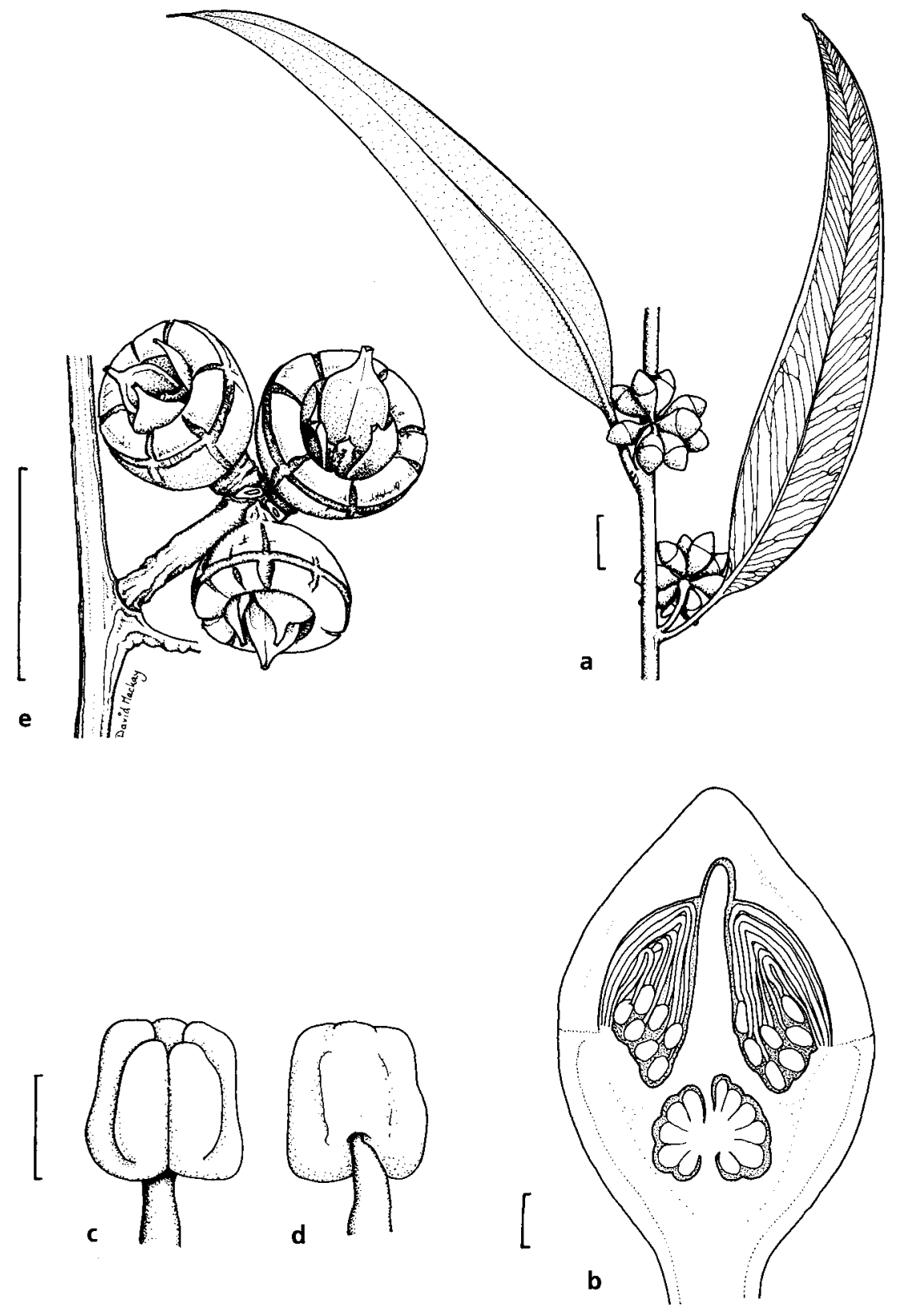

Figure 15. E. phylacis. a, adult leaves and buds; $\mathbf{b}$, section of bud; $\mathbf{c}$, $\mathbf{d}$, anther; $\mathbf{e}$, fruits (all from Blaxell 2000). Scale bar: $\mathrm{a}, \mathrm{e}=1 \mathrm{~cm} ; \mathrm{b}=1 \mathrm{~mm} ; \mathrm{c}, \mathrm{d}=0.5 \mathrm{~mm}$. 
CONSERVATION STATUS: $2 \mathrm{~V}$-. Known only from the type area, where the population has already been damaged by roadworks.

The specific epithet is from the Greek phylakis, a watcher or guard (female), referring to its occurrence on a hill overlooking the ocean. The feminine word (masculine equivalent phylax) is chosen to agree with the gender of Eucalyptus, but the word is a noun and not subject to change with a change of generic association. The ' $y$ ' is short as in 'lyrical', the stress is on the first syllable, and the ' $c$ ' is soft in modern usage.

Selected specimens (from 7 examined): Western Australia ( $\mathrm{N}$ to S): $2 \mathrm{~km} \mathrm{~S}$ of Meelup, Hill 3074 $A$, 4 Sep 1988 (NSW); $0.9 \mathrm{~km}$ from Cape Naturaliste road on Meelup road, Johnson $9133 \mathcal{E} B$. Briggs, 26 Oct 1988 (NSW, CANB); hilltop $2 \mathrm{~km} \mathrm{~S}$ of Meelup Beach, Marchant 84/102, 14 Nov 1984 (PERTH, NSW).

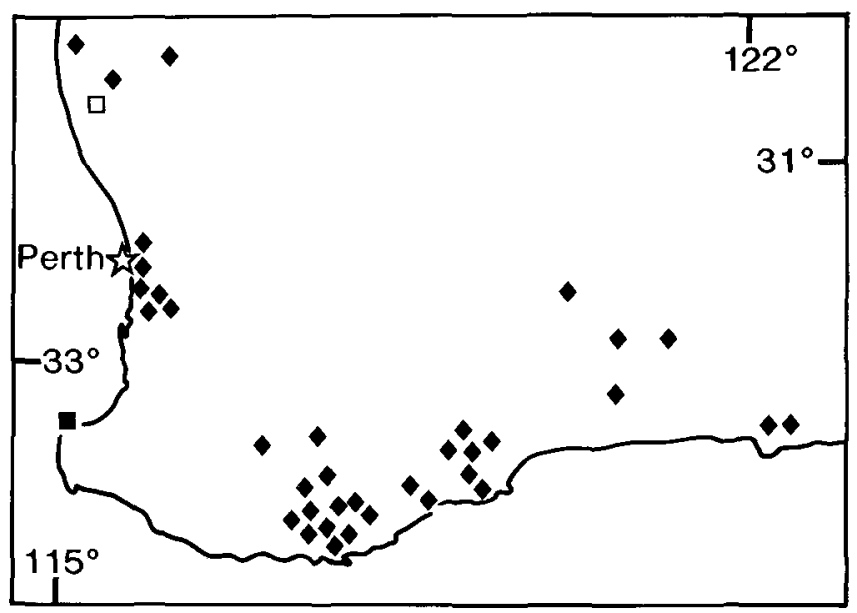

Figure 16. Distribution of E. phylacis (๘), E. balanites ( $\square$ ), E. decipiens ( $\bullet$ ).

\section{Eucalyptus misella L. Johnson $\mathcal{E} K$. Hill, sp. nov.}

Affinis E. angustissimae sed characteribus sequentibus distinguitur: folia adulta latiora, non nitida et faciebus similioribus; folia juvenilia latiora; fructus obconici in pedunculis pedicellisque longioribus crassioribusque; calyptra brevior, plus rotundata et quam hypanthio angustior.

TyPe: Western Australia: $11.9 \mathrm{~km}$ N of Rollands Road along Fields Road North, $\mathrm{W}$ of Grasspatch ( $\left.33^{\circ} 08^{\prime} \mathrm{S}, 121^{\circ} 11^{\prime} \mathrm{E}\right)$, K.D. Hill 302, L.A.S. Johnson \& D.F. Blaxell, 22 Oct 1983 (holo NSW; iso CANB, K, PERTH).

[Eucalyptus sp. L of Brooker \& Kleinig (1990)]

Mallee to $2.5 \mathrm{~m}$, often less. Foliage dense, extending to ground. Bark smooth throughout, dull, grey. Seedling leaves opposite for 5-6 nodes, linear, \pm sessile. Juvenile leaves disjunct, lanceolate, \pm sessile, to $5 \mathrm{~mm}$ wide. Adult leaves disjunct, similifacial, lanceolate to broad-lanceolate, dull, bluish, 5-9 cm long, 8-16 mm wide; petioles to 8 $\mathrm{mm}$ long, broad, flattened; lateral veins moderately spaced, \pm regular, at $40^{\circ}-50^{\circ}$ to midrib; oil glands large, \pm dense; intramarginal vein \pm obscure, $0.5-1.0 \mathrm{~mm}$ from margin. Inflorescences simple, axillary; umbellasters 7-flowered; peduncles terete, thick, 3-5 $\mathrm{mm}$ long, to $3 \mathrm{~mm}$ thick; pedicels thick, angular, $2 \mathrm{~mm}$ long, tapering into hypanthium. Mature buds ovoid, 5-7 $\mathrm{mm}$ long, 4-5 mm diam.; calyptra hemispherical or 


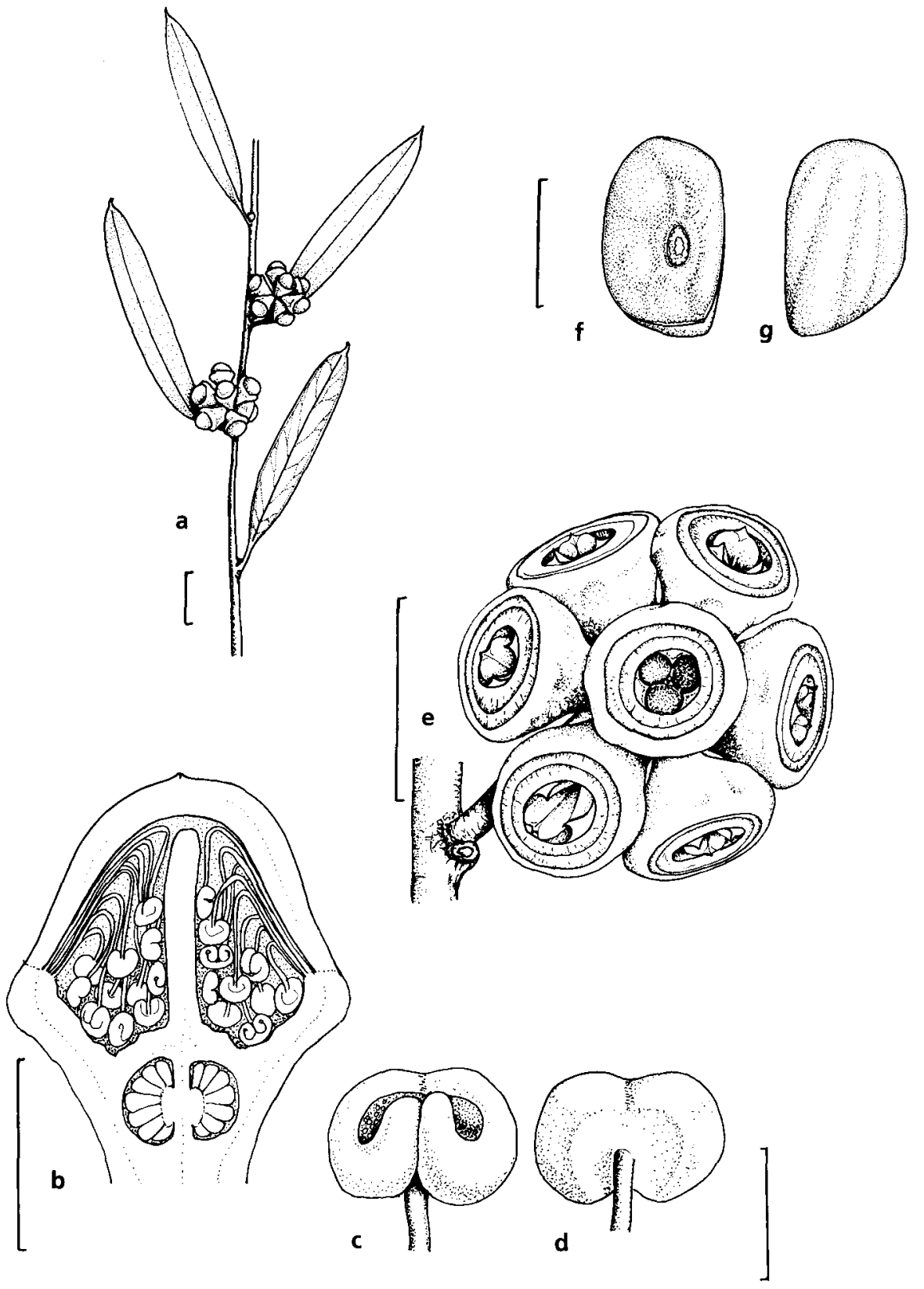

Figure 17. E. misella. $\mathbf{a}$, adult leaves and buds; $\mathbf{b}$, section of bud; $\mathbf{c}, \mathrm{d}$, anther; $\mathbf{e}$, fruits; $\mathrm{f}, \mathrm{g}$, seed (all from Hill 302, Johnson $\mathcal{E}$ Blaxell). Scale bar: $\mathrm{a}, \mathrm{e}=1 \mathrm{~cm} ; \mathrm{b}=3 \mathrm{~mm} ; \mathrm{f}, \mathrm{g}=1 \mathrm{~mm} ; \mathrm{c}, \mathrm{d}=0.5 \mathrm{~mm}$. 
slightly higher, sometimes finely apiculate, about as long as hypanthium, distinctly narrower than hypanthium. Fruits broadly obconical to almost cup-shaped, usually 3locular, 5-6 mm long, 6-8 mm diam; calyptra scar flat, c. $0.2 \mathrm{~mm}$ wide; stemonophore expanded by tissue expansion within the hypanthium after flowering, flat, 0.5-1.0 $\mathrm{mm}$ wide; disc flat, $0.5-1.0 \mathrm{~mm}$ wide; valves broadly triangular, obtuse, apically rim level, flat, with small dorsal protuberances. Seeds semiglossy, pale red-brown, flattened, elliptic, regularly very shallowly reticulate (almost smooth); hilum ventral; chaff similar. Figure 17.

E. misella differs from E. angustissima F. Muell. in the broader, dull, more similifacial adult leaves, the broader juvenile leaves, the generally larger, obconical fruits on longer, thicker peduncles and pedicels, and the shorter, more rounded calyptra that is distinctly narrower than the hypanthium. The very similar E. foliosa (below) has greener, narrower leaves and slightly more delicate fruits than E. misella, and occurs in a quite different habitat, viz. on saline samphire flats.

Distribution: Known only from a small area west of Grasspatch in the Esperance district. Figure 18.

ECOLOGX: Locally abundant in flat, low-lying grey or white sand-plain heath country, with Eucalyptus tetragona (R. Br.) F. Muell., Eucalyptus uncinata Turcz., E. incrassata Labill. (sens. lat.), E. leptocalyx Blakely, E. perangusta Brooker, E. dolichorhyncha (Brooker) Brooker \& Hopper ined. and E. tumida Brooker \& Hopper.

CONSERVATION STATUS: 2R.

The epithet is from the Latin misellus, wretched, in reference to the often low growth of this species.

Selected specimen (from 5 examined): Western Australia: $12.3 \mathrm{~km} \mathrm{~N}$ from Rollands Road on Fields Road North, Hill 2309, Johnson \& Blaxell, 7 Nov 1986 (NSW).

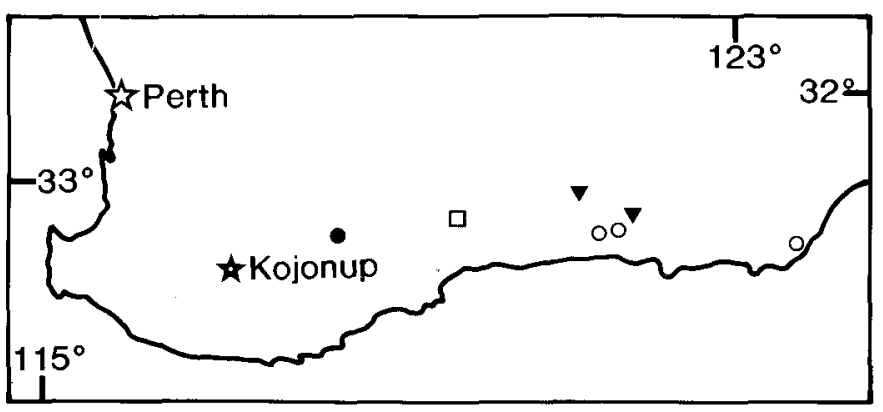

Figure 18. Distribution of E. misella ( $\mathbf{\nabla})$, E. angustissima subsp. angustissima (O), subsp. quaerenda $(\bullet)$ and intergrades between the two subspecies $(\square)$.

17. Eucalyptus foliosa L. Johnson $\mathcal{E} K$. Hill, sp. nov.

Affinis et simillima E. misellae sed characteribus sequentibus et habitatione distincta distinguitur: folia adulta angustiora, virides et aliquanto nitentiores; fructus aliquanto minores in pedicellis gracilioribus; statura saepissime major. 
TyPE: WeStern Australia: $2 \mathrm{~km}$ W of Norseman-Esperance road on Griffiths Road ( $33^{\circ} 29^{\prime}$ S, $121^{\circ} 44^{\prime}$ E), K.D. Hill 2299, L.A.S. Johnson, M.I.H. Brooker \& D.F. Blaxell, 7 Nov 1986 (holo NSW; iso CANB, MEL, PERTH).

Mallee to $4 \mathrm{~m}$. Foliage dense, extending to ground. Bark smooth throughout, dull, grey. Seedling leaves opposite for 5-6 nodes, linear, \pm sessile. Adult leaves disjunct, narrowlanceolate, green, semiglossy, 4-8 cm long, 5-10 mm wide; petioles to $10 \mathrm{~mm}$ long, broad, flattened; lateral veins moderately spaced, \pm regular, at $30^{\circ}-50^{\circ}$ to midrib; oil glands large, \pm dense; intramarginal vein \pm conspicuous, $0.5-1.0 \mathrm{~mm}$ from margin. Inflorescences simple, axillary; umbellasters 7-flowered; peduncles terete, $2-5 \mathrm{~mm}$ long, to $2 \mathrm{~mm}$ thick; pedicels angular, $2 \mathrm{~mm}$ long, $1.5 \mathrm{~mm}$ thick, tapering into hypanthium. Mature buds ovoid, 5-7 mm long, 4-5 mm diam.; calyptra hemispherical or slightly longer, often broadly pointed, about as long as hypanthium, distinctly narrower than hypanthium. Fruits broadly obconical to almost cup-shaped, usually 3locular, 5-6 mm long, 6-7 $\mathrm{mm}$ diam.; calyptra scar flat, c. $0.2 \mathrm{~mm}$ wide; stemonophore slightly expanded by post-flowering growth within the hypanthium, flat or slightly raised, to $0.5 \mathrm{~mm}$ wide; disc flat or slightly raised, $0.5-1.0 \mathrm{~mm}$ wide; valves broadly triangular, obtuse, apically rim level, flat, with small dorsal protuberances. Seeds semiglossy, pale red-brown, flattened, elliptic, regularly very shallowly reticulate (almost smooth); hilum ventral; chaff similar. Figure 19.
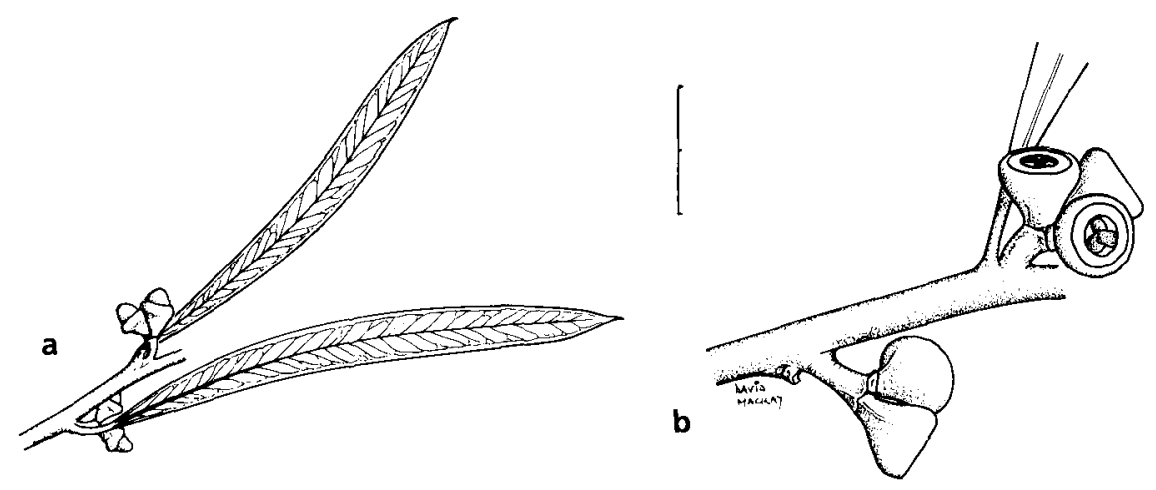

Figure 19. E. foliosa. a, adult leaves and buds; b, fruits (all from Hill 2299, Johnson, Blaxell \& Brooker). Scale bar $=1 \mathrm{~cm}$.

E. foliosa differs from E. misella in the narrower, green and somewhat glossier adult leaves, and the slightly smaller fruits on more slender peduncles. $E$. foliosa also frequently grows taller. Both taxa differ from E. angustissima in the broader, more similifacial leaves, the larger buds and fruits, and the distinctly constricted buds.

Distribution: This species is known only from a small area around Scaddan and Gibson, north of Esperance.

ECOLOGY: Locally abundant on often wet and saline low-lying grey or white sandy flats adjacent to salt lakes, with E. rigens Brooker, E. uncinata Turcz., E. halophila D. Carr \& S. Carr, and samphires.

CONSERVATION STATUS: $2 \mathrm{R}$.

The epithet is from the Latin foliosus, leafy, referring to the dense and often deep leafy crown. 
Selected specimens (from 6 examined): Western Australia (W to E): $2.0 \mathrm{~km} \mathrm{~N}$ of Gibsons Soak on highway, Hill 2293, Johnson, Blaxell \& Brooker, 7 Nov 1986 (NSW); $6.7 \mathrm{~km}$ E of Highway on Scaddan Road, Hill 2302, Johnson, Blaxell \& Brooker, 7 Nov 1986 (NSW).

18. Eucalyptus angustissima F. Muell., Fragm. 4: 25 (1863).

Type Citation: 'Inter promontoria Point Malcolm et Point Dover. Mxw.'

Type: Western Australia: between Point Malcolm and Point Dover, G. Maxwell (holo $\mathrm{MEL}$; iso $\mathrm{K})$.

Mallee to $4 \mathrm{~m}$. Bark smooth, dull, pale grey or cream, shedding in partly adherent sheets. Juvenile leaves opposite, becoming disjunct, linear to narrow-lanceolate, grey. Adult leaves disjunct, linear to narrow-lanceolate, $4.5-13 \mathrm{~cm}$ long, 2-7 mm wide; petioles 2-5 mm long; lateral veins obscure; oil glands densely packed, spherical. Inflorescences simple, axillary; umbellasters 7 -flowered; peduncles terete or angular, 1-4 mm long; pedicels 1-2 mm long. Buds ovoid, 4-6 mm long, 3-5 mm diam.; calyptra as long as hypanthium, hemispherical, apiculate, narrower than hypanthium. Stamens all fertile; filaments regularly inflexed; anthers basifixed, subversatile, flattened globoid, dehiscing through short, angled slits. Fruits hemispherical to broadly obconical, 3-4locular, 4-7 mm long, 5-8 mm diam.; calyptra scar flat, c. $0.2 \mathrm{~mm}$ wide; stemonophore slightly expanded, flat or slightly raised, to $0.5 \mathrm{~mm}$ wide; disc flat or slightly raised, $0.5-1.0 \mathrm{~mm}$ wide; valves broadly triangular, obtuse, apically rim level, flat, with small dorsal protuberances. Seeds semiglossy, pale red-brown, flattened, elliptic, regularly very shallowly pitted and grooved (almost smooth); hilum ventral; chaff similar.

This taxon is readily distinguished within section Cneorifoliae by the extremely narrow adult leaves.

Locally frequent on saline flats in low areas.

Two subspecies are recognised on regional differences in leaf width.

1 Adult leaves less than $3 \mathrm{~mm}$ wide 18a. subsp. angustissima

$1^{*}$ Adult leaves more than $4 \mathrm{~mm}$ wide 18b. subsp. quaerenda

\section{8a. Eucalyptus angustissima $F$. Muell. subsp. angustissima}

Adult leaves linear, 7-13 cm long, 2-3 mm wide. Buds 5-6 mm long, 4-5 mm diam. Fruits 5-7 mm long, 5-8 mm diam. Figure 20.

Distribution: Two disjunct occurrences are known, one north of Esperance and west of the Scaddan-Grasspatch area, and one near Israelite Bay (Eyre District). Figure 18.

ECOLOGY: This taxon has a patchy and sporadic distribution, forming open shrublands with Melaleuca spp. and with grass and sedge understorey on saline flats and around saltpans.

Conservation status: 3RC (Briggs \& Leigh 1988: 118).

SElected SPECIMENS (from 11 examined): Western Australia (W to E): $4.8 \mathrm{~km} \mathrm{~N}$ from end of made

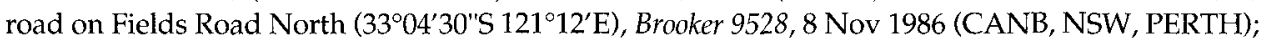
$16.1 \mathrm{~km}$ W of highway on Speddingup Road West (Dalyup River), Hill 2296, Johnson, Blaxell $\mathcal{E}$ Brooker, 7 Nov 1986 (NSW, PERTH); $10 \mathrm{~km}$ SW of Israelite Bay on track, Crisp 4898, 7 Jan 1979 (CBG, CANB, NSW, PERTH). 
18b. Eucalyptus angustissima F. Muell. subsp. quaerenda L. Johnson $\mathcal{E}$ K. Hill, subsp. nov.

Ab subspecie typica foliis adultis brevioribus et latioribus etiam planis, alabastris fructibusque minoribus et hypanthio conico praesertim in fructibus differt.

TyPe: Western Australia: 100 metres S of the south shore of Lake Chinokup, K.D. Hill 2460, L.A.S. Johnson \& D.F. Blaxell, 13 Nov 1986 (holo NSW; iso CANB, CBG, MEL, PERTH).

Adult leaves linear to narrow-lanceolate, $4.5-9 \mathrm{~cm}$ long, 4-7 mm wide. Buds 4-5 mm long, 3-4 mm diam. Fruits 4-6 mm long, 5-7 mm diam. Figure 20.

Subspecies quaerenda differs from subspecies angustissima in the shorter, broader, flat adult leaves, the smaller buds and fruits and the conical hypanthium (especially in fruits).

DisTRIBUTION: The type form is at present known from the type area only, around the southern and western edges of Lake Chinokup (Figure 18). An early collection by Muir is cited from 'towards the Tone River', the exact locality for which is obscure. It seems unlikely that a member of this group would occur in the wetter country where the Tone River joins the Warren River. The Tone River rises to the northeast near Kojonup, in country approaching a more likely range of habitats. This area has suffered widespread and thorough devastation of native flora during the development of the wheat-farming industry, and this subspecies may have suffered severe reduction of range.

ECOLOGY: A taxon of sand-plain heath on poorly drained, somewhat saline substrates.

Intergrading populations occur with subsp. angustissima in country north of Ravensthorpe.

CONSERvation STATUS: 2V-. Known at present only from around the southern and western shore of Lake Chinokup.

The epithet is from the Latin quaerendus, to be sought, applied first at a stage in our investigations when only the early Muir collection was known, but still apt since there are few known localities.

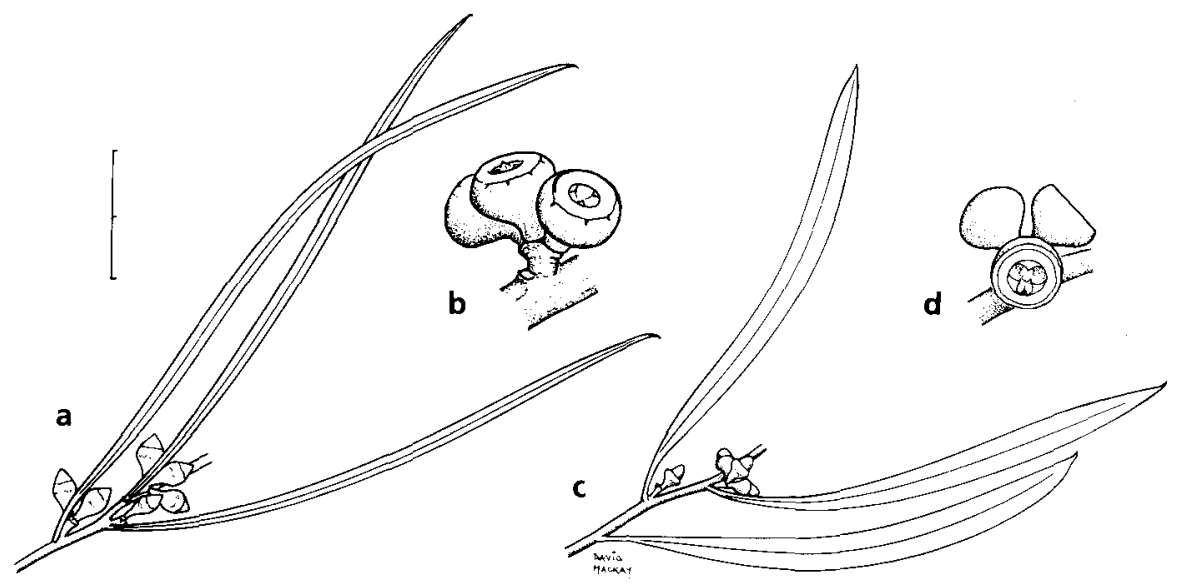

Figure 20. E. angustissima subsp. angustissima. a, adult leaves and buds; $\mathbf{b}$, fruits (aIl from Hill 2296 et al.). Subsp. quaerenda. c, adult leaves and buds; d, fruits (all from Hill 2460 et al.). 
Selected specimens (from 4 examined): Western Australia (W to E): towards the Tone River, Muir, 1880 (NSW, MEL); $8.7 \mathrm{~km} \mathrm{~N}$ of Katanning-Pingrup road on Chinocup Road, Brooker 9566, 27 Jan 1987 (CANB, NSW, PERTH).

Intergrades between subspecies (from 3 examined): Western Australia: $3.1 \mathrm{~km}$ from highway on Fitzgerald Road, Brooker 8807, 18 Jan 1985 (CANB, NSW, PERTH).

19. Eucalyptus mannensis Boomsma, Trans. \& Proc. Roy. Soc. South Australia 88: 115, pl. 1, Figure 1 (1964).

TYPe citation: 'Holotypus - Northern Territory, 20.3 miles north of Angas Downs Head Station, 15.x.1957, G. Chippendale and L. Johnson 3986 (AD 95951147). Isotypes in N.T., N.S.W., Canb., Bri., Melb., N.E.K., Perth. [sic]'

Mallee to $7 \mathrm{~m}$, often less, sometimes small tree to $8 \mathrm{~m}$. Bark persistent, fibrous-flaky on lower stems, smooth above, grey, cream or pinkish red. Juvenile leaves disjunct, lanceolate, dull, grey-green, petiolate, 5-10 cm long, 10-25 mm wide. Adult leaves disjunct, lanceolate, acuminate, glossy, with abundant oil glands (oil glands black in dried leaves), 6-15 cm long, 8-19 mm wide; petioles 9-17 $\mathrm{mm}$ long; lateral veins moderately closely-spaced, at c. $45^{\circ}$ to midrib; reticulum close; oil glands abundant; intramarginal vein distinct, within $1 \mathrm{~mm}$ of margin. Umbellasters axillary, 7 - to 11-flowered; peduncles terete, 2-13 $\mathrm{mm}$ long; pedicels terete, $1-5 \mathrm{~mm}$ long. Mature buds ovoid, sometimes elongate, 5-9 mm long, 3-5 mm diam.; calyptra rounded, obtuse or acute, 1-2 times as long as hypanthium. Stamens all fertile, outer whorls erect, inner whorls inflexed in bud; anthers subglobular, dorsifixed (attached very low on connective), subversatile, dehiscing by short angled slits. Fruits cup-shaped, verrucose, 3-locular, 4-7 mm long, 5-9 mm diam.; calyptra scar and stemonophore distinct, $0.25-0.5 \mathrm{~mm}$ wide, flat or slightly raised; disc $1-1.5 \mathrm{~mm}$ wide, flat or shallowly depressed; valves triangular, enclosed at bases, vertically raised, each with two dorsal lobes formed from outgrowths from the disc, tips often exserted; style sometimes persistent, remaining attached to one valve in open fruits. Seeds flattened-ovoid, dull, dark brown, very shallowly regularly pitted, c. $1 \mathrm{~mm}$ long; hilum ventral; chaff paler, smaller, linear or blocky.

The closest affinity of E. mannensis is with E. jutsonii Maiden, and not with the E. foecunda group as supposed by Boomsma in the protologue. E. jutsonii is distinguished by the linear adult and juvenile leaves.

Two groups of populations are recognised but as subspecies only, despite the lack of intergrades, since the differences are slight.

1 Adult leaves always glossy, largest leaves usually more than $12 \mathrm{~mm}$ wide 19a. subsp. mannensis

$1^{*}$ Adult leaves dull on new growth, largest leaves less than $12 \mathrm{~mm}$ wide 19b. subsp. vespertina

\section{9a. Eucalyptus mannensis Boomsma subsp. mannensis}

Adult leaves lanceolate, glossy, 6-15 cm long, 11-19 mm wide. Peduncles terete, 5-13 $\mathrm{mm}$ long. Mature buds 5-9 mm long, 3-4 mm diam. Fruits 4-7 mm long, 5-9 mm diam.

DisTRIBUTION: A taxon of the semidesert country, from the western and south-western edges of the Great Victoria Desert (Wiluna to north of Zanthus) east to north-western South Australia and south-western Northern Territory, to south of Alice Springs. Figure 21.

ECOLOGY: Widespread but sporadic on deep sand on red aeolian desert dunes.

CONSERvation Status: Not considered to be at risk. 
SElected SPECIMENS (from 40 examined): Western Australia (W to E): 29 miles [46 km] S of Wiluna on Sandstone road, Speck 1452, 16 Sep 1958 (CANB, NSW); $4.4 \mathrm{~km} \mathrm{~N}$ of Mulga Rock on Lake Minigwal track, Hill 2670 \& Johnson, 29 Nov 1986 (NSW, PERTH); c. 26 km SE of Giles Meteorological Station, Lazarides 8322, 9 May 1977 (CANB, NSW). South Australia: Mann Range, 39 miles [62 km] NE of Mt Davies camp, Dunlop 2017, 1 Nov 1970 (DNA, NSW). NORTHERN TERRITORY (W to E): 7 miles [11 km] N of Lake Amadeus, Chippendale NT 6360, 28 June 1959 (DNA, NSW); $28.6 \mathrm{~km}$ E of Curtin Springs, Hill 856, Johnson \& Benson, 10 July 1984 (NSW); 50 miles [80 km] $\mathrm{S}$ of Tempe Downs, Forde 186, 16 June 1956 (DNA, NSW); $116 \mathrm{~km} \mathrm{~N}$ of Kulgera, Brooker 9438, 30 Aug 1986 (CANB, NSW); Deep Well road, 34 miles [54 km] S of Alice Springs, Nelson 1855, 19 Mar 1969 (DNA, NSW).

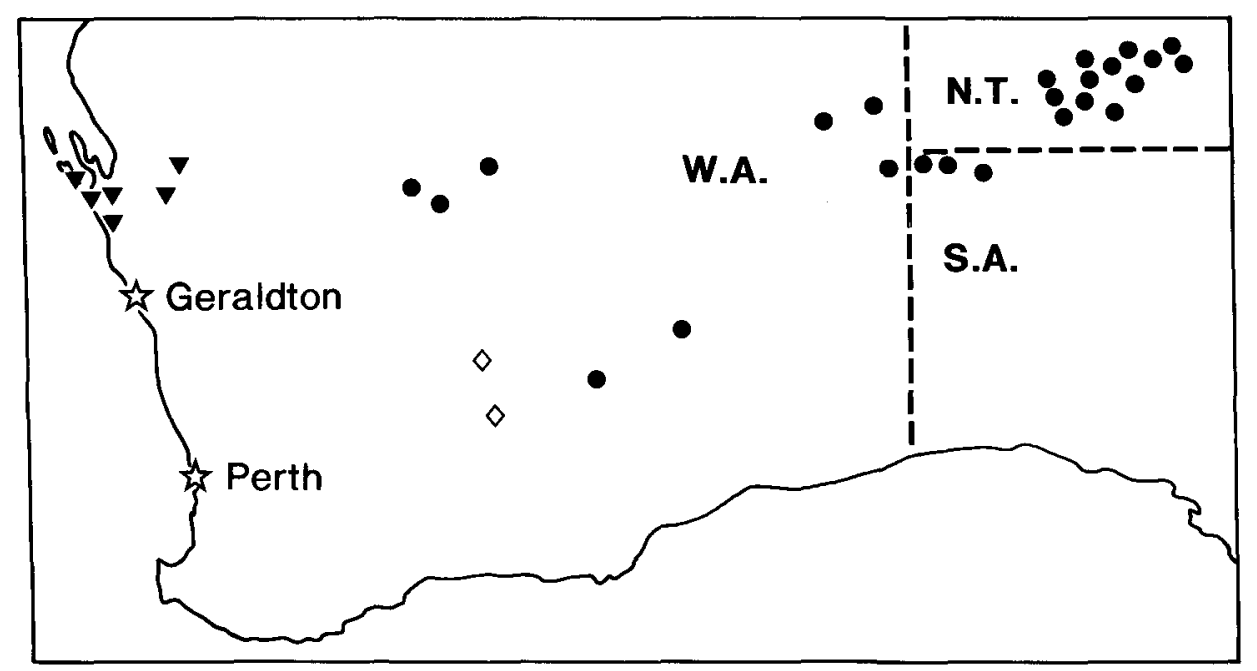

Figure 21. Distribution of E. mannensis subsp. mannensis $(\bullet)$, subsp. vespertina $(\boldsymbol{\nabla})$ and E. jutsonii $(\diamond)$.

19b. Eucalyptus mannensis Boomsma subsp. vespertina L. Johnson $\&$ K. Hill, subsp. nov.

Ab subspecie typica foliis adultis non nitentibus eis maximis plerumque angustioribus differt.

TyPe: Western Australia: $12 \mathrm{~km}$ W of road from 'Coburn' to 'Hamelin', D.F. Blaxell W75/101 \& M.I.H. Brooker, 8 Oct 1975 (holo NSW; iso CANB, PERTH).

Adult leaves narrow-lanceolate to lanceolate, dull, 7-12 cm long, 8-12 mm wide. Peduncles terete, 2-8 mm long. Fruits 5-6 mm long, 6-8 mm diam. Figure 22.

Distribution: Known only from the Shark Bay area. Figure 21.

Ecologr: A locally common mallee in red sandhill country.

Subsp. vespertina differs from subsp. mannensis in the duller and narrower adult leaves.

Subsp. 'western' of Brooker \& Kleinig (1990).

Conservation status: Not considered to be at risk.

The epithet is from the Latin vespertinus, belonging to the evening or western, in allusion to the subspecies' more westerly distribution.

Selected specimens (from 15 examined): Western Australia (W to E): 5 miles [8 km] from Shark Bay road towards Tamala, Brooker 2394, 10 Jan 1970 (PERTH, NSW); $6 \mathrm{~km} \mathrm{~N}$ of Wannoo, Blaxell W75/96 \& Brooker, 8 Oct 1975 (NSW, CANB, PERTH); $65 \mathrm{~km} \mathrm{~S}$ of Wannoo, Beadle 170, 2 Oct 1970 (UNE, NSW). 


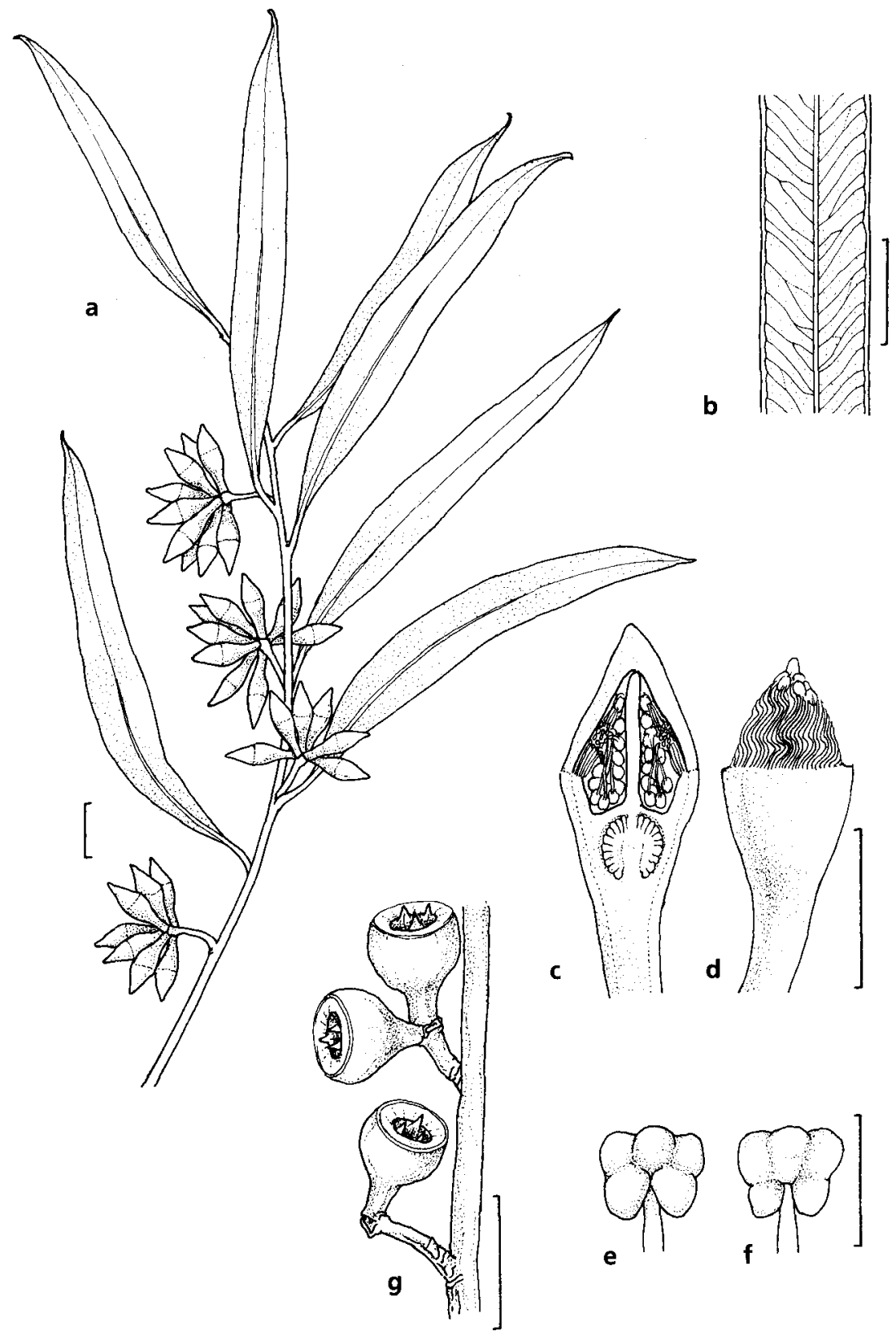

Figure 22. E. mannensis subsp. vespertina. $\mathbf{a}$, adult leaves and buds; $\mathbf{b}$, part of adult leaf showing venation; $\mathbf{c}$, section of bud; $d$, bud with calyptra removed, showing filament flexure; $\mathbf{e}, \mathbf{f}$, anther; $g$, fruits (all from Blaxell W75/101). Scale bar: $a, b, g=1 \mathrm{~cm} ; \mathrm{c}, \mathrm{d}=5 \mathrm{~mm} ; \mathrm{e}, \mathrm{f}=0.5 \mathrm{~mm}$. 


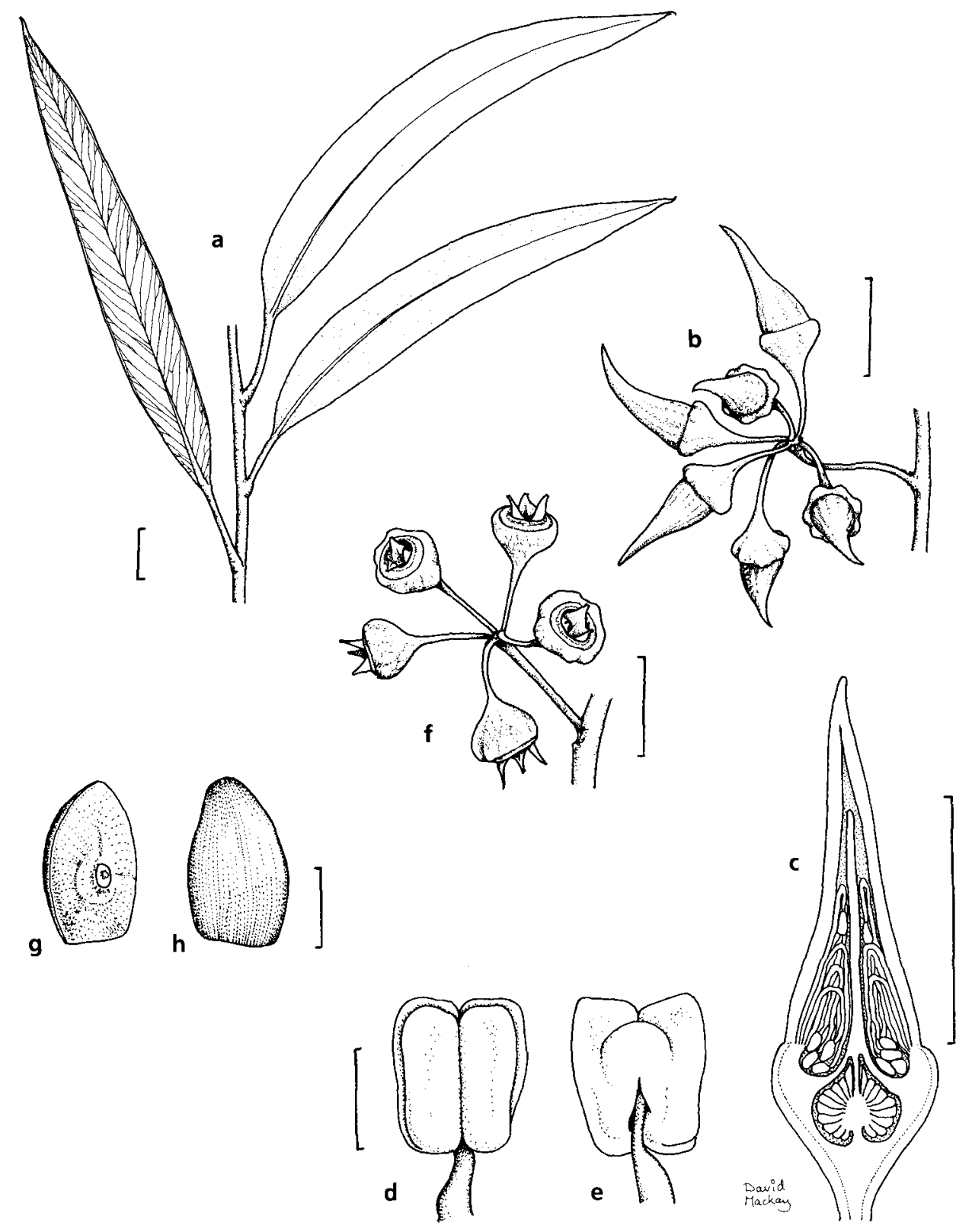

Figure 23. E. argyphea. $\mathbf{a}$, adult leaves; $\mathbf{b}$, buds; $\mathbf{c}$, section of bud; $\mathbf{d}, \mathbf{e}$, anther; $\mathbf{f}$, fruits; $\mathbf{g}, \mathbf{h}$, seed (all from Hill 659 et al.). Scale bar: a, b, c, $f=1 \mathrm{~cm} ; \mathrm{g}, \mathrm{h}=1 \mathrm{~mm} ; \mathrm{d}, \mathrm{e}=0.5 \mathrm{~mm}$. 


\section{Series Falcatae}

Species 20 to 26 are placed in series Falcatae, defined by the combination: pith glands absent; filaments inflexed or irregularly flexed; anthers oblong to ovoid, basifixed, versatile, dehiscing by broad, angled slits; seeds shallowly reticulately pitted, longitudinally grooved, dorsiventrally compressed.

\section{Eucalyptus argyphea L. Johnson $\mathcal{E} K$. Hill, sp. nov.}

Affinis E. ornatae sed alabastris fructibusque minoribus et minus costatim sculptis distinguitur. Inter species affinitatis $E$. falcatae combinatione sequenti characterum distinguitur: habitus arborescens (forma 'mallet'); cortex argenteo-albus; alabastra parva non vel vix sculpta; fructus parvi non valde sculpti, nitidi. Pedunculi pedicellique longi et graciles sunt.

TYPE: Western Australia: $12 \mathrm{~km} \mathrm{~W}$ of Harrismith on road to Wickepin $\left(32^{\circ} 55^{\prime} \mathrm{S}\right.$, $117^{\circ} 44^{\prime}$ E), K.D. Hill 659, L.A.S. Johnson, D.F. Blaxell, M.I.H. Brooker, S.D. Hopper, 8 Nov 1983 (holo NSW; iso CANB, PERTH).

\section{[Eucalyptus sp. J of Brooker \& Kleinig (1990)]}

Tree (mallet) to $15 \mathrm{~m}$, trunk straight to c. $5 \mathrm{~m}$. Bark smooth, shining pale silver-grey or white. Juvenile leaves opposite for many nodes, elliptic, acute or apiculate, to $4 \mathrm{~cm}$ long, $25 \mathrm{~mm}$ wide, petioles to $6 \mathrm{~mm}$ long. Adult leaves disjunct, lanceolate, usually falcate, acute or acuminate, \pm glossy, $5-10 \mathrm{~cm}$ long, 11-16 mm wide; petioles 10-16 $\mathrm{mm}$ long; lateral veins at $30-40^{\circ}$ to midrib, \pm closely-spaced, densely reticulate between; intramarginal vein distinct, $0.5-1.0 \mathrm{~mm}$ from margin. Umbellasters axillary, 7-flowered; peduncles terete, 9-13 mm long, slender; pedicels terete, 5-8 mm long, slender. Mature buds broad-conical, apically narrow-conical, 16-21 mm long, 5-7 mm diam.; calyptra narrow-conical, narrower than hypanthium, 2.5-3.5 times longer than hypanthium. Fruits globular, sometimes ribbed, 3-locular, apically constricted, 6-8 mm long, 5-7 $\mathrm{mm}$ diam.; calyptra scar flat, continuous with hypanthium, c. $0.5 \mathrm{~mm}$ wide; stemonophore distinct, flat, c. $1 \mathrm{~mm}$ wide; disc flat, c. $1 \mathrm{~mm}$ wide, separated from stemonophore by a groove, enclosing valve bases and sometimes breaking apart on dehiscence; style persistent, splitting into 3 on dehiscence and giving valves an attenuate appearance; valves and style remnants vertically exserted. Seeds glossy dark grey, elliptic, shallowly reticulate, 1.5-2.0 mm long; chaff smaller, reddish brown, angular. Figure 23.

Nearest to E. ornata Crisp, from which it differs in the generally smaller and less ribbed buds and fruits. Distinguished within the E. falcata Turcz. group by the tree (mallet) habit, the silver-white bark, the small, almost smooth buds (16-21 mm long, 5-7 mm diam.), and the small, often smooth, glossy fruits (6-8 $\mathrm{mm} \mathrm{long,} \mathrm{5-6} \mathrm{mm}$ diam.). Peduncles and pedicels are relatively long (9-13 and 5-8 $\mathrm{mm}$ respectively) and slender.

DistRiBution: Restricted to the southern Wheat Belt, from Harrismith to south of Lake King (Avon and Roe Districts). Figure 24.

ECOLOGY: A localised species in mallet woodlands on fairly level, pale sandy loams, but often on slight residual lateritic rises, with E. gardneri Maiden and E. longicornis (F. Muell.) F. Muell. ex Maiden. Once used for tanbark but now extensively cleared for wheatlands.

CONSERVATION STATUS: 3R. The range of this species lies almost wholly within agricultural country that has been extensively and indiscriminately cleared.

Intergrades are recorded with $E$. ornata. 
The specific epithet is from the Greek argypheos, silvery white, in reference to the striking and distinctive silvery bark of the trunk. The stress is on the second syllable, in English contexts pronounced 'jif'.

Selected specimens (from 16 examined): Western Australia (W to E): $13.3 \mathrm{~km} \mathrm{~S}$ of BrooktonCorrigin road on Dudinin road, Hill 2990, 31 Aug 1988 (NSW); $8.3 \mathrm{~km} \mathrm{~N}$ of Nyabing on Kukerin North Road, Brooker 9143, 9 Dec 1985 (CANB, NSW, PERTH); $6.7 \mathrm{~km}$ E of Needilup North Road on Ryans Road, Hill 3135, 7 Sep 1988 (NSW); $25.0 \mathrm{~km} \mathrm{~W}$ of Lake King towards Newdegate, Hill 2392, Johnson, Blaxell \& Brooker, 9 Nov 1986 (NSW, PERTH); $4.6 \mathrm{~km} \mathrm{~W}$ of Hatters Hill Road on Lake King-Norseman road, Brooker 8682, 8 Sep 1984 (CANB, NSW, PERTH).

Intergrades with E. ornata: $43.5 \mathrm{~km} \mathrm{~W}$ of Lake King-Hyden road on Holt Rock-Kulin road, Johnson 9188 \& B.G. Briggs, 1 Nov 1988 (NSW); Hatters Hill, Mollemans 2710, 26 May 1990 (NSW, PERTH, CANB).

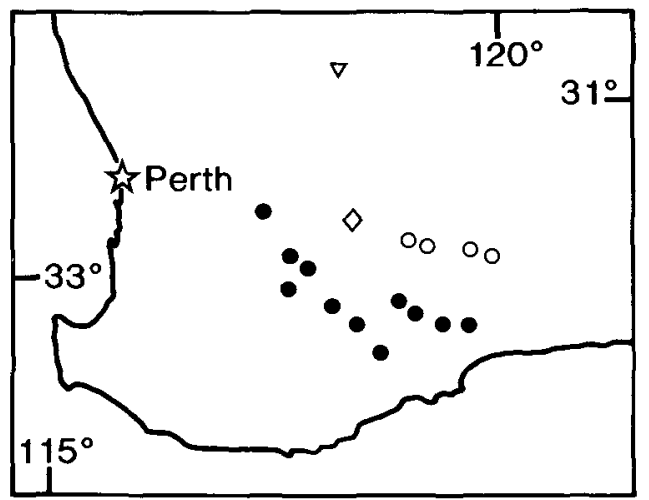

Figure 24. Distribution of E. argyphea $(\bullet)$, E. recta $(\nabla)$, E. ornata $(\diamond)$ and E. argyphea-E. ornata intergrades $(O)$.

21. Eucalyptus recta $L$. Johnson $\mathcal{E} K$. Hill, sp. nov.

Inter species affinitatis $E$. falcatae combinatione sequenti characterum distinguitur: habitus arborescens (forma 'mallet'); cortex argenteus vel albus; alabastra magna, sculpti in costas latas et non profundas; calyptra longa, acuta; fructus magna; pedunculi pedicellique longi.

TYPE: WESTERN AUSTRALIA: corner of Cadoux-Koorda road and Johnson Road, K.D. Hill 2504, L.A.S. Johnson \& D.F. Blaxell, 16 Nov 1986 (holo NSW; iso CANB, CBG, MEL, PERTH)

Tree (mallet) to $15 \mathrm{~m}$, trunk straight to c. $5 \mathrm{~m}$. Bark smooth, shining pale silver-grey or white. Juvenile leaves opposite for many nodes, elliptic, acute or apiculate, to $4 \mathrm{~cm}$ long, $25 \mathrm{~mm}$ wide, petioles to $6 \mathrm{~mm}$ long. Adult leaves disjunct, lanceolate, usually falcate, acute or acuminate, \pm glossy, 5-10 cm long, 11-16 mm wide; petioles 10-16 $\mathrm{mm}$ long; lateral veins at $30-40^{\circ}$ to midrib, \pm closely-spaced, densely reticulate between; intramarginal vein distinct, $0.5-1.0 \mathrm{~mm}$ from margin. Umbellasters axillary, 7-flowered; peduncles terete, 15-25 mm long, slender; pedicels terete, 9-18 $\mathrm{mm}$ long, slender. Mature buds broad-conical, apically narrow-conical, 22-25 mm long, 8-9 mm diam.; calyptra narrow-conical, narrower than hypanthium, 2.5-3.5 times longer than hypanthium. Fruits depressed-globular, distinctly ribbed, 3-locular, apically con- 
stricted, 8-9 mm long, 10-12 mm diam.; calyptra scar flat, continuous with hypanthium, c. $0.5 \mathrm{~mm}$ wide; stemonophore distinct, flat, c. $1 \mathrm{~mm}$ wide; disc flat, 1-2 $\mathrm{mm}$ wide, separated from stemonophore by a groove, enclosing valve bases and sometimes breaking apart on dehiscence; style persistent, splitting into 3 on dehiscence and giving valves an attenuate appearance; valves and style remnants vertically exserted. Seeds glossy dark grey, elliptic, shallowly reticulate, $1.5-2.0 \mathrm{~mm}$ long; chaff smaller, reddish brown, angular. Figure 25.

Nearest to E. ornata Crisp, from which it differs in the larger buds (buds $14-20 \mathrm{~mm}$ long in E. ornata). Distinguished in the E. falcata group by the tree habit, the white bark, the large buds (22-25 $\mathrm{mm}$ long, $8-9 \mathrm{~mm}$ diam.) which are broadly shallowly ribbed, the long, acute calyptra, the large fruits (8-9 $\mathrm{mm}$ long, 10-12 $\mathrm{mm}$ diam.). Pedicels and peduncles are relatively long (15-25 and 9-18 $\mathrm{mm}$ respectively).

DistRibution: Known from a small area near Cadoux (Avon District), well separated from the occurrence of E. ornata. Figure 24 .

Ecology: Locally frequent but very restricted, in mallet woodlands with $E$. gardneri Maiden, slightly above the surrounding country, as in the cases of E. argyphea and $E$. ornata.

CONSERVATION STATUS: $2 \mathrm{~V}$. Known only from a restricted area that lies wholly within agricultural country and has been extensively cleared.

The epithet is from Latin rectus, straight, referring to the straight trunks.

SeleCtEd SPECIMENS (from 5 examined): Western Australia (N to S): c. 3 miles [5 km] E of Cadoux, B. Smith 644, 13 Feb 1986 (MEL, CANB, HO, NSW, PERTH); Brooker 9381, 2 July 1986 (CANB, NSW, PERTH); near Manmanning, B. \& M. Smith, 13 Feb 1985 (CBG 8600356, NSW).

\section{Eucalyptus balanopelex L. Johnson $\mathcal{E}$ K. Hill, sp. nov.}

Affinis E. semiglobosae sed characteribus sequentibus distinguitur: folia adulta minora angustioraque, pedicelli longiores et calyptra major longiorque.

TYPe: Western Australia: $0.5 \mathrm{~km}$ from Fisheries road on Coolinup Road, K.D. Hill 2285 $\mathcal{E}$ L.A.S. Johnson, 6 Nov 1986 (holo NSW; iso CANB, CBG, MEL, PERTH).

Mallee to $4 \mathrm{~m}$. Bark smooth throughout, grey or light brown. Adult leaves disjunct, similifacial, broad-lanceolate, acute or acuminate, 5-12 cm long, 7-28 mm wide; petioles $10-23 \mathrm{~mm}$ long, flattened; lateral veins moderately spaced, regular, at $30-45^{\circ}$ to midrib; reticulum regular; oil glands medium size, sparse; intramarginal vein continuous, distinct, $0.5-1.0 \mathrm{~mm}$ from margin. Inflorescences simple, axillary; umbellasters 7-flowered; peduncles terete, 10-20 mm long; pedicels terete, 5-11 mm long. Mature buds ovoid, smooth or shallowly ribbed, c. $16 \mathrm{~mm}$ long, c. $9 \mathrm{~mm}$ diam.; calyptra conical, convex, obtuse or rounded, c. 1.5 times longer than hypanthium. Stamens all fertile; filaments regularly inflexed; anthers shortly oblong, dorsifixed, versatile, dehiscing through short parallel slits. Fruit globular-truncate, usually somewhat ribbed, 3-4-locular, 8-10 mm long, 10-12 mm diam.; calyptra scar flat, 0.3-1.0 mm wide; inner growth zone scar flat, $0.5-1.0 \mathrm{~mm}$ wide; stemonophore elevated $0.5-1.0 \mathrm{~mm}$ above scar, flat, $0.5-1.0 \mathrm{~mm}$ wide; disc \pm vertically depressed, c. 1-2 $\mathrm{mm}$ wide; valves narrowly triangular, long apiculate with persistent style remnants, basally deeply enclosed, apically vertically exserted, to $5 \mathrm{~mm}$ long. Figure 26.

E. balanopelex differs from E. semiglobosa (Brooker) L. Johnson \& K. Hill in the larger buds with a larger and longer calyptra, the longer pedicels and the smaller and narrower adult leaves. It occurs in a swampy sandplain habitat in contrast to the granite shelf habitat of E. semiglobosa. 


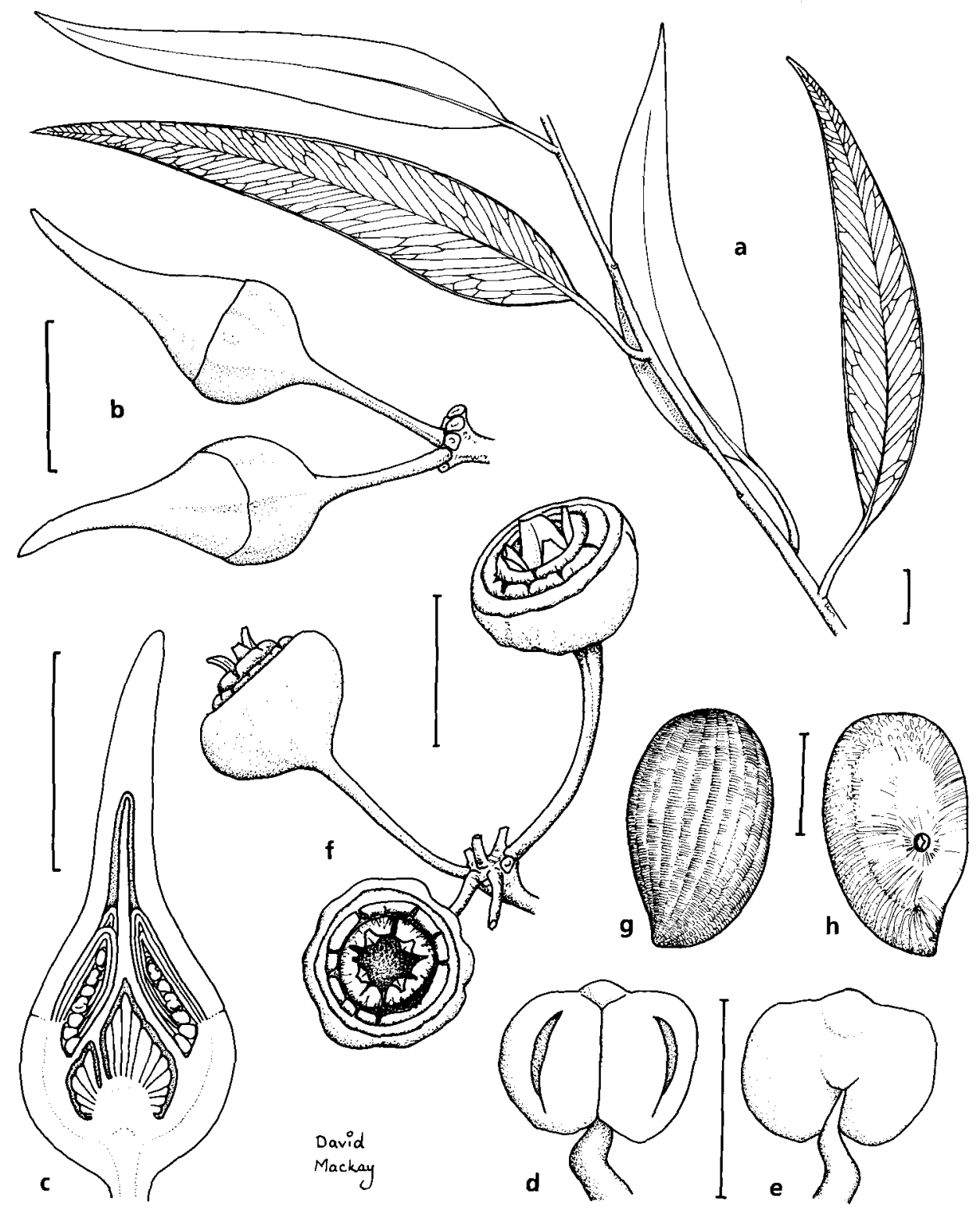

Figure 25. E. recta. a, adult leaves; $\mathbf{b}$, buds; $\mathbf{c}$, section of bud; $\mathbf{d}, \mathbf{e}$, anther; $\mathbf{f}$, fruits; $\mathbf{g}, \mathbf{h}$, seed (a - e from Smith 644, $\mathbf{f}-\mathbf{h}$ from Brooker 9381). Scale bar: a, b, c, f = 1 cm; d, e, g, h=1 mm. 
DistRiBution: Known only from two populations in the subcoastal area east of Esperance (Eyre District). Figure 27.

ECOLOGY: This is an uncommon species, occurring in small stands in mallee heathland on swampy white or grey sandplain.

CONSERVATION STATUS: $2 \mathrm{~V}$. Of restricted occurrence in an area that is suffering active agricultural development.

The epithet is from the Greek balanos, an acorn, and pelex, a helmet, referring to the shape of the calyptra. The stress is on the penultimate syllable, because of the long ' $\mathrm{e}$ ' (eta) in the Greek.

SeleCted SPECIMENS (from 5 examined): Western Australia: $14 \mathrm{~km}$ from Fisheries Road on Merivale Road, L. Johnson 9067 \& M. Johnson, 14 May 1988 (NSW, CANB, MEL, PERTH); 30.1 miles [48 $\mathrm{kml}$ E of Esperance, Chippendale 400, 25 Mar 1968 (CANB, NSW, PERTH).

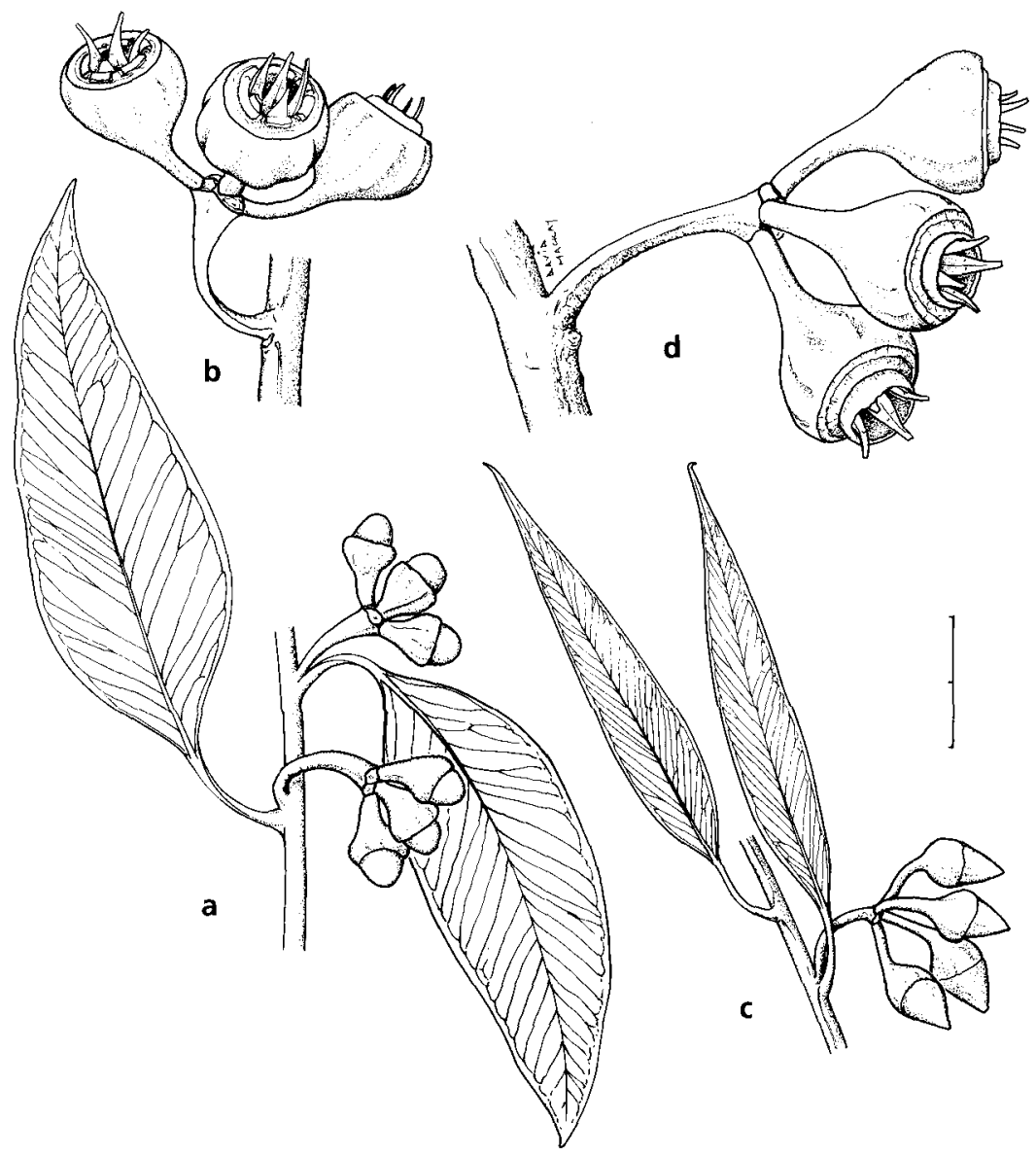

Figure 26. E. semiglobosa. a, adult leaves and buds; b, fruits (all from Brooker 3613). E. balanopelex. c, adult leaves and buds; d, fruits (all from Hill $2285 \&$ Johnson). Scale bar $=1 \mathrm{~cm}$. 


\section{Eucalyptus semiglobosa (Brooker) L. Johnson \& K. Hill, stat. nov.}

BAsIONYM: Eucalyptus goniantha Turcz. subsp. semiglobosa Brooker, Nuytsia 2: 110 (1976).

TYPE CitATron: 'Type: Between Mt Le Grand and Frenchmans Peak, Western Australia

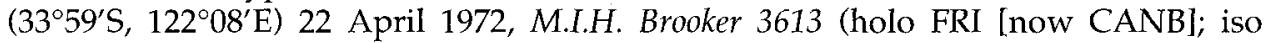
PERTH, NSW, K, AD, MEL, BRI).'

Mallee to $4 \mathrm{~m}$. Bark smooth throughout, grey or light brown. Adult leaves disjunct, similifacial, broad-lanceolate, acute or acuminate, $6-12 \mathrm{~cm}$ long, $18-38 \mathrm{~mm}$ wide; petioles $12-32 \mathrm{~mm}$ long, \pm quadrangular; lateral veins moderately spaced, regular, at $30-45^{\circ}$ to midrib; reticulum regular; oil glands medium size, sparse; intramarginal vein continuous, distinct, $0.5-1.0 \mathrm{~mm}$ from margin. Inflorescences simple, axillary; umbellasters 7-flowered; peduncles terete, 9-21 mm long; pedicels terete, 2-8 mm long. Mature buds ovoid, smooth or shallowly broadly ribbed, 9-11 $\mathrm{mm}$ long, 7-9 $\mathrm{mm}$ diam.; calyptra hemispherical or oblong, rounded, about as long or slightly longer than hypanthium. Stamens all fertile; filaments regularly inflexed; anthers shortly oblong, dorsifixed, versatile, dehiscing through short parallel slits. Fruit globulartruncate, usually somewhat ribbed, 3-4-locular, 8-10 mm long, 10-14 mm diam.; calyptra scar flat, $0.3-1.0 \mathrm{~mm}$ wide; inner growth zone scar flat, $0.5-1.0 \mathrm{~mm}$ wide; stemonophore elevated $0.5-1.0 \mathrm{~mm}$ above scar, flat, $0.5-1.0 \mathrm{~mm}$ wide; disc \pm vertically depressed, c. 1-2 mm wide; valves narrowly triangular, long apiculate with persistent style remnants, basally deeply enclosed, apically vertically exserted, to $5 \mathrm{~mm}$ long. Figure 26.

This taxon is distinguished from E. goniantha Turcz. by the elongate pedicels and peduncles and the relatively short, broad calyptra. Recent discovery of E. goniantha subsp. notactites (see below) within a few hundred metres of the type locality of E. semiglobosa indicates that the two are almost sympatric and show little interbreeding. Subspecific status is thus not appropriate. Its sister species is probably E. balanopelex, and the two together are then closest to E. falcata, with a more distant relationship with E. goniantha.

Distribution: Scattered and very sporadic, from Cape Le Grand to Cape Arid (Eyre District). Figure 27.

ECOLOGY: Known from a few stands only, on shallow sandy soil on subcoastal granite domes east of Esperance.

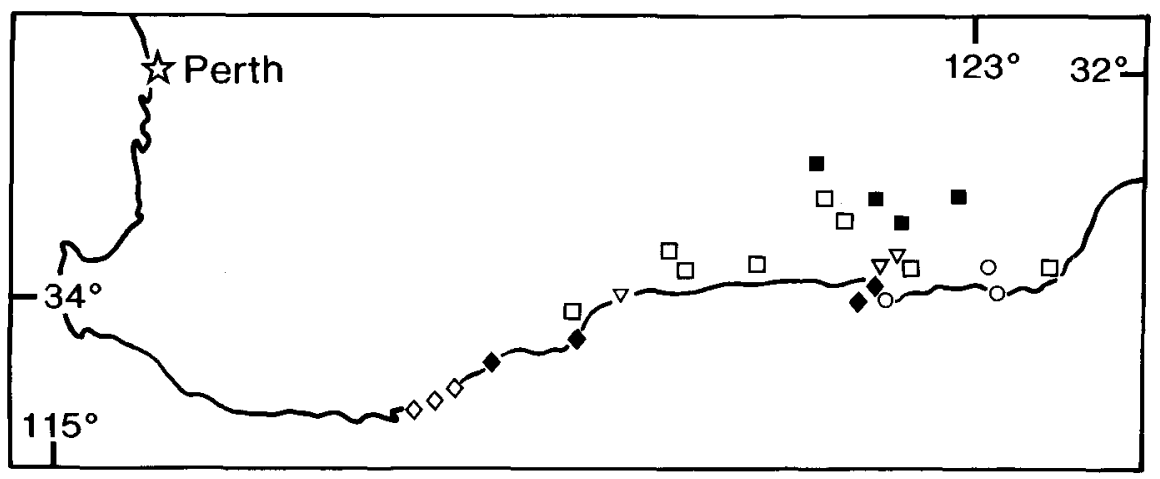

Figure 27. Distribution of E. goniantha subsp. goniantha $(\diamond)$, subsp. notactites $(\bullet)$, E. kessellii subsp. kessellii $(\square)$, subsp. eugnosta $(\square)$, E. balanopelex $(\nabla)$ and E. semiglobosa $(\bigcirc)$. 
Conservation status: 2RC. Stands of this species occur in Cape Le Grand and Cape Arid National Parks.

Selected SPECIMENS (from 8 examined): Western Australia: Whalebone to Quoin Head, Brooker 10152, 13 Dec 1988 (CANB, NSW, PERTH); Boyatup Hill, Pullen 10085, 18 Dec 1974 (CANB, NSW); SE side and base of Mt Arid, Hardie 13, 23 Nov 1985 (NSW); 300 metres E of old Hill Springs homestead, SE side of Mt Arid, Hill 3161, 8 Sep 1988 (NSW, AD, CANB, MEL, PERTH).

24. Eucalyptus goniantha Turcz., Bull. Soc. Imp. Nat. Moscou 20(1): 163 (1847).

TYPe CITATION: 'Nova Hollandia, Drum, n. 71.'

Type: Western Australia: King George Sound, Swan River Colony, J. Drummond, 3rd collection no. 71, 1845 (holo LE; iso BM, CGE, E, FI, G, K, W).

$\equiv$ E. incrassata Labill. var. goniantha Maiden, Crit. Revis. Eucalyptus 1: 103 (1904).

The name E. goniantha was misapplied by Bentham (1867) to the taxon shown to be E. kessellii by critical examination of the types (see below). This misapplication was followed by subsequent authors. Both Maiden and Blakely recognised the type form of E. kessellii as a distinct taxon (see below), but persisted with the misapplication for the more widespread and less distinctive form discussed below. Brooker \& Kleinig (1990) correctly apply the names $E$. goniantha and E. kessellii, although they include E. semiglobosa (above) in the former, and illustrate fruits of E. kessellii as E. goniatha.

Mallee to $6 \mathrm{~m}$, rarely a tree. Bark smooth, grey to brown or orange, shedding in patchily adherent scales, especially on lower trunk. Branchlets winged, glaucous. Juvenile leaves disjunct, petiolate, ovate to orbicular, to $13 \mathrm{~cm}$ long, $8 \mathrm{~cm}$ wide. Adult leaves disjunct, broad-lanceolate to ovate, acute to acuminate, dull, 6-15 cm long, 10$50 \mathrm{~mm}$ wide; petioles angular, 9-25 mm long, angles decurrent; lateral veins at $30-45^{\circ}$ to midrib, \pm closely spaced, regular, densely reticulate between; intramarginal vein distinct, 1-2 $\mathrm{mm}$ from margin. Umbellasters axillary, 7-11-flowered; peduncles strongly winged, 7-16 $\mathrm{mm}$ long, to $7 \mathrm{~mm}$ wide apically; pedicels $0-5 \mathrm{~mm}$ long, to 3 $\mathrm{mm}$ wide. Mature buds elongate-ovoid, apically constricted, hypanthium \pm 2 -winged, 8-17 mm long, 5-7 mm diam.; calyptra conical, obtuse, with a distinct median constriction, 1-1.5 times longer than hypanthium. Stamens all fertile; filaments regularly inflexed in bud, kinked at point of flexure; anthers shortly oblong, dorsifixed, versatile; cells divergent, dehiscing by short slits. Fruits globular to hemispherical, apically constricted, 3-4-locular, 6-9 mm long, 6-11 mm diam.; calyptra scar distinct, recessed, flat, c. $0.5 \mathrm{~mm}$ wide; disc $1.5-2 \mathrm{~mm}$ wide, depressed at c. $45^{\circ}$; valves deeply enclosed basally, vertically exserted, long-acuminate with remains of persistent style fused to each valve. Seeds semiglossy, dark grey to black, elliptic, shallowly reticulate, 1.5-2.0 mm long; hilum ventral; chaff smaller, angular, glossy red-brown.

Distinguished within the series by the combination: bark smooth; juvenile leaves broad; peduncles and pedicels short, thick; fruits rounded, apically contracted.

Two geographic subspecies are recognised chiefly on differences in pedicel length.

1 Pedicels more than $2 \mathrm{~mm}$ long 24a. subsp. goniantha

$1^{*}$ Pedicels less than $1 \mathrm{~mm}$ long or absent

24b. subsp. notactites

\section{4a. Eucalyptus goniantha Turcz. subsp. goniantha}

Branchlets winged, not glaucous. Adult leaves disjunct, lanceolate to broad-lanceolate, acute to acuminate, dull, 8-11 cm long, 10-20 mm wide; petioles 9-25 mm long.

7-11-flowered; peduncles $7-10 \mathrm{~mm}$ long, to $0.7 \mathrm{~mm}$ wide apically. Pedicels more than 
$2 \mathrm{~mm}$ long. Buds 8-14 $\mathrm{mm}$ long, 4-6 mm diam. Fruits pedicellate, hemispherical, 6-8 $\mathrm{mm}$ long, 6-9 mm diam.

Distribution: Known only from a few headlands and subcoastal hills in the Two Peoples Bay area (Menzies District). Figure 27.

ECOLOGY: Locally frequent but very restricted in distribution, in dense coastal shrub heath on shallow sandy soils.

Isolated occurrences of intergrading forms with E. falcata Turcz. (sens. lat.) are known. CONSERVATION Status: 2RC.

Selected sPecimens (from 5 examined): Western Australia: walking track on Flinders Peninsula, Brooker 9993, 20 July 1988 (CANB, NSW, PERTH); c. $3 \mathrm{~km}$ W of Manypeaks, Brooker 9822, 26 Nov 1987 (CANB, NSW, PERTH); West Ridge, Two Peoples Bay, Brooker 7191, 15 Nov 1981 (CANB, NSW, PERTH).

E. falcata sens. lat. - E. goniantha subsp. goniantha intergrade: $26 \mathrm{~km}$ E of Bakers Junction on road to Manypeaks, Brooker 8738, 29 Nov 1984 (CANB, NSW, PERTH).

24b. Eucalyptus goniantha Turcz. subsp. notactites L. Johnson $\mathcal{E}$ K. Hill, subsp. nov.

$\mathrm{Ab}$ subspecie typica ramulis novellis et pedunculis valde alatis; foliis longioribus crassioribusque et fructibus plus sessilibus differt.

TYPE: WeSTERn Australia: Mt Melville garbage tip, $16.5 \mathrm{~km}$ from highway, K.D. Hill 2429, L.A.S. Johnson, D.F. Blaxell E M.I.H. Brooker, 12 Nov 1986 (holo NSW; iso PERTH).

Branchlets winged, glaucous. Adult leaves disjunct, broad-lanceolate to ovate, acute to acuminate, dull, 6-15 cm long, 15-50 mm wide; petioles 9-25 $\mathrm{mm}$ long. Umbellasters 7-11-flowered; peduncles 9-16 $\mathrm{mm}$ long, to $0.7 \mathrm{~mm}$ wide apically. Mature buds sessile or on short pedicels (to $1 \mathrm{~mm}$ long), hypanthium \pm 2 -winged, 11-17 $\mathrm{mm}$ long, 5-7 $\mathrm{mm}$ diam. Fruits globular, sessile, \pm 2 -winged, $6-8 \mathrm{~mm}$ long, $8-10 \mathrm{~mm}$ diam. Figure 28.

Subsp. notactites differs from subsp. goniantha in the more sessile buds and fruits, the strongly winged young branchlets and peduncles, and the longer, thicker leaves.

It was referred to as E. goniantha subsp. 'sessile fruit', by Brooker \& Kleinig (1990).

Distribution: This taxon has a very scattered, sporadic distribution from Mt Melville in the Cape Riche area east to Cape Le Grand, with a large disjunction in the range. Figure 27.

ECOLOGY: Locally frequent on shallow sand on laterite or on white sand, known only from sites very near the sea.

CONSERVATION STATUS: 3RC.

The epithet is from the Greek notos, the south, and aktites, a watcher, from the subspecies' occurrence on the south-facing oceanic coast.

Selected specimens (from 10 examined): Western Australia ( $W$ to E): Konkoberup Hill (Mt Melville), Brooker 8945, 12 Apr 1985 (CANB, NSW, PERTH); Cape Riche, Diels 3504, 18 July 1901 (B, NSW); $5.5 \mathrm{~km}$ S of Borden-Bremer Bay road on Reef Beach Road, Brooker 8872, 2 Mar 1983 (CANB, NSW, PERTH); c. $2 \mathrm{~km} \mathrm{~W}$ of Hood Point, Brooker 9918, 9 Mar 1988 (CANB, NSW, PERTH); Cape Le Grand, Hill 3156, 8 Sep 1988 (NSW, CANB, PERTH); Sandy Hook Island near Esperance $\left(34^{\circ} 04^{\prime} \mathrm{S}, 122^{\circ} 20^{\prime} \mathrm{E}\right)$, Brooker 7492, 7493, 1 May 1982 (CANB, NSW, PERTH).

Intergrades between the subspecies: Cheyne Beach, $1 \mathrm{~km}$ along track to Mermaid Point, Brooker 7170,14 Nov 1981 (CANB, NSW, PERTH). 


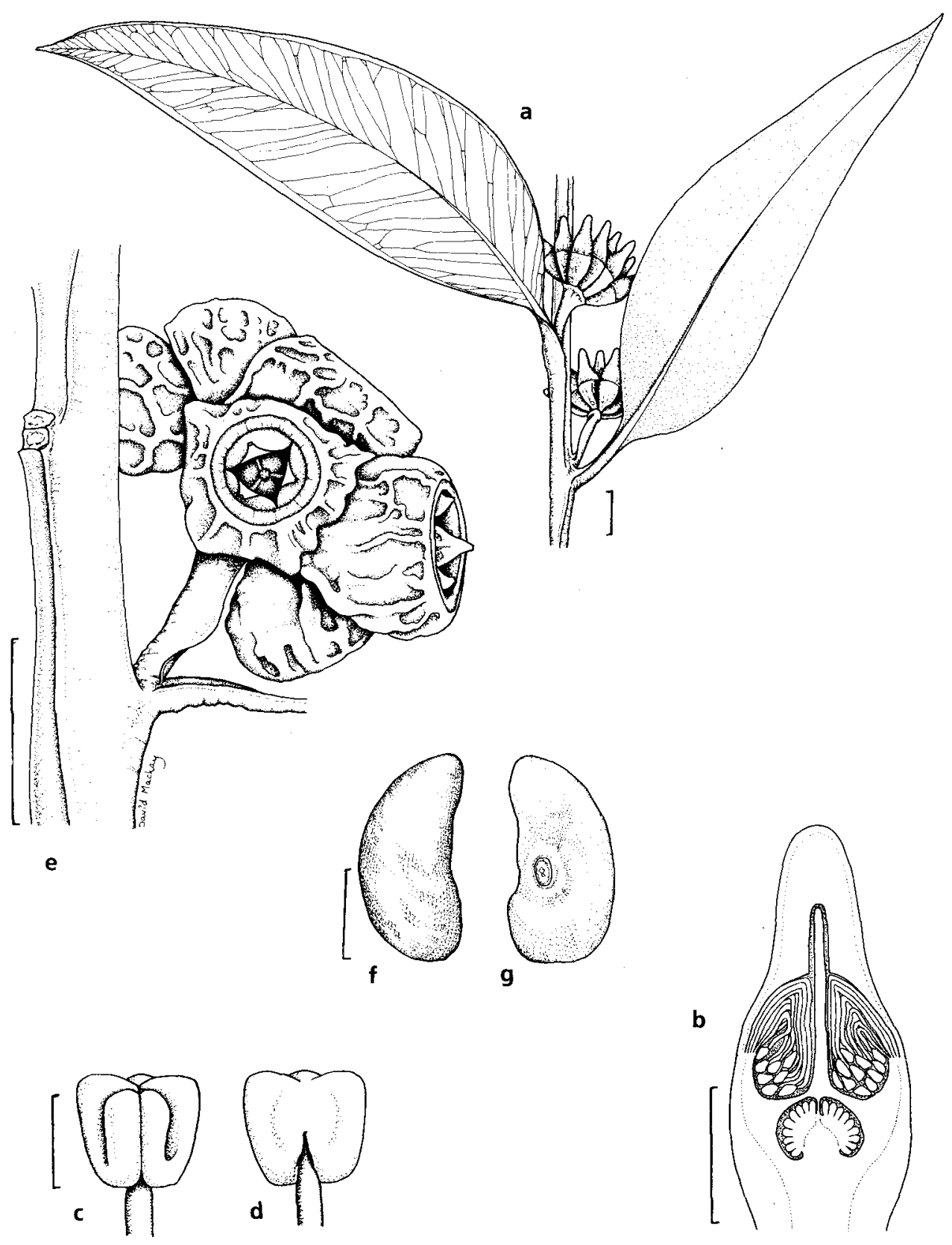

Figure 28. E. goniantha subsp. notactites. a, adult leaves and buds; $\mathbf{b}$, section of bud; $\mathbf{c}, \mathbf{d}$, anther; e, fruits; $\mathrm{f}, \mathrm{g}$, seed (a - d from Brooker 7492, e - $\mathrm{g}$ from Brooker 7493); Scale bar: $\mathrm{a}, \mathrm{f}=1 \mathrm{~cm}$; $\mathrm{b}=5 \mathrm{~mm} ; \mathrm{g}, \mathrm{h}=1 \mathrm{~mm} ; \mathrm{d}, \mathrm{e}=0.5 \mathrm{~mm}$. 
25. Eucalyptus kessellii Maiden \& Blakely, J. \& Proc. Roy. Soc. New South Wales 59: 187 (1925).

TYPE CitATION: 'Known only from Western Australia. Found in sandy loam in Mallee thickets at a place called Salmon Gums, 66 miles north of Esperance (W.P. Brown per C.A. Gardner, no. 944a; the type).'

TYPE: holo NSW; iso PERTH.

[E. goniantha auct. plur. non Turcz.: Bentham (1867); Maiden, Crit. Revis. Eucalyptus 2: 200 (1912); Blakely (1934); Gardner (1960); Chippendale (1973); Chippendale (1988); Brooker \& Kleinig (1990: 216, photograph of fruits). Both Maiden and Blakely recognised the type form of E. kessellii as a taxon distinct from the less coarse and more widely known form which they regarded incorrectly as E. goniantha, and which we separate as a subspecies of E. kessellii, below. Gardner (1960) included E. kessellii in E. goniantha, and was followed by Chippendale (1973, 1988).]

[E. corrugata auct. non Luehmann, Victorian Nat. 13: 168 (1897). The binomial E. corrugata was also published as a nomen nudum by Diels \& Pritzel (1905: 443), and that publication was then cited (as E. corrugata Luehmann ex Diels) as a synonym of E. goniantha (in the incorrect application of the latter name) in Index Kewensis. The Diels publication cites the same specimen as the type in Luehmann's earlier publication, a Sayer collection from near Southern Cross, which is a specimen of E. corrugata Luehmann, and collected at a great distance from the nearest occurrence of $E$. goniantha.]

Tree or mallee to $10 \mathrm{~m}$. Bark persistent for basal $0.5-3 \mathrm{~m}$, dark grey, coarsely fibrous, then smooth, grey, pink and pale brown. Juveniles leaves disjunct, ovate to orbicular, to $12 \mathrm{~cm}$ long, $8 \mathrm{~cm}$ wide, becoming broad-lanceolate. Adult leaves disjunct, lanceolate to broad-lanceolate, acute or acuminate, similifacial, 7-14 cm long, 22-34 mm wide; petioles $10-22 \mathrm{~mm}$ long; lateral veins regular, at $30-40^{\circ}$ to midrib; oil glands densely packed. Inflorescences simple, axillary; umbellasters 3-7-flowered; peduncles thick, angular or \pm flattened, 12-25 mm long; pedicels angular, 1-4 mm long. Buds broadly ovoid, almost smooth to prominently ribbed, 13-25 mm long, 10-15 mm diam.; calyptra conical, often beaked, smooth to ribbed. Stamens all fertile; filaments regularly inflexed; anthers ovoid, versatile, dorsifixed low on connective gland, dehiscing through lateral pores. Fruits obconical, almost smooth to prominently ribbed, 4-5-locular, 10-18 mm long, 12-18 mm diam.; calyptra scar raised at c. $45^{\circ}, 1.5-2 \mathrm{~mm}$ wide; stemonophore \pm raised, $0.5-1.0 \mathrm{~mm}$ wide, usually splitting due to greater differential growth in underlying hypanthium; disc flat, ultimately markedly incurved, 2-3 mm wide; valves narrowly triangular, long-apiculate with persistent style remnants, basally deeply enclosed, apically vertically exserted, to $7 \mathrm{~mm}$ long.

Two geographic subspecies are recognised on differences in fruit ornamentation.

1 Fruits distinctly ribbed, ribs more than $1 \mathrm{~mm}$ high 25a. subsp. kessellii

$1^{*}$ Fruits smooth or with ribs less than $1 \mathrm{~mm}$ high 25b. subsp. eugnosta

\section{5a. Eucalyptus kessellii Maiden \& Blakely subsp. kessellii}

Bark persistent on lower trunk. Buds and fruits prominently ribbed. Umbellasters sometimes 3-flowered. Figure 29.

Distribution: This subspecies occupies a zone to the north and north-east of Esperance, from around Salmon Gums to north-east of Mt Ney. Figure 27.

ECOLOGY: Locally frequent in tall mallee woodland on flat sites on pale sandy often somewhat calcareous clay-loams, often with woodland species such as E. creta 
L. Johnson \& K. Hill and E. oleosa F. Muell. ex Miq. (sens. lat.).

COnSERvation status: Not considered to be at risk.

SELECTED SPECIMENS (from 7 examined): Western Australia (W to E): $28 \mathrm{~km}$ NE of Mt Ridley on track, Blaxell 86/091, Johnson, Hill \& Brooker, 5 Nov 1986 (NSW); Mt Ney Road, Brooker 8928, 10 Apr 1985 (CANB, NSW, PERTH); 30 miles [50 km] NE of Mt Ney, Beard 6377, 17 Sep 1970 (PERTH, NSW).

25b. Eucalyptus kessellii Maiden \& Blakely subsp. eugnosta L. Johnson \& K. Hill, subsp. nov.

Ab subspecie typica umbellastris regulariter 7-floris et alabastris fructibusque minoribus et prominenter costatis differt.

TYPe: Western Australia: $15.2 \mathrm{~km}$ W of highway on Speddingup West Road, K.D. Hill 2397, L.A.S. Johnson, D.F. Blaxell E M.I.H. Brooker, 7 Nov 1986 (holo NSW; iso CANB, CBG, MEL, PERTH).
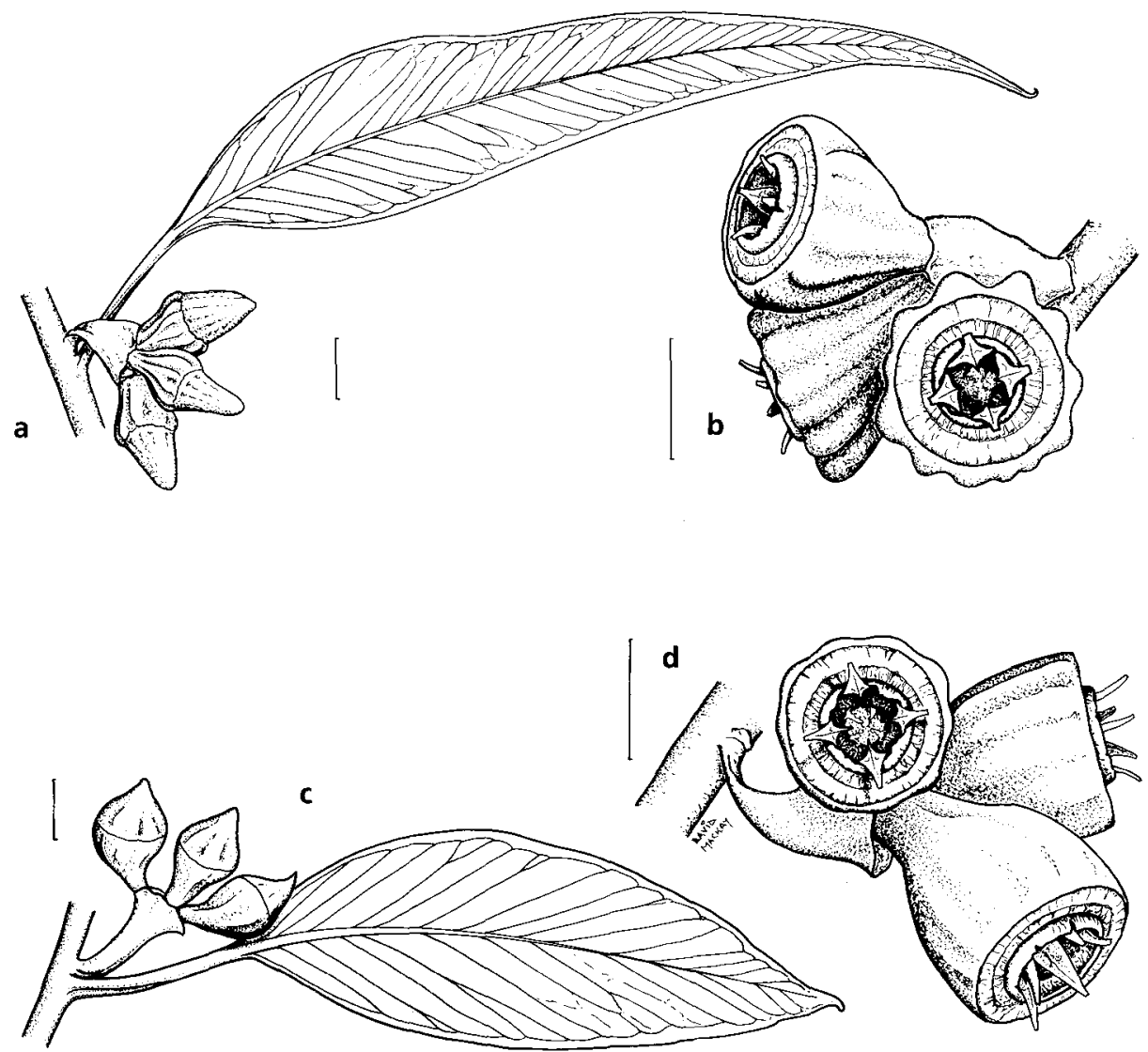

Figure 29. E. kessellii subsp. kessellii. a, adult leaves and buds; b, fruits (all from Brooker 8928). Subsp. eugnosta. c, adult leaves and buds; d, fruits (all from Hill 2297 et al.). Scale bar $=1 \mathrm{~cm}$. 
Bark smooth. Buds and fruits smooth to shallowly ribbed. Umbellasters 7-flowered. Figure 29.

Distinguished from subsp. kessellii by the smooth bark, the consistently 7-flowered umbellasters, and the smooth or less prominently ribbed buds and fruits.

Distribution: Subsp. eugnosta occurs to the south of subsp. kessellii, nearer the coast. It also ranges further in both easterly and westerly directions, from about the Hamersley River east almost to Israelite Bay (Eyre District). Figure 27.

ECOLOGY: Locally frequent in mixed mallee scrub on pale sandy soils, often over laterites. This taxon occurs in a more typical 'sand plain mallee' habitat and community than subsp. kessellii.

Hybrids are recorded with E. falcata Turcz. (sens. lat.).

Conservation status: Not considered to be at risk.

The epithet is from the Greek eugnostos, well-known or familiar, this being the betterknown race of $E$. kessellii, though not the one that includes the nomenclatural type.

Sel.ected specimens (from 13 examined): Western Australia ( $W$ to E): $3.5-4$ miles [5.5-6.5 km] N of Mt Bland, Fitzgerald River Nat. Park, Tindale 3854a, 30 Aug 1973 (NSW, PERTH); 8.8 miles [14 km] SE of Jerdacuttup River crossing on highway, Tindale 3814, 28 Aug 1973 (NSW, PERTH); $90 \mathrm{~km} \mathrm{~W}$ of Esperance on Ravensthorpe road, Blaxell 1687, 22 June 1978 (NSW, PERTH); 31.2 miles [50 km] E of Esperance, Chippendale 401, 25 Mar 1968 (CANB, NSW); c. $2.5 \mathrm{~km}$ from Israelite Bay track on Mt Ragged track, Brooker 8914, 8 Apr 1985 (CANB, NSW, PERTH).

Intergrades between the subspecies: Western Australia: 45.2 miles [72 km] W of Esperance, Chippendale 193, 15 Mar 1967 (CANB, NSW); 29.7 miles [47.5 km] E of Esperance, Brooker 2506, 15 Feb 1970 (PERTH, NSW).

E. falcata sens. lat. x E. kessellii subsp. eugnosta: Western Australia: $90 \mathrm{~km} \mathrm{~W}$ of Esperance on Ravensthorpe road, Blaxell 1691, 22 June 1978 (NSW, PERTH).

\section{Eucalyptus balladoniensis Brooker, Nuytsia 2(2): 103, Figure 1, 2 (1976).}

TYPE CITATION: ' $80 \mathrm{~km}$ by road south of Zanthus towards Balladonia, W.A. (31 ${ }^{\circ} 37^{\prime} \mathrm{S}$, 1235'ㄹ); M.I.H. Brooker 2471, 13.2.1970 (holo PERTH; iso FRI [now CANB], NSW).'

TYPE: The Holotype specimen (in PERTH) is from the Balladonia race (subspecies balladoniensis, with pedicellate fruit), although the citation refers to a locality where the Zanthus race (subsp. sedens, with sessile buds and fruits) is known to occur. All other specimens from the cited locality match the Zanthus race, including supposed duplicates of the Type (cited as distributed to FRI [now CANB] and NSW but actually held in PERTH). The actual Holotype bears no field collection tag, whereas the 'duplicates' bear 'Brooker 2471 ' tags. The protologue description and illustration are consistent with the Balladonia race, and Brooker (pers. comm.) states that specimens have apparently been mixed, and that the protologue was drawn up from the Balladonia material. The untagged specimen in PERTH is hence regarded as the Holotype. The cited locality and details do not correspond to this specimen, and are regarded as erroneous. The Holotype matches a later collection (Brooker 3653) from $20 \mathrm{~km} \mathrm{~W}$ of Balladonia on Highway 1, and this can be regarded as the type locality.

Mallee to $10 \mathrm{~m}$. Bark persistent for basal 0.5-3 m, then smooth, grey and pale brown. Juveniles leaves disjunct, linear, to $8 \mathrm{~cm}$ long, $5 \mathrm{~mm}$ wide, becoming lanceolate. Adult leaves disjunct, lanceolate, acute or acuminate, similifacial, 7-13 cm long, 12-25 mm wide; petioles $10-22 \mathrm{~mm}$ long; lateral veins regular, at $30-40^{\circ}$ to midrib; oil glands densely packed. Inflorescences simple, axillary; umbellasters 7-flowered; peduncles thick, angular or \pm flattened, 6-20 mm long; pedicels angular, 1-9 $\mathrm{mm}$ long. Buds ovoid, 
distinctly broadly beaked, 17-22 $\mathrm{mm}$ long, 8-11 mm diam.; calyptra broadly rostrate. Stamens all fertile; filaments regularly inflexed; anthers ovoid, versatile, dorsifixed low on connective gland, dehiscing through lateral pores. Fruits obconical to cupshaped or broadly hemispherical, apically \pm constricted, 4-5-locular, 7-11 mm long, 8-12 mm diam.; calyptra scar raised at c. $45^{\circ}, 1.5-2 \mathrm{~mm}$ wide; stemonophore \pm raised, $0.5-1.0 \mathrm{~mm}$ wide, usually splitting due to greater differential growth in underlying hypanthium; disc flat, ultimately markedly incurved, 2-3 $\mathrm{mm}$ wide; valves narrowly triangular, long-apiculate with persistent style remnants, basally deeply enclosed, apically vertically exserted, to $7 \mathrm{~mm}$ long.

Two subspecies are recognised on differences in pedicel length.

1 Pedicels more than $6 \mathrm{~mm}$ long 26a. subsp. balladoniensis

$1^{*}$ Pedicels $0-2 \mathrm{~mm}$ long 26b. subsp. sedens

\section{6a. Eucalyptus balladoniensis Brooker subsp. balladoniensis}

Mallee to $10 \mathrm{~m}$. Bark persistent for basal $0.5-3 \mathrm{~m}$, then smooth, grey. Adult leaves 7-13 cm long, 13-25 mm wide; petioles to $22 \mathrm{~mm}$ long. Peduncles terete or angular, 9-16 mm long; pedicels terete, 6-9 mm long. Fruits 7-11 mm long, 8-12 mm diam.

In general, the pedicels are longest in the southern part of the subspecies' range.

Distribution: Scattered from Mt Ridley north and east almost to Balladonia (Roe and Coolgardie Districts). Figure 30.

ECoLogy: Locally frequent in mallee woodland, often as an understorey species, on sandy calcareous soils.

Conservation status: Not considered to be at risk.

Selected specimens (from 11 examined): Western Australia (W to E): $7.1 \mathrm{~km} \mathrm{NE}$ of Mt Ridley turnoff on Dempster Road, Hill 2251, Johnson, Blaxell \& Brooker, 5 Nov 1986 (NSW, CANB, CBG, MEL, PERTH); $13 \mathrm{~km}$ SW of Clyde Rock road on Mt Ney road, Hill 2276 E Johnson, 6 Nov 1986 (NSW, CANB, CBG, MEL, PERTH); $28.8 \mathrm{~km}$ NW of Balladonia roadhouse on Highway 1, Hill 708 \& Blaxell, 14 Nov 1983 (NSW, CANB, PERTH).

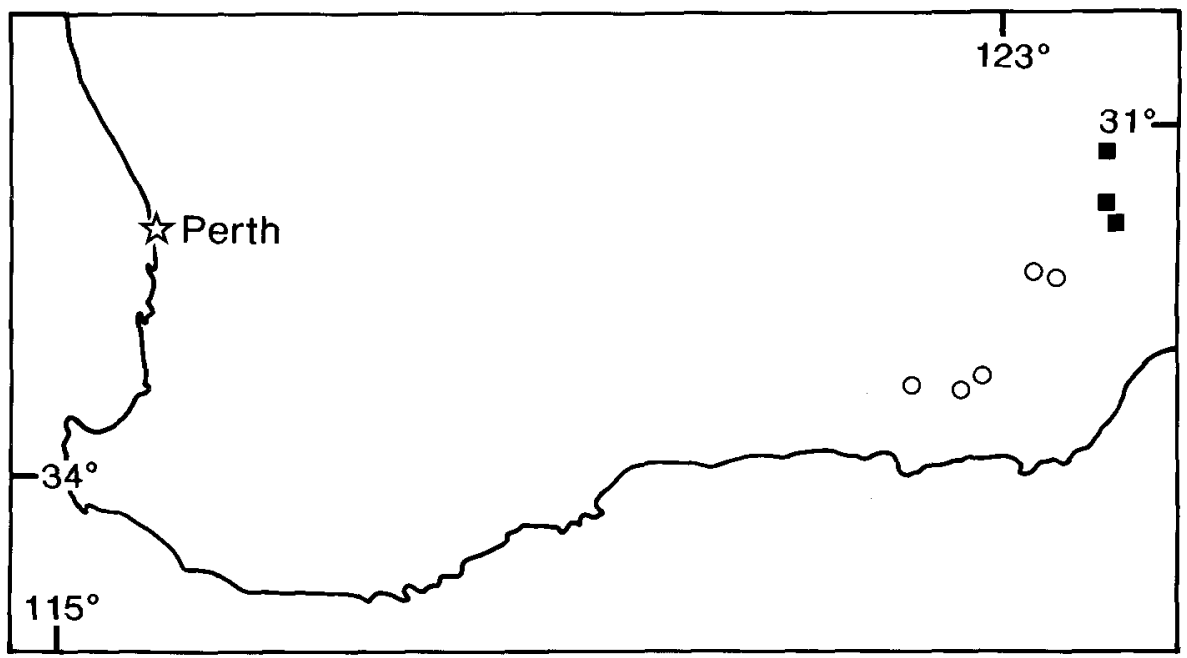

Figure 30. Distribution of E. balladoniensis subsp. balladoniensis (O) and subsp. sedens (ם). 


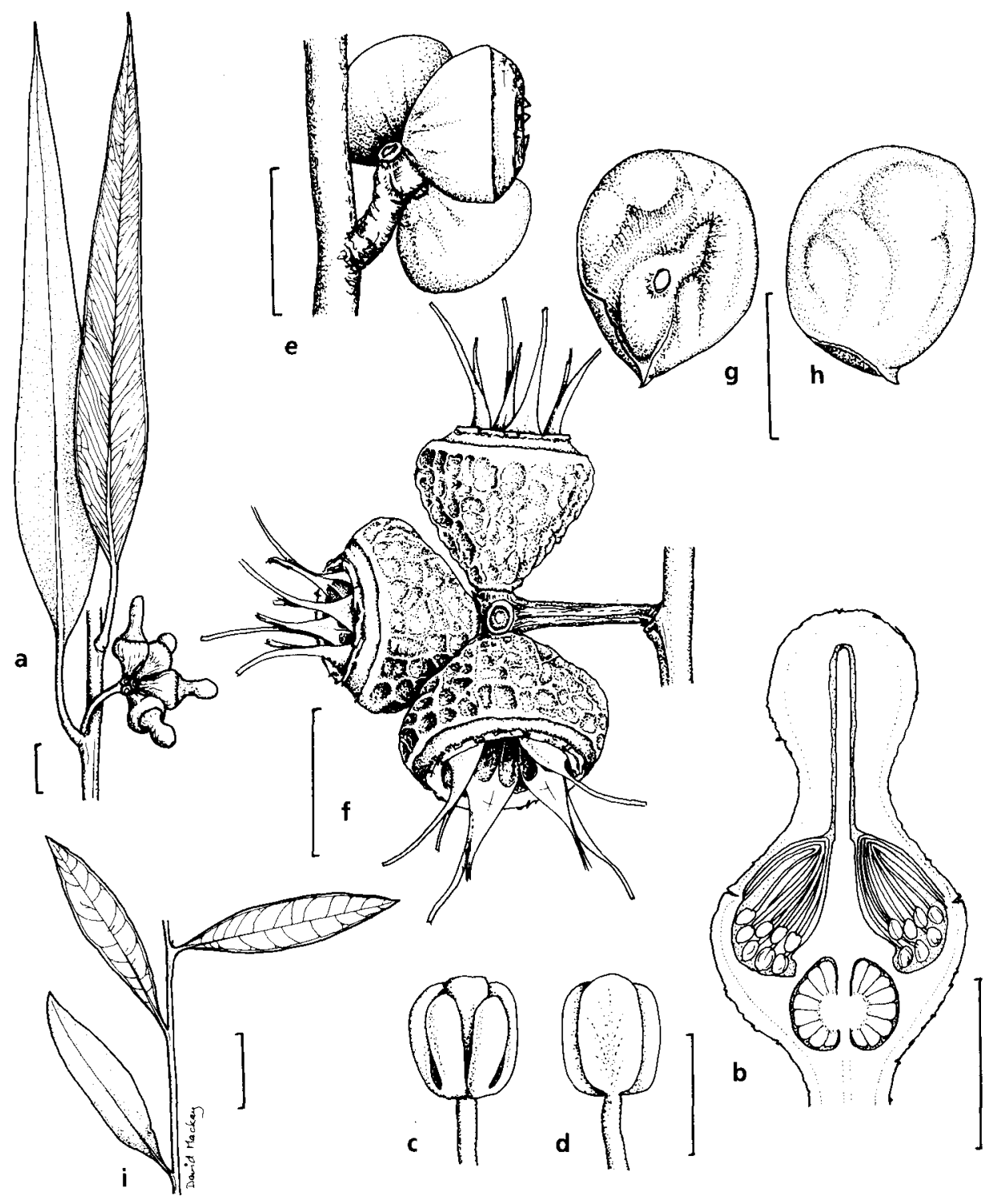

Figure 31. E. balladoniensis subsp. sedens. $\mathbf{a}$, adult leaves and buds; $\mathbf{b}$, section of bud; $\mathbf{c}, \mathbf{d}$, anther; e, f, fruits; $\mathbf{g}$, h, seed; i, juvenile leaves $(\mathrm{a}, \mathrm{b}, \mathrm{c}, \mathrm{d}, \mathrm{g}$, h from Pryor $\mathcal{E}$ Briggs 168, e from Pryor $\mathcal{E}$ Briggs 158, f from Pryor \& Briggs 163). Scale bar: a, e, f, i $=1 \mathrm{~cm} ; \mathrm{b}=5 \mathrm{~mm} ; \mathrm{c}, \mathrm{d}=0.5 \mathrm{~mm}$; $\mathrm{h}=1 \mathrm{~mm}$. 
26b. Eucalyptus balladoniensis Brooker subsp. sedens L. Johnson \& K. Hill, subsp. nov.

Ab subspecie typica alabastris fructibusque subsessilibus et pedunculis crassioribus brevioribusque differt.

Type: Western Australia: $2 \mathrm{~km}$ E of Zanthus then $80.6 \mathrm{~km} \mathrm{~S}$ on track to Balladonia, J.D. Briggs 168 \& L.D. Pryor, 25 Oct 1978 (holo NSW; iso CANB).

Mallee to $6 \mathrm{~m}$. Bark persistent for basal $0.5-1.5 \mathrm{~m}$, then smooth, grey. Adult leaves 7-12 cm long, 1.2-2.4 cm wide; petioles to $19 \mathrm{~mm}$ long. Peduncles thick, angular or \pm flattened, 6-8 mm long; pedicels \pm absent. Fruits $8-11 \mathrm{~mm}$ long, 9-12 mm diam. Figure 31.

Subspecies sedens is distinguished by the subsessile buds and fruits, and the thicker, shorter peduncles.

Subsp. 'sessile fruit' of Brooker \& Kleinig (1990).

Distribution: Known only from a few populations south of Zanthus (Coolgardie District). Figure 30.

ECOLOGY: A component of eucalypt woodland on flat, calcareous red sand country with a variety of species, including E. concinna Maiden \& Blakely, E. flocktoniae (Maiden) Maiden, E. gracilis F. Muell. and E. platycorys Maiden \& Blakely, with a Triodia understorey.

CONSERVATION STATUs: Not considered to be at risk. Although known from a relatively restricted area, this subspecies is likely to be more abundant than is presently known, and occurs in a very remote locality that is secure from disturbance.

The epithet is from the Latin sedens, sitting, referring to the subsessile fruits.

Selected SPECimens (from 4 examined): Western Australia (N to S): $27.9 \mathrm{~km} \mathrm{~S}$ of turnoff E of Zanthus on Balladonia track, Hill $2697 \&$ Johnson, 30 Nov 1986 (NSW), $29 \mathrm{~km}$ S of same turnoff, Pryor \& J. Briggs 158, 24 Oct 1978 (CANB, NSW), $34.8 \mathrm{~km} \mathrm{~S}$ of same turnoff, Pryor \& J. Briggs 163, 24 Oct 1978 (CANB, NSW).

\section{Series Macrocarpae, subseries Leptopodosae}

Species 27 to 29 are placed in series Macrocarpae, which is defined by the combination: pith glands absent; filaments inflexed or irregularly flexed; anthers oblong to ovoid, dorsifixed, versatile, dehiscing by longitudinal slits; seeds ovoid, shallowly reticulately pitted. Within this series, all species discussed here are placed in subseries Leptopodosae, defined by the non-thickened calyptra.

\section{Eucalyptus leptopoda Benth., Fl. Austral. 3: 238 (1867).}

Type CitATIOn: 'W. Australia, Drummond, 5th Coll. Suppl. n. 33 and 36, also n. 151 and 188 of other sets.'

TYPE: Drummond 5th Coll. Suppl. no. 33 (lecto K; isolecto BM, CGE, E, FI, K, KW, LE, MEL, NSW, PERTH, W). Crisp (1982) established lectotypification, although Mueller (1878) had already excluded Drummond 151 and 188 from E. leptopoda, including them in E. salmonophloia F. Muell.

[E. angustifolia Turcz., Bull. Cl. Phys.-Math. Acad. Soc. Sci. Saint-Petersbourg 10: 337 (1852), nom. illegit.; non Desf. ex Link, Enum. Hort. Berol. 2: 30 (1822)]

Mallee to $2.5 \mathrm{~m}$, less commonly a tree to $7 \mathrm{~m}$. Bark smooth, grey, cream or white and pink or brown, shedding in ribbons, sometimes persistent on lower trunk, thick, 
shortly fibrous-flaky. Juvenile leaves disjunct, linear to lanceolate, to $12 \mathrm{~cm}$ long, 10 $\mathrm{mm}$ wide. Adult leaves dull, grey-green, disjunct, similifacial, linear to lanceolate, $5-14 \mathrm{~cm}$ long, 3-17 $\mathrm{mm}$ wide; petioles 3-12 $\mathrm{mm}$ long; lateral veins irregular, at $25-45^{\circ}$ to midrib; intramarginal vein distinct, $0.5-1.5 \mathrm{~mm}$ from margin. Inflorescences simple, axillary; umbellasters 7-11(-15)-flowered; peduncles slender, terete, 5-19 mm long; pedicels slender, terete, 3-11 mm long. Buds conical, 7-11 mm long, 4-6 mm diam.; hypanthium hemispherical, calyptra conical, sometimes rostrate. Stamens all fertile; filaments variously flexed; anthers dorsifixed low on connective gland, versatile, ovoid, dehiscing through short parallel slits. Fruits hemispherical to flattened-globular, 5-8 $\mathrm{mm}$ long, 6-11 $\mathrm{mm}$ diam.; calyptra and stemonophore scars narrow, depressed; disc level to domed; valves 4-5(-6), triangular, acuminate with persistent tips of style, raised. Seeds ovoid, dull, deep red-brown, shallowly pitted; hilum ventral.

Four broadly geographic subspecies are recognised.

1 Disc steeply raised in fruit

2 Adult leaves lanceolate 27b. subsp. elevata

$2^{*}$ Adult leaves linear 27c. subsp. arctata

$1^{*}$ Disc flat or rounded in fruit

3 Inflorescences mostly more than 7-flowered; branchlets pruinose 27a. subsp. leptopoda

$3^{*}$ Inflorescences all or mostly 7-flowered; branchlets not or weakly pruinose 27d. subsp. subluta

\section{7a. Eucalyptus leptopoda Benth. subsp. leptopoda}

Branchlets pruinose. Leaves narrow-lanceolate to lanceolate (broader in the east of the range), 7-13 cm long, 6-12 mm wide; petioles 6-11 mm long. Umbellasters (7-)11(-15)flowered; peduncles $6-17 \mathrm{~mm}$ long; pedicels $4-8 \mathrm{~mm}$ long. Fruits $6-7 \mathrm{~mm}$ long, $7-11$ mm wide; disc flat to slightly domed.

Distinguished by the combination: branchlets pruinose; leaves narrow-lanceolate to lanceolate; umbellasters usually more than 7-flowered, often 11- and sometimes to 15-flowered; pedicels slender; fruits small to medium; disc flat to slightly domed. Figure 32.

Large plants may have a short stocking of persistent bark, but this is not as consistent nor well developed as in the north-western subspecies (below). Plants from the northeast of the range (Bullfinch to Bencubbin, collected near Chiddarcooping) show a strikingly pendulous foliage habit.

Distribution: near Tammin and Kellerberrin east to near Southern Cross, extending south to Marble Rocks and north to Chiddarcooping. Figure 33.

ECOLOGY: Usually occurs as scattered plants in low heath on deep sands.

CONSERVATION STATUS: Not considered to be at risk.

Selected specimens (from 12 examined): Western Australia (W to E): 6.4 miles [10.5 $\mathrm{km}$ ] $\mathrm{N}$ of Bungalla turnoff on highway, Tindale 3716, 26 Aug 1973 (NSW, AD, CANB, K, PERTH); Trayning district, Steedman 1, May 1937 (NSW); Kwelkan, Stoward 148, 4 May 1917 (NSW); 9.5 miles [16 km] E of Merredin, Johnson W 127, 16 Dec 1960 (NSW); 6.8 miles [11 km] E of Carrabin by road, Coveny 8362 \& Habersley, 12 Sep 1976 (NSW, CANB, K, PERTH); firebreak on W side of Chiddarcooping Nature Reserve, Hill 2199, Johnson \& Blaxell, 15 Nov 1986 (NSW, PERTH). 


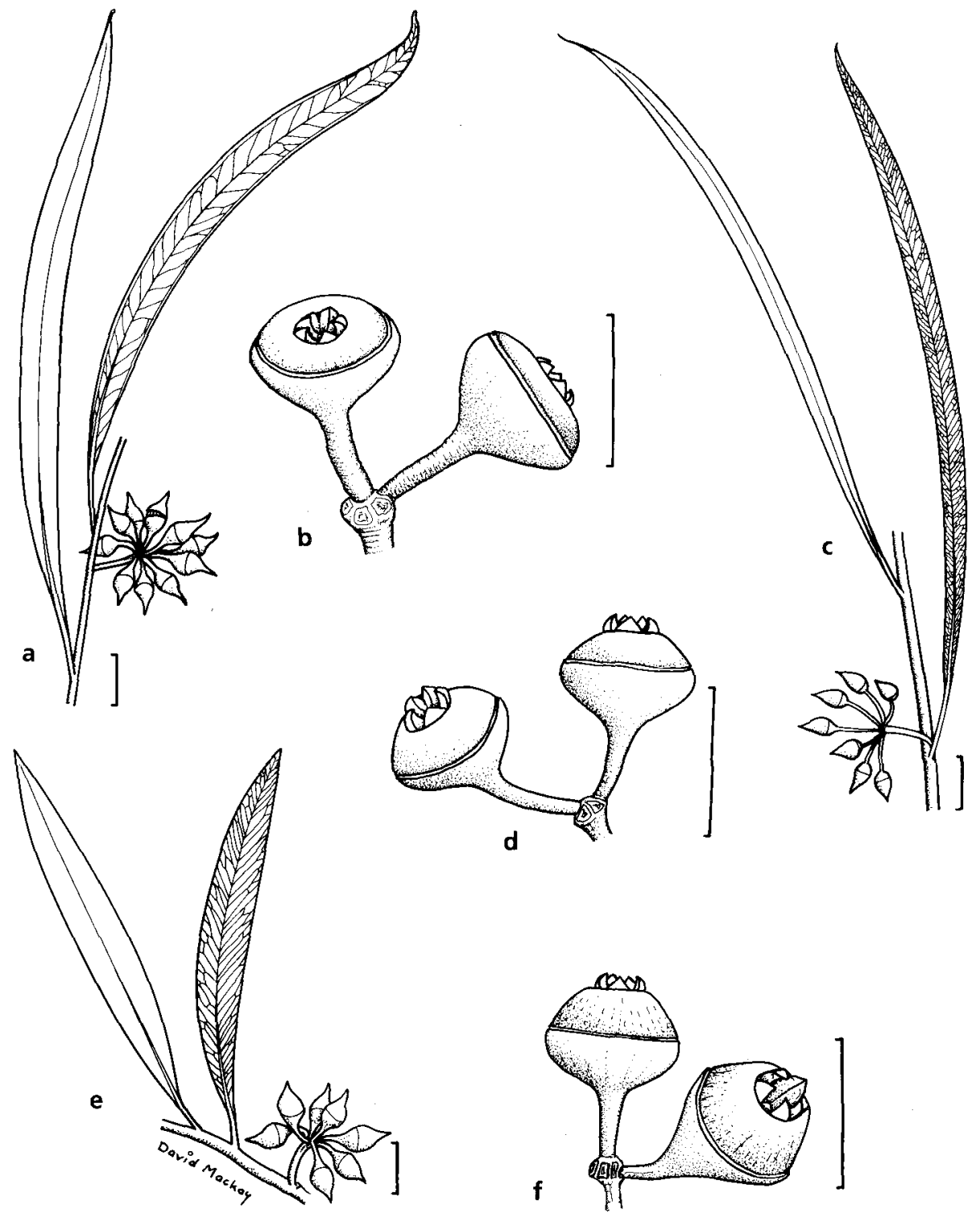

Figure 32. E. leptopoda subsp. leptopoda. a, adult leaves and buds; b, fruits (from Steedman 1, May 1937). E. leptopoda subsp. arctata. c, adult leaves and buds; d, fruits (from Brooker 7922). E. leptopoda subsp. elevata. e, adult leaves and buds; $f$, fruits (from Brooker 7934). Scale bar $=1 \mathrm{~cm}$. 
27b. Eucalyptus leptopoda Benth. subsp. elevata L. Johnson \& K. Hill, sp. nov.

Inter subspecies E. leptopodae combinatione sequenti characterum distinguitur: ramuli non pruinosi; folia lanceolata vel latiora; umbellastrae 7-florae; pedicelli crassi; fructus saepissime mediocres vel magni disco valde elevato.

TYPe: Western Australia: $16 \mathrm{~km}$ from Wiluna - Agnew road on Yeelirrie road, M.I.H. Brooker 9247, 17 Apr 1986 (holo NSW; iso CANB, PERTH).

Branchlets not pruinose. Leaves lanceolate to broad-lanceolate, 6-10 cm long, 8-17 $\mathrm{mm}$ wide; petioles $8-10 \mathrm{~mm}$ long. Umbellasters 7 -flowered; peduncles $7-13 \mathrm{~mm}$ long; pedicels $4-9 \mathrm{~mm}$ long. Fruits $6-8 \mathrm{~mm}$ long, 7-10 $\mathrm{mm}$ wide; disc strongly raised. Figure 32.

Distinguished by the combination: branchlets not pruinose; leaves lanceolate or broader; umbellasters 7-flowered; pedicels thick; fruits medium to large; disc strongly domed.

A stocking of persistent ribbony rough bark is commonly found on the lower trunks in taller individuals, chiefly in the western part of the range. Brooker \& Kleinig (1990: 419) regard these western forms as a separate subspecies (subsp. pachyphitra ined.).

A broad zone of intergradation occurs with subsp. arctata in the region between Mullewa and south of Morawa (Figure 33). Hybridisation is also recorded with E. websteriana subsp. websteriana.

DistRIBUTION: Locally frequent from Yuna to Morawa and, perhaps with a discontinuity, east to Meekatharra and Wiluna and into the desert almost to $127^{\circ} \mathrm{E}$ and south to about $29^{\circ} \mathrm{S}$. Figure 33.

ECOLOGY: A component of shrub heath on red or yellow sandhill country

Conservation Status: Not considered to be at risk.

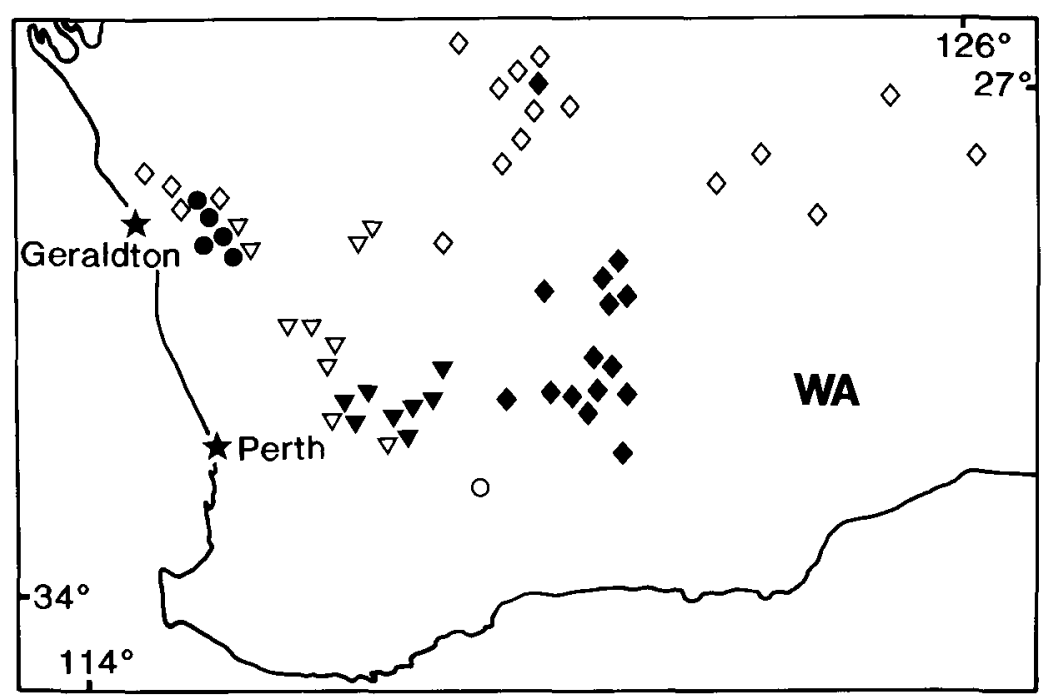

Figure 33. Distribution of E. leptopoda subsp. leptopoda ( $\mathbf{\nabla})$, E. leptopoda subsp. arctata $(\nabla)$, E. leptopoda subsp. elevata $(\diamond)$, E. leptopoda subsp. subluta $(\diamond)$, E. leptopoda subsp. leptopoda - subsp. subluta intergrade $(O)$ and E. leptopoda subsp. arctata - subsp. elevata intergrades (๑). 
Selected SPECIMENS (from 25 examined): Western Australia ( $W$ to E): Horan Road, $5.7 \mathrm{~km} \mathrm{~N}$ of Ogilvie East Road (28 $\left.07^{\prime} \mathrm{S} 114^{\circ} 48^{\prime} \mathrm{E}\right)$, Brooker 9934, 9935, 20 Apr 1988 (CANB, NSW, PERTH); $9.5 \mathrm{~km}$ N of Yuna road on Wandara road, Brooker 7934, 25 Jan 1983 (CANB, NSW, PERTH); 9.4 miles [16 km] W of Pindar, Chippendale 48, 20 Oct 1966 (CANB, NSW); $47.0 \mathrm{~km} \mathrm{~S}$ of Youanmi on Bullfinch road, Hill $2602 \mathcal{E}$ Johnson, 25 Nov 1986 (NSW); $64.5 \mathrm{~km}$ E of Meekatharra on Wiluna road, Hill 507, Johnson, Blaxell \& Brooker, 2 Nov 1983 (NSW, CANB, PERTH); $67 \mathrm{~km}$ from Wiluna-Agnew road on Sandstone road, Brooker 8650, 30 Aug 1984 (CANB, NSW, PERTH); $91.3 \mathrm{~km}$ W of Wiluna - Agnew road on Sandstone road, Brooker 8706, 17 Oct 1984 (CANB, NSW, PERTH); W of Sandstone road, S of Wiluna, Speck 858, 20 Sep 1957 (CANB, NSW); $2.4 \mathrm{~km} \mathrm{~N}$ of Albion Downs turnoff on Leonora - Wiluna road, Hill 516, Johnson, Blaxell \& Brooker, 3 Nov 1983 (NSW, AD, BRI, CANB, K, MEL, MO, PERTH); $21 \mathrm{~km} \mathrm{E} \mathrm{of} \mathrm{Cosmo} \mathrm{Newbery,} \mathrm{Brooker} \mathrm{8536,} 9$ May 1984 (CANB, NSW, PERTH); $242 \mathrm{~km}$ S of Warburton towards Neale Junction, Brooker 8559, 11 May 1984 (CANB, NSW, PERTH).

27c. Eucalyptus leptopoda Benth. subsp. arctata L. Johnson \& K. Hill, subsp. nov.

Inter subspecies E. leptopodae combinatione sequenti characterum distinguitur: ramuli non pruinosi; folia linearia vel anguste linearia, erecta; umbellastra 7-flora; pedicelli graciles; fructus parvi vel mediocres, disco modice elevato vel aliquando planato.

Type: Western Australia: $20 \mathrm{~km}$ E of Dalwallinu towards Kulja, M.I.H. Brooker 7922, 12 Jan 1983 (holo NSW; iso CANB, PERTH).

Branchlets not pruinose. Leaves linear to narrow-lanceolate, erect, $7-14 \mathrm{~cm}$ long, 3-8 $\mathrm{mm}$ wide; petioles 3-7 mm long. Umbellasters 7 -flowered; peduncles $5-9 \mathrm{~mm}$ long; pedicels 3-11 mm long. Fruits 5-8 $\mathrm{mm}$ long, 6-10 mm wide; disc moderately to strongly domed. Figure 32.

Distinguished by the combination: branchlets not pruinose; leaves linear, erect; umbellasters 7-flowered; pedicels slender; fruits small to medium; disc moderately to strongly domed.

Larger individuals usually show a stocking of persistent bark on the lower trunk, as do western occurrences of subsp. elevata (above). The two subspecies also intergrade over a broad zone (above).

Although recent collections of this subspecies are from near Cadoux northwards, two older collections indicate an overlap with subsp. leptopoda. If these are indeed partly sympatric, the taxonomic rank will require reconsideration. Recent search by one of us (L.J.) in the Merredin-Bruce Rock area has not confirmed the two early vaguely specified collections cited below.

Distribution: From Koolanooka to Tammin and perhaps south of Merredin, northeast to Paynes Find. Figure 33.

CONSERVATION STATUS: Not considered to be at risk.

The epithet is from the Latin arctatus, narrowed, in reference to the narrow leaves.

Selected SPECIMENS (from 11 examined): Western Australia (W to E): $4.7 \mathrm{~km}$ N of Gutha-Wurarga road on McWhirter Road, Hill 2579 \& Johnson, 23 Nov 1986 (NSW, PERTH); 44 km NNE of Paynes Find, Brooker 8713, 18 Oct 1984 (CANB, NSW); rabbit fence 60 miles [100 km] E of Watheroo, Koch 1609, 1611, Oct 1905 (NSW); $10.9 \mathrm{~km} \mathrm{~W}$ of Koorda on Cadoux road, Hill 2503, Johnson \& Blaxell, 16 Nov 1986 (NSW, PERTH); Tammin, Maiden, Oct 1909 (NSW); Bruce Rock, Stoward 19, Sep 1916 (NSW).

27d. Eucalyptus leptopoda Benth. subsp. subluta L. Johnson \& K. Hill, subsp. nov.

Inter subspecies E. leptopodae combinatione sequenti characterum distinguitur: ramuli saepissime non vel leviter pruinosi; folia linearia vel anguste linearia, erecti; umbellastrae saepissime 7-florae; pedicelli graciles; fructus parvi vel mediocres, disco planato. 
Type: Western Australia: $37 \mathrm{~km}$ SE of Coolgardie, M.I.H. Brooker 7048, 9 Nov 1981 (holo NSW; iso CANB, PERTH).

Branchlets usually weakly or not pruinose. Leaves linear to lanceolate, 5-9 $\mathrm{cm}$ long, 6-12 mm wide; petioles 10-12 mm long. Umbellasters usually 7-flowered (rarely some with more flowers); peduncles $8-10 \mathrm{~mm}$ long; pedicels $4-6 \mathrm{~mm}$ long. Fruits $5-7 \mathrm{~mm}$ long, 7-10 mm wide; disc flat to slightly domed.

Distinguished by the combination: branchlets weakly or not pruinose; leaves linear to lanceolate, erect; umbellasters usually 7-flowered; pedicels slender; fruits small to medium; disc flattened.

Distribution: Apart from an apparent outlier sympatric with subsp. elevata south of Wiluna, this subspecies occupies the south-east of the range of the species, from somewhat north of Menzies to north-east of Norseman. Figure 33.

Some intergradation occurs with subsp. leptopoda where the ranges meet.

CONSERvation STATUS: Not considered to be at risk.

The epithet is from the Latin sublutus, washed beneath, referring to the usually slighter degree of pruinosity of the branchlets, in contrast to those of subsp. leptopoda.

Selected specimens (from 22 examined): Western Australia ( $\mathrm{N}$ to $\mathrm{S}$ ): $16 \mathrm{~km}$ from Wiluna - Agnew road on Yeelirrie road, Brooker 9248, 17 Apr 1986 (CANB, NSW, PERTH); $36 \mathrm{~km} \mathrm{~N}$ of Menzies towards Leonora, Hill 532, Johnson, Blaxell \& Brooker, 4 Nov 1983 (NSW, AD, CANB, PERTH); 4.2 miles [6 km] N of Menzies towards Leonora, Baker 91, 8 Nov 1970 (CANB, NSW); 20 miles [32 km] W of Riverina homestead, Beard 6514, 11 Sep 1973 (PERTH, NSW); Comet Vale, Maiden, Sep-Nov 1909 (NSW); 0.4 km E of gate, Goongarrie Nat. Reserve, Brooker 9606, 9607, 9608, 9609, 6 May 1987 (CANB, NSW, PERTH); 60.3 miles [100 km] W of Coolgardie on highway, Tindale 59 \& Bennett, 9 Mar 1970 (NSW);66 km SSW of Coolgardie on road to Queen Victoria Rock, Crisp 5603, 31 Jan 1979 (CBG, NSW, PERTH); $39.1 \mathrm{~km}$ W of Coolgardie - Norseman road on Hyden road, Hill 2852, 25 Aug 1988 (NSW).

Subsp. arctata - subsp. elevata intergrades (from 8 examined): $5.6 \mathrm{~km}$ S of Geraldton-Mullewa road on Mingenew road, Hill 2574 \& Johnson, 23 Nov 1986 (NSW, PERTH); 8.5 miles [15 km] S of Morawa, Chippendale 55, 20 Oct 1966 (CANB, NSW).

Subsp. leptopoda - subsp. subluta intergrades: c. $50 \mathrm{~km}$ E of Hyden, $1 \mathrm{~km} \mathrm{~N}$ of Marble Rocks, Crisp 5549, 29 Jan 1979 (CBG, CANB, NSW, PERTH).

E. leptopoda subsp. elevata $\times$ E. websteriana subsp. websteriana: $91 \mathrm{~km} \mathrm{NW}$ of airstrip SE of Lake Rason ( $28^{\circ} 54^{\prime}$ S $\left.124^{\circ} 29^{\prime} \mathrm{E}\right)$, Brooker 8574, 13 May 1984 (CANB, NSW, PERTH).

\section{Eucalyptus synandra Crisp, Nuytsia 4(1): 129 (1982).}

TYPe citation: 'Typus: $\pm 5 \mathrm{~km}$ S of Jingymia, 30³1'S, 117 $25^{\prime} \mathrm{E}, 2$ Jan. 1981, A.S. George 16203, fl., fr., photo, spirit material (holo: PERTH; iso : CBG, FRI [now CANB], K, NSW, PERTH).'

Mallee to $5 \mathrm{~m}$. Bark smooth, powdery white over pink and brown, shedding in ribbons. Juvenile leaves opposite, lanceolate for about 4 nodes, becoming linear, disjunct, to 8 $\mathrm{cm}$ long, $3 \mathrm{~mm}$ wide. Adult crown thin, pendulous. Adult leaves dull, grey-green, disjunct, similifacial, linear to narrow-lanceolate, 6-18 $\mathrm{cm}$ long, $6-15 \mathrm{~mm}$ wide; petioles $3-15 \mathrm{~mm}$ long; lateral veins irregular, at $25-45^{\circ}$ to midrib; intramarginal vein distinct, $0.5-1.5 \mathrm{~mm}$ from margin. Inflorescences simple, axillary; umbellasters 7-flowered; peduncles slender, terete, 9-18 mm long; pedicels slender, terete, 7-16 mm long. Buds conical, 16-24 mm long, 7-8 mm diam.; hypanthium shallowly hemispherical to saucer-shaped, calyptra conical, attenuate. Stamens all fertile; filaments variously flexed, cream to pink, united for lower half into a tube; anthers dorsifixed, versatile, ovoid, 
dehiscing through short parallel slits. Fruits hemispherical to flattened-globular, 6-9 $\mathrm{mm}$ long, 9-13 mm diam.; calyptra and stemonophore scars narrow, depressed; disc domed; valves triangular, acuminate with persistent tips of style, raised. Seeds ovoid, dull, deep red-brown, shallowly pitted; hilum ventral.

E. synandra is described here under a reduced circumscription to allow comparison with the segregate taxon described below. Both taxa are distinguished within the subseries by the partially coherent filaments. The related $E$. beardiana also has partially coherent filaments, and can be distinguished by the elongate cup-shaped hypanthium in bud and fruit, and the longer fruits (9-11 $\mathrm{mm}$ long).

Distribution: A rare and localised species of the northeastern Wheat Belt, from near Morawa to near Koorda. Figure 34.

ECOLOGY: This species occurs mostly on shallow sandy soils over gravelly or lateritic rises, in open mallee shrubland with few other eucalypt species.

CONSERVATION STATUS: 3R-. This species is highly localised in distribution, and occurs in country potentially threatened by agricultural activities.

Selected specimens (from 8 examined): Western Australia (W to E): $3.5 \mathrm{~km} \mathrm{~N}$ of Gutha-Wurarga road on McWhirter Road, Hill 2577 \& Johnson, 23 Nov 1986 (NSW, CANB, CBG, MEL, PERTH); $27 \mathrm{~km}$ from Bimbijy Road on Emu Fence Road, Hill 2515, Johnson \& Blaxell, 16 Nov 1986 (NSW, CANB, CBG, MEL, PERTH).

\section{Eucalyptus rosacea L. Johnson $\mathcal{E} K$ K. Hill, sp. nov.}

Affinis E. synandrae sed characteribus sequentibus distinguitur: folia adulta minora, haud pendula; discus minus elevatus; cortex griseus vel roseus.

TyPE: Western Australia: $12.0 \mathrm{~km} S$ of Queen Victoria Spring on Cundeelee road, K.D. Hill 2686 E L.A.S. Johnson, 30 Nov 1986 (holo NSW; iso CANB, CBG, MEL, PERTH).

[E. elachyphylla Brooker \& Kleinig, Field Guide Eucalypts 2: 419 (1990); nom. illegit.]

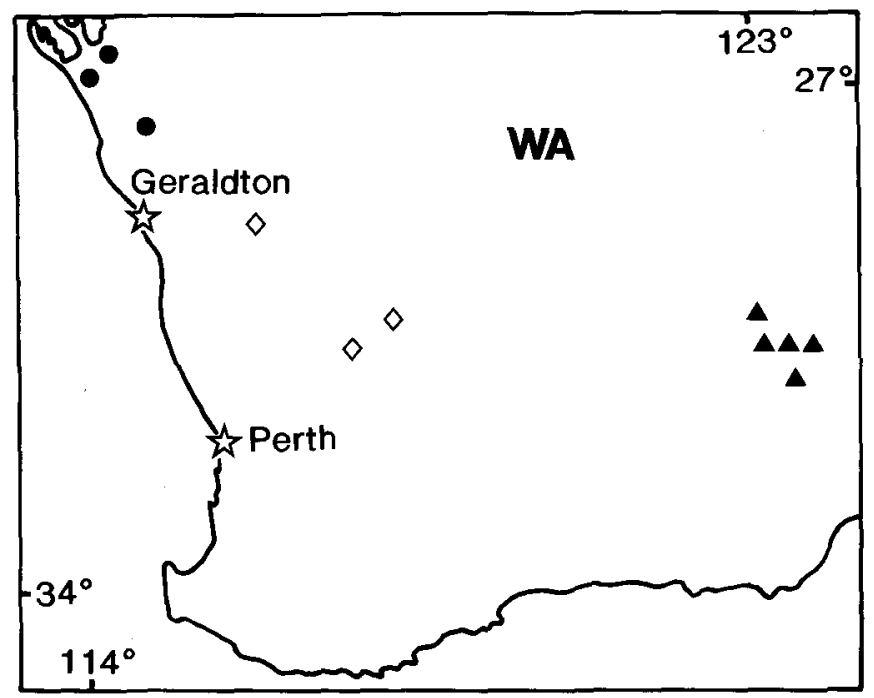

Figure 34. E. beardiana $(\bullet)$, E. synandra $(\diamond)$ and E. rosacea $(\bullet)$. 


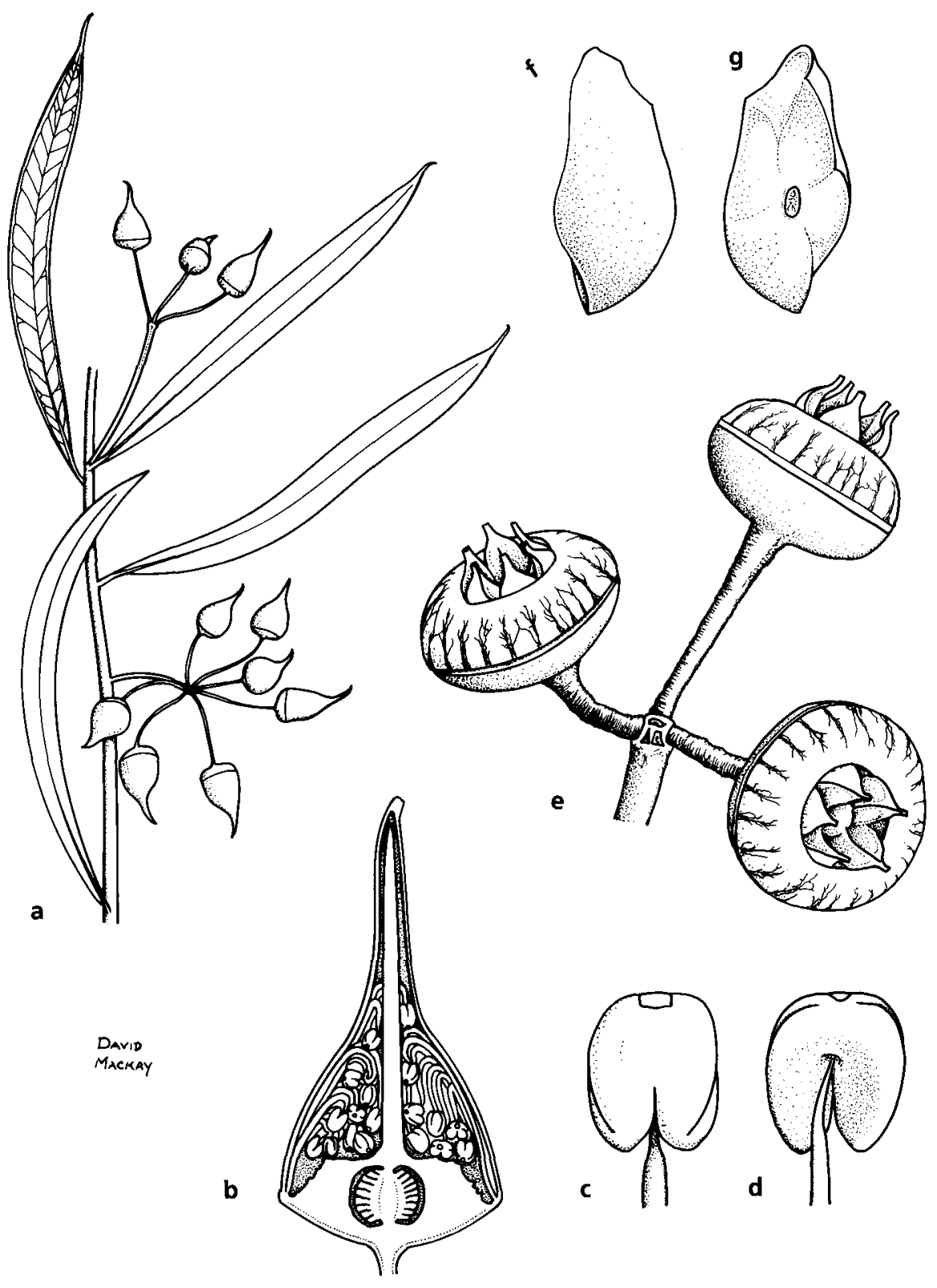

Figure 35. E. rosacea. $\mathbf{a}$, adult leaves and buds; $\mathbf{b}$, section of bud; $\mathbf{c}, \mathbf{d}$, anther; $\mathbf{e}$, fruits; $\mathbf{f}, \mathbf{g}$, seed (all from MacFarlane 1127 \& Bedford). Scale bar: $\mathrm{a}=1 \mathrm{~cm} ; \mathrm{b}, \mathrm{e}=5 \mathrm{~mm} ; \mathrm{c}, \mathrm{d}, \mathrm{f}, \mathrm{g}=0.5 \mathrm{~mm}$. 
Mallee to $2.5 \mathrm{~m}$. Bark smooth, grey, white and pink, shedding in ribbons. Juvenile leaves opposite, lanceolate for about 6 nodes, becoming linear, disjunct, to $8 \mathrm{~cm}$ long, $3 \mathrm{~mm}$ wide. Adult leaves dull, grey-green, disjunct, similifacial, linear to narrow-lanceolate, 6-12 cm long, 6-10 mm wide; petioles 3-10 mm long; lateral veins irregular, at $25-45^{\circ}$ to midrib; intramarginal vein distinct, $0.5-1.5 \mathrm{~mm}$ from margin. Inflorescences simple, axillary; umbellasters 3-7-flowered; peduncles slender, terete, 10-20 mm long; pedicels slender, terete, 9-16 mm long. Buds conical, $16-20 \mathrm{~mm}$ long, 7-8 mm diam.; hypanthium shallowly hemispherical to saucer-shaped, calyptra conical, attenuate. Stamens all fertile; filaments variously flexed, cream or pink to red, united for lower half into a tube; anthers dorsifixed, versatile, ovoid, dehiscing through short parallel slits. Fruits hemispherical to flattened-globular, 6-9 mm long, 9-13 mm diam.; calyptra and stemonophore scars narrow, depressed; disc slightly raised to domed; valves triangular, acuminate with persistent tips of style, raised. Seeds ovoid, dull, deep redbrown, shallowly pitted; hilum ventral. Figure 35.

Distinguished from E. synandra (with which it shares the partially united stamen filaments) by the mostly smaller, non-pendulous adult leaves, the less raised disc, and the grey or pink bark (rather than powdery white).

Distribution: Known from the south-western fringes of the Great Victoria Desert. Figure 34.

ECOLOGY: Locally frequent to dominant in low open mallee shrubland on shallow aeolian sands over siliceous substrates.

CONSERvation STAtus: At least locally, and probably more widely, abundant in a remote area - not considered to be at risk.

The epithet is from the Latin rosaceus, rosy, referring to the frequently pink flowers and pinkish bark.

Selected spectmens (from 6 examined): Western Australia (W to E): $33.7 \mathrm{~km}$ E of Pinjin on PNC road, Hill 2667 \& Johnson, 29 Nov 1986 (NSW); $12.2 \mathrm{~km} \mathrm{~S}$ of Queen Victoria Spring on Cundeelee road, Macfarlane 1127 \& Bedford, 2 Dec 1982 (PERTH, NSW); $1.3 \mathrm{~km} \mathrm{~N}$ of Zanthus, Hill 2693 \& Johnson, 30 Nov 1986 (NSW).

\section{Series Orbifoliae}

Species 30 to 33 are placed in series Orbifoliae, defined by the combination: pith glands absent; bark longitudinally splitting and peeling ('minniritchi' bark, see Brooker \& Kleinig 1990); filaments inflexed or irregularly flexed; anthers ovoid, dorsifixed, versatile, dehiscing by short slits; seeds ovoid, shallowly reticulately pitted. The following four species constitute superspecies Orbifolia, defined by the obovate, rounded to retuse adult leaves. The early juvenile leaves are lanceolate to ovate, quickly becoming orbicular, and becoming retuse only at a later ontogenetic stage. This suggests that the retuse adult leaves are not merely neotenous (cf. Brooker \& Kleinig 1990: 279). The group consists of small isolated occurrences on rocky sites, and minor differences often exist between populations. However, the populations group into consistent assemblages mostly over large total areas, and four species are distinguishable (Figure 37). 


\section{Key to the species of superspecies Orbifolia}

1 Calyptra rounded

2 Fruits more than $7 \mathrm{~mm}$ long; branchlets strongly pruinose; buds and fruits strongly pruinose

33. E. orbifolia

2* Fruits less than $7 \mathrm{~mm}$ long; branchlets, buds and fruits weakly or not pruinose 30. E. websteriana

1* Calyptra conical

3 Calyptra more than 3 times longer than hypanthium; leaves mostly longer than broad

31. E. educta

$3^{*}$ Calyptra less than 2.5 times longer than hypanthium; leaves broader than long

32. E. lata

30. Eucalyptus websteriana Maiden, J. \& Proc. Roy. Soc. New South Wales 49: 313 (1915).

TYPE CITATION: 'Habitat - Near Coolgardie, Western Australia associated with E. torquata Luehmann. (Mr. now Dr. C.L. Webster).'

TYPe: Western Australia: Coolgardie, L.C. Webster, 1900 (lecto NSW, here designated). Three specimens in NSW, collected by Webster from Coolgardie in 1898 (forwarded by C. Walter), 1899 and 1900 may be regarded as syntypes. All three have 'Type' labels affixed by Blakely. However, the 1900 collection is the most comprehensive of the three and we therefore designate it the Lectotype. The collector was wrongly cited as 'C.L. Webster' in the protologue.

Mallee to $3 \mathrm{~m}$, of twisted and spreading habit. Bark red-brown, splitting longitudinally and peeling partly back to reveal green to brown smooth bark ('minniritchi' bark). Branchlets weakly or not pruinose. Juvenile leaves disjunct, petiolate, ovate to orbicular. Adult leaves disjunct, dull, grey-green, obovate to orbicular, retuse or rounded, $1.5-4.0 \mathrm{~cm}$ long, $15-30 \mathrm{~mm}$ wide; petioles $10-15 \mathrm{~mm}$ long; lateral veins regular, moderately spaced, at $40-50^{\circ}$ to midrib; intramarginal vein distinct, more or less looped, 1-3 mm from margin; oil glands angular. Inflorescences simple, axillary; umbellasters 7-flowered; peduncles 8-17 mm long; pedicels 3-8 mm long. Buds globular to ovoid, 5-8 $\mathrm{mm}$ long, 5-6 mm diam.; calyptra hemispherical, as long as hypanthium or slightly longer. Stamens all fertile; filaments slender, irregularly flexed; anthers ovoid, dorsifixed near base of connective gland, versatile, dehiscing through lateral pores. Fruits hemispherical to flattened hemispherical, 5-8 mm long, 8-11(-13) $\mathrm{mm}$ diam.; calyptra and stemonophore scars raised at c. $45^{\circ}$; disc flat to slightly raised, 2.5-3.5 mm wide. Seeds grey-brown, ovoid, shallowly regularly pitted; chaff red-brown.

Distinguished within the superspecies Orbifolia by the following combination of characters: adult leaves longer than broad, rounded or retuse; pedicels medium to long ( $>3 \mathrm{~mm}$ long); calyptra hemispherical; fruits small to medium $(<11 \mathrm{~mm} \mathrm{diam}$.); disc slightly swollen; hypanthium bowl-shaped.

Two geographic subspecies are recognised.

1 Branchlets, buds and fruits distinctly pruinose (except when much weathered); pedicels mostly $>5 \mathrm{~mm}$ long 30a. subsp. websteriana

$1^{*}$ Branchlets and buds not pruinose except in very young stages; pedicels mostly $<6 \mathrm{~mm}$ long 30b. subsp. norsemanica 


\section{0a. Eucalyptus websteriana Maiden subsp. websteriana}

Branches, buds and fruits (except when old) distinctly pruinose. Adult leaves broad (l:b = 1-1.5:1), retuse or rounded, $1.5-4.0 \mathrm{~cm}$ long, $15-30 \mathrm{~mm}$ wide; petioles $8-15 \mathrm{~mm}$ long. Pedicels $5-8 \mathrm{~mm}$ long. Figure 36.

Hybrids are recorded with E. leptopoda subsp. elevata (cited under the latter).

Distribution: Sporadic but locally frequent from Coolgardie and Kambalda east to Plumridge Lakes. Figure 37.

ECOLOGY: Found in scleromorphic shrublands on shallow soil on rocky rises.

Conservation status: 3R. Scattered and localised, although probably not under immediate threat.

Selected specimens (from 12 examined): Western Australia ( $W$ to E): Comet Hill, $11.9 \mathrm{~km} S$ ofCoolgardie, Hill 2633 \& Johnson, 26 Nov 1986 (NSW, PERTH); Red Hill, Kambalda, Coveny 8430 $\mathcal{E}$ Habersley, 14 Sep 1976 (NSW, BRI, CANB, K, L, MEL, PERTH); E slope of Yowie Hill on Pinjin road, Hill 2663 \& Johnson, 29 Nov 1986 (NSW, PERTH); SE of Lake Rason (28 ${ }^{\circ} 54^{\prime}$ S $124^{\circ} 29^{\prime}$ E), Brooker 8576, 13 May 1984 (CANB, NSW, PERTH).

30b. Eucalyptus websteriana Maiden subsp. norsemanica L. Johnson $\mathcal{E}$ K. Hill, subsp. nov.

Ab subspecie typica ramulis alabastris et fructibus maturis non pruinosis, foliis adultis aliquanto angustioribus retusisque et petiolis pedicellisque brevibus differt.

TyPe: Western Australia: 5.5 miles [8.5 km] N of Norseman, L.A.S. Johnson W 176, 18 Dec 1960 (holo NSW 53307; iso PERTH).

Mature branchlets, buds and fruits not pruinose. Adult leaves narrowish, mostly retuse, $2.2-4.0 \mathrm{~cm}$ long, $14-21 \mathrm{~mm}$ wide; petioles $7-11 \mathrm{~mm}$ long. Pedicels $3-6 \mathrm{~mm}$ long. Figure 36.

Distinguished from subsp. websteriana by the non-pruinose mature branchlets, buds and fruits, the somewhat narrower, retuse adult leaves, and the often shorter petioles and pedicels.

DistRIBUTION: Known from a single stand on skeletal soil on a granite outcrop north of Norseman, but an isolated population near Widgiemooltha shows intermediate characters (see below). Figure 37.

CONSERVATION STATUS: $2 \mathrm{~V}$-. Known only from the type locality, which is possibly at risk from mineral exploration and mining activities.

The epithet refers to the town of Norseman, near the type locality.

Selected specimens (from 7 examined): WeStern Australia: $8 \mathrm{~km} \mathrm{~N}$ of Norseman, Hill 591, Johnson, Blaxell, Brooker \& Hopper, 6 Nov 1983 (NSW); 5.7 miles [9.1 km] N of Norseman, Brooker 4537, 11 Apr 1974 (CANB, NSW, PERTH).

Intergrades, subsp. websteriana - subsp. norsemanica: Lake Lefroy, Larsen, Sep 1920 (NSW).

31. Eucalyptus educta $L$. Johnson $\mathcal{E} K$. Hill, sp. nov.

Inter species affinitatis $E$. orbifoliae calyptra longa conicaque distinguitur.

TyPe: Western Australia: The Dromedaries, north of Beacon, M.I.H. Brooker 8436, 25 Jan 1984 (holo NSW; iso AD, CANB, MEL, PERTH). 


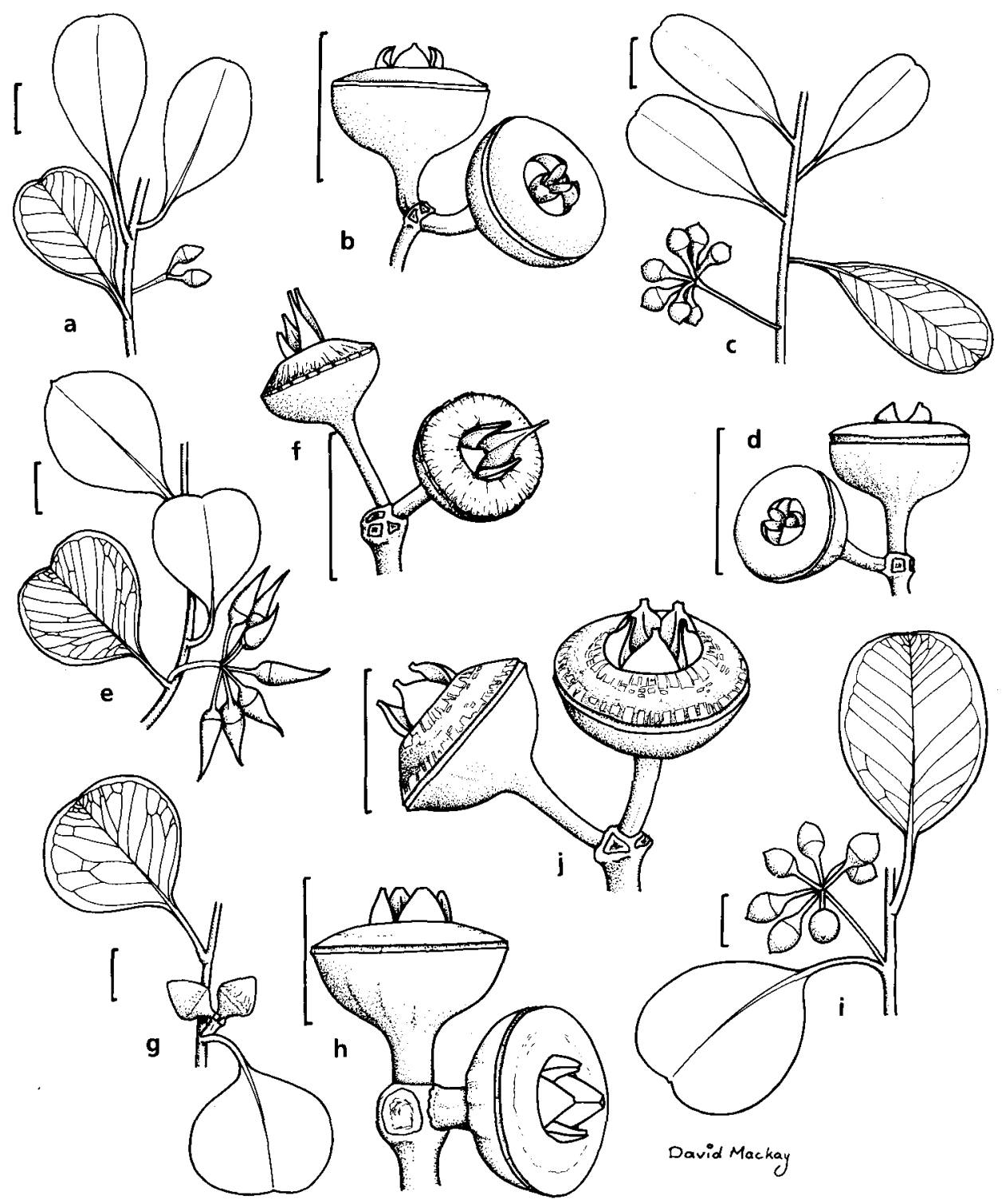

Figure 36. E. websteriana subsp. websteriana. a, adult leaves and buds; b, fruits (from Coveny 8430 $\mathcal{E}$ Habersley). E. websteriana subsp. norsemanica. $\mathbf{c}$, adult leaves and buds; $\mathbf{d}$, fruits (c from Brooker 4537, d, from NSW 53307). E. educta. e, adult leaves and buds; f, fruits (e from Brooker 8494, $\mathbf{f}$ from Brooker 8436). E. lata. $g$, adult leaves and buds; $\mathbf{h}$, fruits ( $\mathrm{g}$ from Cooper, June 1923, $\mathbf{h}$ from Fraser, 24 Feb 1922). E. orbifolia. i, adult leaves and buds; $j$, fruits (from Brooker 5114). Scale bars $=1 \mathrm{~cm}$. 
Mallee to $3 \mathrm{~m}$, of twisted and spreading habit. Bark red-brown, splitting longitudinally and peeling partly back to reveal green to brown smooth bark ('minniritchi'). Branchlets glaucous. Juvenile leaves disjunct, petiolate, ovate to orbicular. Adult leaves disjunct, dull, grey-green to strongly glaucous, obovate to orbicular, usually rounded (mostly not retuse), 2.0-4.0 cm long, 15-30 mm wide; petioles 5-8 mm long; lateral veins regular, moderately spaced, at $40-50^{\circ}$ to midrib; intramarginal vein distinct, more or less looped, 1-3 mm from margin; oil glands angular. Inflorescences simple, axillary; umbellasters 7-flowered; peduncles 9-14 $\mathrm{mm}$ long; pedicels 6-8 $\mathrm{mm}$ long. Buds ovoid to fusiform, 15-18 mm long, 5-6 mm diam.; calyptra elongate-conical, more than 3 times as long as hypanthium. Stamens all fertile; filaments slender, irregularly flexed and erect; anthers ovoid, dorsifixed near base of connective gland, versatile, dehiscing through lateral pores. Fruits hemispherical to flattened hemispherical, 6-7 mm long, 9-10 mm diam.; calyptra and stemonophore scars raised at c. $45^{\circ}$; disc flat to slightly raised, $2.5-3.5 \mathrm{~mm}$ wide. Seeds grey-brown, ovoid, shallowly regularly pitted; chaff red-brown. Figure 36.

Distinguished within the E. orbifolia group by the long, conical calyptra, and longer leaves.

Distribution: Known only from The Dromedaries. Figure 37.

ECOLOGY: Restricted to scleromorphic shrubland on shallow gritty sand over granite.

Conservation status: $2 \mathrm{R}-$. Known only from the type locality, which is in a remote and relatively undisturbed area.

The epithet is from the Latin eductus, drawn out, referring to the long calyptra.

Stecimens eXAMINED: Western Australia: Gillian Rock, N of Beacon, Hill 2512, Johnson \& Blaxell, 16 Nov 1986 (NSW, PERTH); Brooker 8494, 16 Mar 1984 (CANB, NSW, PERTH).

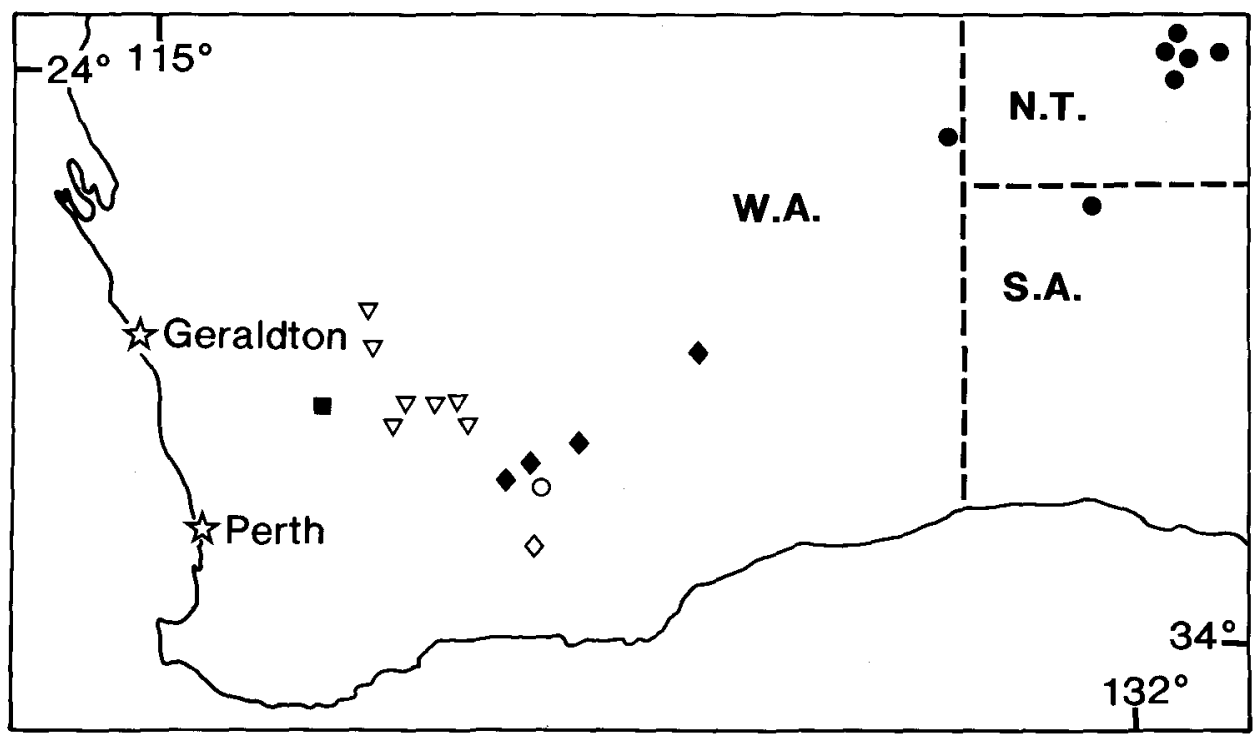

Figure 37. Distribution of E. websteriana subsp. websteriana $(\diamond)$, subsp. norsemanica $(\diamond)$, subsp. websteriana - subsp. norsemanica intergrades $(\bigcirc)$, E. lata $(\nabla)$, E. educta $(\square)$ and E. orbifolia $(\bullet)$. 


\section{Eucalyptus lata L. Johnson \& K. Hill, sp. nov.}

Inter species affinitatis $E$. orbifoliae combinatione sequenti characterum distinguitur: folia adulta lata, pedicelli breves, calyptra breviter conica, et fructus magni.

TYPe: Western Australia: $13.6 \mathrm{~km}$ W of Callion on Mussons Soak road, K.D. Hill 2658 $\mathcal{E}$ L.A.S. Johnson, 28 Nov 1986 (holo NSW; iso CANB, CBG, MEL, PERTH).

Mallee to $3 \mathrm{~m}$, of twisted and spreading habit. Bark red-brown, splitting longitudinally and peeling partly back to reveal green to brown smooth bark ('minniritchi' bark). Branchlets strongly glaucous. Juvenile leaves disjunct, petiolate, ovate to orbicular. Adult leaves disjunct, dull, grey-green, orbicular, regularly retuse, 2.5-5.0 $\mathrm{cm}$ long, 25-50 mm wide; petioles $8-27 \mathrm{~mm}$ long; lateral veins regular, moderately spaced, at $40-50^{\circ}$ to midrib; intramarginal vein distinct, more or less looped, $1-4 \mathrm{~mm}$ from margin; oil glands angular. Inflorescences simple, axillary; umbellasters 7-flowered; peduncles 5-29 mm long; pedicels 3-6 mm long. Buds ovoid, 10-12 mm long, 8-9 mm diam.; calyptra broadly conical, 1.5-2.5 times as long as hypanthium. Stamens all fertile; filaments slender, irregularly flexed and erect; anthers ovoid, dorsifixed near base of connective gland, versatile, dehiscing through lateral pores. Fruits flattened obconical, 7-9 mm long, 13-15 mm diam.; calyptra and stemonophore scars raised at c. $45^{\circ}$; disc flat, 3-5 mm wide. Seeds grey-brown, ovoid, shallowly regularly pitted; chaff red-brown. Figure 36.

Distinguished within the E. orbifolia group by the broad adult leaves with medium to long petioles, the shortly conical calyptra, and the large fruits with short, thick pedicels.

Distribution: Sporadic and localised, from near Youanmi to the Die Hardy Range, and east to near Callion. Figure 37.

ECOLOGY: Restricted to scleromorphic shrublands on shallow sandy soil over granite rocks

CONSERVATION STATUS: Although populations are highly localised, the species is widely scattered over relatively undisturbed country, and not considered to be at risk.

The epithet is from the Latin latus, broad, referring to the leaves and fruits.

SELECTED SPECIMENS (from 9 examined): Western Australia (W to E): $23.0 \mathrm{~km} \mathrm{SW}$ of Youanmi on Paynes Find road, Hill 2594 \& Johnson, 24 Nov 1986 (NSW, PERTH); Mt Jackson to Lake Barlee, Fraser, 24 Feb 1922 (NSW); Pigeon Rock, 89.7 miles [143 km] N of Bullfinch, Chippendale 358, 21 Mar 1968 (CANB, NSW); 3.5-4 miles [5.6-6.4 km] W of Lake Giles, Cooper, 27 June 1923 (NSW); Hospital Rock, 30 miles [50 km] W of Riverina, Beard 6519, 11 Sep 1973 (PERTH, NSW).

\section{Eucalyptus orbifolia F. Muell., Fragm. 5: 50 (1865).}

TYPE CITATION: 'Ad bases montium graniticorum Novae Hollandiae austro-occidentalis interioris, longitudine $119^{\circ} 25^{\prime}$, latitudine $30^{\circ} 47^{\prime}$. C. Harper.'

TYPE: holo MEL; iso K.

Mallee to $3 \mathrm{~m}$, of twisted and spreading habit. Bark red-brown, splitting longitudinally and peeling partly back to reveal green to brown smooth bark ('minniritchi' bark). Branchlets strongly glaucous. Juvenile leaves disjunct, petiolate, ovate to orbicular, later ones retuse. Adult leaves disjunct, dull, strongly glaucous, obovate to orbicular, usually longer than broad, regularly retuse, $2.0-4.5 \mathrm{~cm}$ long, $15-40 \mathrm{~mm}$ wide; petioles $6-16 \mathrm{~mm}$ long; lateral veins regular, moderately spaced, at $40-50^{\circ}$ to midrib; intramarginal vein distinct, more or less looped, 1-3 mm from margin; oil glands angular. Inflorescences simple, axillary; umbellasters 7-flowered or rarely 3-flowered; peduncles 8-20 mm long; pedicels 4-10 mm long. Buds globular to ovoid, 
8-10 $\mathrm{mm}$ long, 6-8 $\mathrm{mm}$ diam.; calyptra hemispherical, as long as hypanthium or slightly longer. Stamens all fertile; filaments slender, irregularly flexed; anthers ovoid, dorsifixed near base of connective gland, versatile, dehiscing through lateral pores. Fruits hemispherical to flattened hemispherical, 7-9 mm long, 8-13 mm diam.; calyptra and stemonophore scars raised at $c .45^{\circ}$; disc flat to slightly raised, 3-4 mm wide. Seeds grey-brown, ovoid, shallowly regularly pitted; chaff red-brown. Figure 36.

E. orbifolia is described here under a reduced circumscription to allow comparison with segregate taxa described above.

DistRiBution: Sporadic but locally frequent, in ranges of Central Australia; recorded from the Dean Range (Western Australia), Musgrave Range (South Australia) and MacDonnell Range (Northern Territory). Figure 37.

ECOLOGY: Restricted to shallow or skeletal sandy soils on the higher slopes of sandstone ranges.

Hybrids are recorded with E. sessilis (Maiden) Blakely.

CONSERVATION STATUS: Widely scattered over relatively undisturbed country, not considered to be at risk.

Selected specimens (from 12 examined): Western Australia: $S$ end of Dean Range, Carolin 6106, 2 Aug 1967 (NSW). South AustRaliA: upper slopes of Mt Woodroffe, Symon 2693, 11 Aug 1962 (AD, NSW). Northern Territory (W to E): Mt Sonder, Dunlop 2513, 20 Apr 1972 (DNA, NSW); track to Palm Valley No. 2 gas well, on crest of Krichauff Ra. W of Mt Hermannsburg, Hill 865, 866, Johnson \& Benson, 11 July 1984 (NSW), Brooker 5114, 5 Apr 1976 (CANB, NSW, PERTH); Serpentine Gorge, Maconochie 1063, 1 July 1970 (DNA, NSW).

E. orbifolia x E. sessilis: Northern Territory: Palm Valley No. 2 gas well, on crest of Krichauff Ra W of Mt Hermannsburg, Hill 867, Johnson \& Benson, 11 July 1984 (NSW); Serpentine Gorge, Maconochie 1065, 1 July 1970 (DNA, NSW).

\section{Acknowledgments}

Our colleague in the overall project, Don Blaxell, has contributed helpful discussions on many points and has been involved in the recognition of several of the taxa. Particular thanks are due to Leonie Stanberg, who has provided invaluable assistance through the project and drafted the distribution maps. David Mackay prepared most of the illustrations, and Bob Roden prepared the illustration of E. mannensis subsp. vespertina. Lani Retter provided much assistance in earlier stages of the investigations. The work was in part supported by grants from the Australian Biological Resources Study and the Royal Botanic Gardens and Domain Trust, which are gratefully acknowledged. A grant from the Royal Botanic Gardens and National Herbarium Research Fund to one of us (LJ) to defray field expenses is also gratefully acknowledged. Dr Surrey Jacobs is thanked for critically reading and commenting on the manuscript. We are grateful to Ian Brooker for useful critical comments. 


\section{References}

Bentham, G. (1867) Flora Australiensis, vol. 3 (L. Reeve: London).

Blakely, W.F. (1934) A Key to the Eucalypts (The Worker Trustees: Sydney).

Briggs, J.D. \& Leigh, J.H. (1988) Rare or Threatened Australian Plants. Australian National Parks and Wildlife Service, Special Publication 14.

Brooker, M.I.H. \& Hopper, S.D. (1991) A taxonomic revision of Eucalyptus wandoo, E. redunca and allied species (Eucalyptus series Levispermae Maiden - Myrtaceae) in Western Australia. Nuytsia 8(1): 1-189.

Brooker, M.I.H. \& Kleinig, D.A. (1990) Field Guide to Eucalypts vol 2. (Inkata: Melbourne).

Chippendale, G.M. (1973) Eucalypts of the Western Australian goldfields (Australian Government Publishing Service: Canberra).

Chippendale, G.M. (1988) Eucalyptus, Angophora. In A.S. George (ed.), Flora of Australia, vol. 19 (Australian Government Publishing Service: Canberra).

Crisp, M.D. (1982) Eucalyptus synandra (Myrtaceae), a new species of mallee from Western Australia. Nuytsia 4(1): 129-134.

Diels, L. \& E. Pritzel (1905) Fragmenta phytographiae Australiae occidentalis. Bot. Jahrb. Syst. 35: 55-662.

Gardner, C.A. (1960) Trees of Western Australia. J. Agric. Western Australia 4th series 1(7): 643653.

Hall, N. \& Johnston, R.D. (1964) A card key for the identification of eucalypts (Forestry \& Timber Bureau: Canberra)

Johnson, L.A.S. (1972) Evolution and classification in Eucalyptus. Proc. Linn. Soc. New South Wales 97: 11-29.

Johnson, L.A.S. \& Briggs, B.G. (1984) Myrtales and Myrtaceae - a phylogenetic analysis. Ann. Missouri Bot. Gard. 71: 700-756.

Johnson, L.A.S. \& Hill, K.D. (1990) New taxa and combinations in Eucalyptus (Myrtaceae). Telopea 4(1): 37-108.

Johnson, L.A.S. \& Hill, K.D. (1991) Systematic studies in the eucalypts 2. A revision of the gimlets and related species, Eucalyptus extracodical series Salubres and Annulatae (Myrtaceae). Telopea 4(2): 201-222.

Ladiges, P.Y. (1984) A comparative study of trichomes in Angophora Cav. and Eucalyptus L'Hérit. Austral. J. Bot. 32: 561-574

Luehmann, J.G. (1898) A short dichotomous key to the hitherto known species of Eucalyptus. Proc. Austral. Assoc. Adv. Sci. 7: 523-536.

Maiden, J.H. (1903-33) A Critical Revision of the Genus Eucalyptus (Govt. Printer: Sydney).

McVaugh, R. (1968) The Genera of American Myrtaceae - an interim report. Taxon 17: 354-418.

Mueller, F. (1878) Fragmenta phytographiae Australiae 11: 11-12 (Govt. Printer: Melbourne)

Pryor, L.D. \& Johnson, L.A.S. (1971) A Classification of the Eucalypts (ANU Press: Canberra). 


\section{Index}

New names and combinations are printed in boldface; synonyms are printed in italics.

Eucalyptus section Bisectaria 562

Eucalyptus series Accedentes 563

series Astringentes 572

series Cneorifoliae 591

series Erythronemae 575

series Falcatae 603

series Loxophlebae 563

series Macrocarpae 617

series Occidentales 572

series Orbifoliae 625

Eucalyptus subgenus Symphyomyrtus 562

Eucalyptus subseries Leptopodosae 617

subseries Occidentalosae 572

Eucalyptus superspecies Orbifolia 625

Eucalyptus accedens 563

E. amygdalina 567

E. angustifolia 617

E. angustissima 597

subsp. angustissima 597

subsp. quaerenda 598

E. argyphea 603

E. aspratilis 572

E. balanites 591

E. balanopelex 605

E. balladoniensis 614

subsp. balladoniensis 615

subsp. sedens 617

E. beardiana 623

E. blaxellii 564

E. corrugata 612

E. decipiens 591

E. depauperata 587
E. educta 627

E. elachyphylla 623

E. eremophila 584

var. grandiflora 572

E. erythronema var. roei 587

E. falcata 603

E. foecunda var. loxophleba 565

E. foliosa 595

E. goniantha 609

subsp. goniantha 609

subsp. notactites 610

subsp. semiglobosa 608

E. goniantha 612

E. goniocarpa 582

E. gratiae 571

E. grossa 585

E. incerata 585

E. incrassata var. goniantha 609

E. jutsonii 599

E. kessellii 612

subsp. eugnosta 613

subsp. kessellii 612

E. kruseana 571

E. lata 630

E. leptopoda 617

subsp. arctata 621

subsp. elevata 620

subsp. leptopoda 618

subsp. subluta 621 
E. loxophleba 565

subsp. lissophloia 569

subsp: loxophleba 567

subsp. supralaevis 568

subsp. gratiae 571

var. fruticosa 568

E. mannensis 599

subsp. mannensis 599

subsp. vespertina 600

E. misella 593

E. occidentalis 573

var. eremophila 584

var. grandiflora 572

var. stenantha 572

E. orbifolia 630

E. ornata 604

E. phylacis 591

E. pruiniramis 563

E. recta 604

E. rosacea 623
E. sargentii 573

subsp. sargentii 574

subsp. fallens 575

E. semiglobosa 608

E. sessilis 631

E. spathulata 575

subsp. grandiflora 580

var. grandiflora 580

E. suggrandis 580

subsp. alipes 581

subsp. suggrandis 581

E. synandra 622

E. tenera 586

E. tephroclada 586

E. vegrandis 577

E. wandoo 568

E. websteriana 626

subsp. norsemanica 627

subsp. websteriana 627

E. xanthonema 579

Manuscript received 5 December 1990

Manuscript accepted 5 June 1991 